Andrews University

Digital Commons @ Andrews University

2010

\title{
A Paradigm for Cell Church Ministry in the Seventh-day Adventist Church in South Korea
}

Won Moo Song

Andrews University

Follow this and additional works at: https://digitalcommons.andrews.edu/dmin

Part of the Missions and World Christianity Commons, and the Practical Theology Commons

\section{Recommended Citation}

Song, Won Moo, "A Paradigm for Cell Church Ministry in the Seventh-day Adventist Church in South Korea" (2010). Professional Dissertations DMin. 124.

https://dx.doi.org/10.32597/dmin/124

https://digitalcommons.andrews.edu/dmin/124

This Project Report is brought to you for free and open access by the Graduate Research at Digital Commons @ Andrews University. It has been accepted for inclusion in Professional Dissertations DMin by an authorized administrator of Digital Commons @ Andrews University. For more information, please contact repository@andrews.edu. 


\section{ABSTRACT}

A PARADIGM FOR CELL CHURCH MINISTRY IN

THE SEVENTH-DAY ADVENTIST CHURCH

IN SOUTH KOREA

by

Won Moo Song

Adviser: Donald C. James 


\section{ABSTRACT OF GRADUATE STUDENT RESEARCH \\ Project Dissertation}

Andrew's University

Seventh-day Adventist Theological Seminary

Title: A PARADIGM FOR CELL CHURCH MINISTRY

IN THE SEVENTH-DAY ADVENTIST

CHURCH IN SOUTH KOREA

Name of researcher: Won Moo Song

Name and degree of faculty adviser: Donald C. James. DMin

Date completed: July 2010

\section{Problem}

Small group ministry. known as the cell church. was thought to be the best response to the slow growth of membership in the Seventh-day Adventist (SDA) Church in South Korea. However. the attempt to develop effective cell church ministries has failed to attract new. or even current. members. Yet. there are three non-SDA churches that have had success in setting up model cell churches. The purpose of this study is to explore possible reasons for the failure. examine the successful programs, and identify those steps the Korean Adventist church could adopt in order to establish a positive paradigm for cell church ministry. 
Method

This is a comparative-descriptive study. The main task is to determine the qualities that characterize the SDA Church in South Korea as compared to three nonSDA churches with model cell church systems. One part is to understand the general ideas of the cell church system and its biblical background. The writings of Ellen $\mathrm{G}$. White are also explored. Field research is utilized to examine a practical profile of cell group ministry as it is practiced by the three model cell churches. An attempt is also made to research the basic system of the Korean Seventh-day Adventist (KSDA) churches. Based on the results. the two systems (SDA and non-SDA with cell systems) are compared to find distinctive characteristics that the SDA church system could emulate. Through the comparison and biblical study. a paradigm of cell church ministry is suggested.

\section{Conclusion}

Cell church ministry must be a very effective tool for evangelism in the modern society of Korea. However, there are many barriers and hindrances to SDA success with cell church ministry. even though non-SDA churches had success with the system. To have success in cell church strategy. KSDA churches must innovate to build a new strategy of a cell church to fit SDA churches. The findings of this study should be applied into a new paradigm shift for SDA churches in Korea. Further studies must be continued to develop a practical plan and strategy of cell church ministry for the SDA church environment in the future. 


\author{
Andrews University \\ Seventh-day Adventist Theological Seminary
}

\title{
A PARADIGM FOR CELL CHURCH MINISTRY IN THE SEVENTH-DAY ADVENTIST CHURCH IN SOUTH KOREA
}

\author{
A Project Dissertation \\ Presented in Partial Fulfillment \\ of the Requirements for the Degree \\ Doctor of Ministry
}

by

Won Moo Song

July 2010 
C Copyright by Won Moo Song 2010

All Rights Reserved 


\title{
A PARADIGM FOR CELL CHURCH MINISTRY IN \\ THE SEVENTH-DAY ADVENTIST CHURCH \\ IN SOUTH KOREA
}

\author{
A dissertation \\ presented in partial fulfillment \\ of the requirements for the degree \\ Doctor of Ministry
}

by

Won Moo Song

APPROVAL BY THE COMMITTEE:
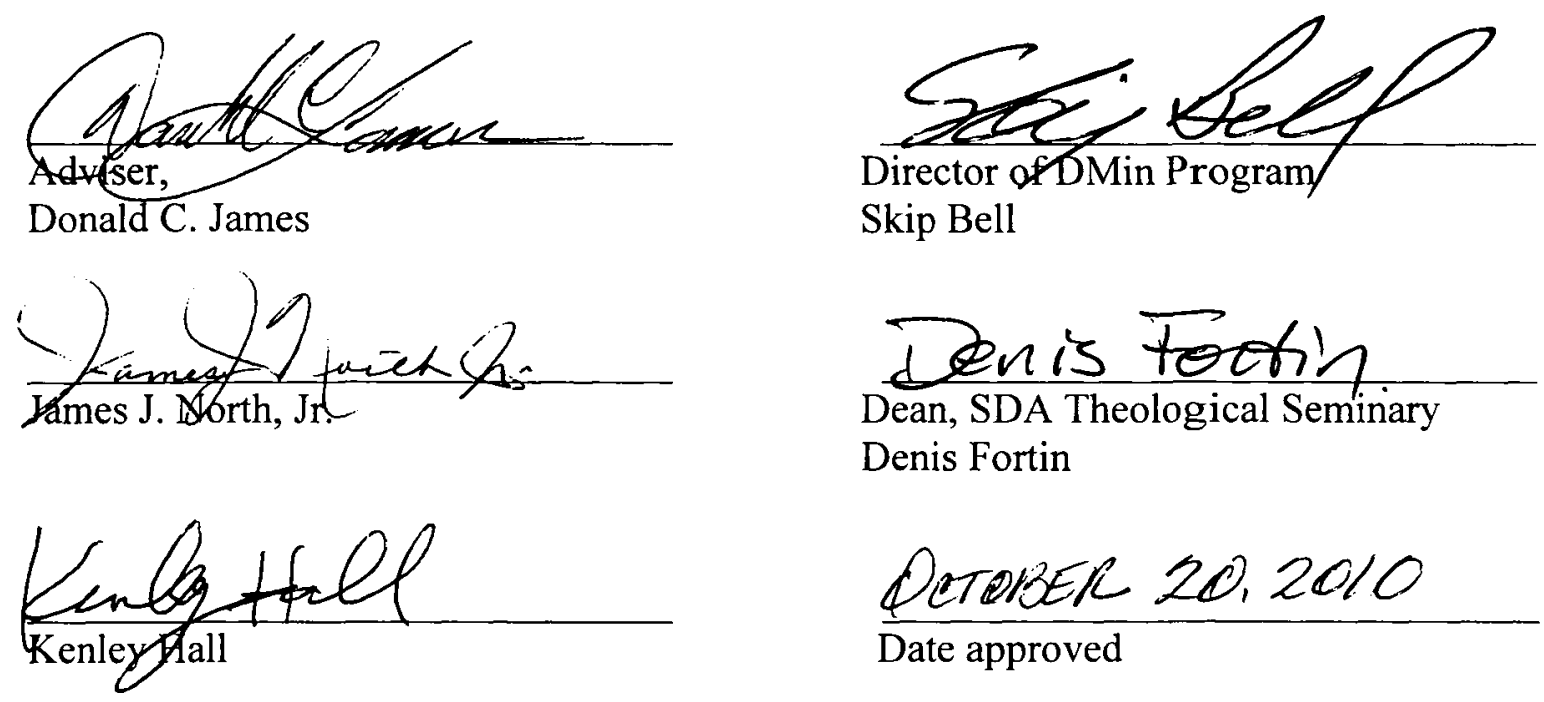

Denis Fortin

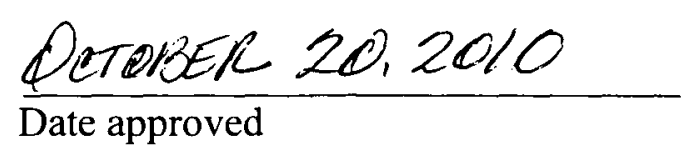




\section{TABLE OF CONTENTS}

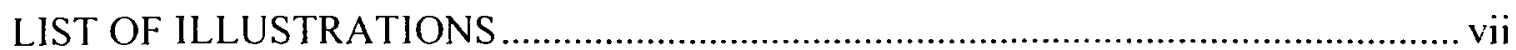

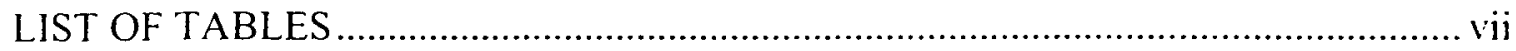

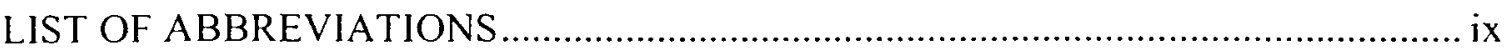

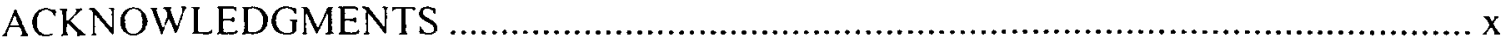

Chapter

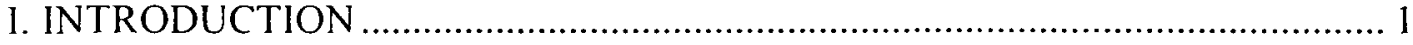

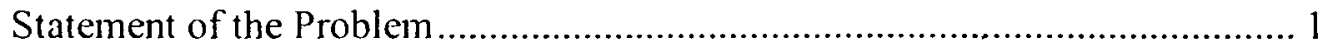

Purpose of the Dissertation ......................................................................... 2

Justification for the Dissertation ................................................................. 2

Delimitations of the Dissertation .................................................................. 2

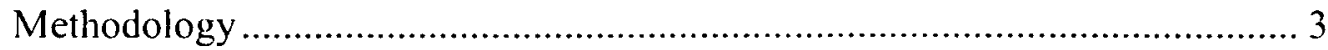

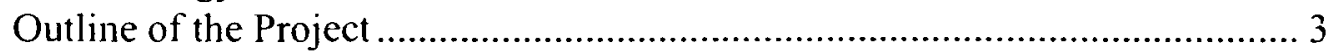

Expectations of the Dissertation ................................................................... 4

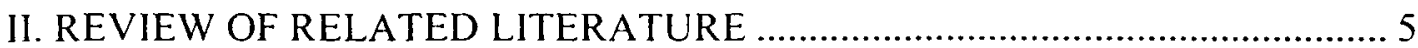

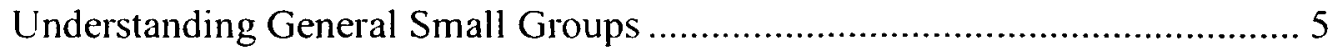

Defining Cell Church Ministry ................................................................... 7

Distinctive Characteristics of Cell Group Ministry ....................................... 8

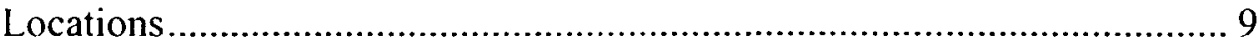

Multiplication of Cell Groups............................................................ 10

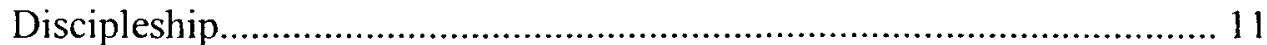

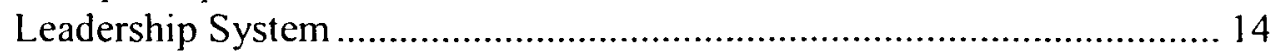

Basic Models of Cell Group Structure .................................................. 19

Basic Tools and Materials for Cell Group Ministry ................................. 22

Meeting Practice of the Cell Group Ministry ............................................ 25

The Strengths and Weaknesses of the Cell Church System .......................... 28

The Strengths of the Cell Church System .................................................. 28

The Weaknesses of the Cell Church System .......................................... 30 
Small Groups in Biblical Perspective ......................................................... 32

Possible Prototype Cell Group Community at Creation .................................. 32

The Early Small Group as a Cell Group ……………….................................. 35

The Small Group Church that Jesus Initiated .......................................... 35

Small Church Grouping as a Strategy for the Early Church...................... 37

Essential Elements of the Small Group Church in the Early Times......... 38

Oikos/Family of God ........................................................................ 38

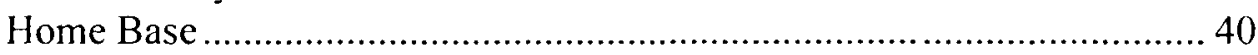

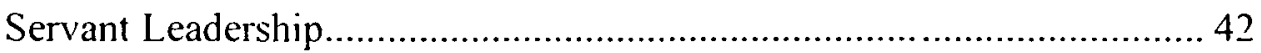

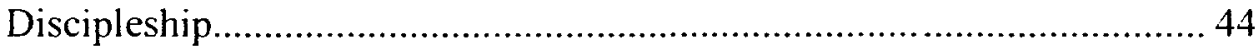

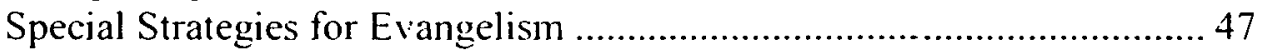

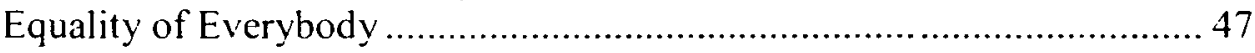

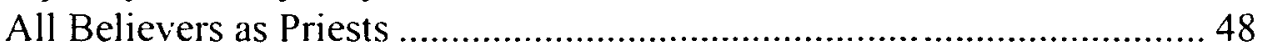

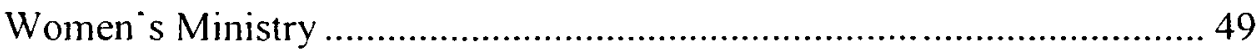

Powerful Ceremonies of Christ.................................................................. 52

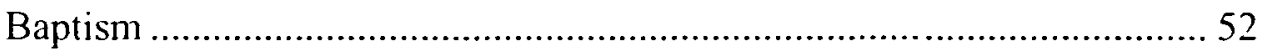

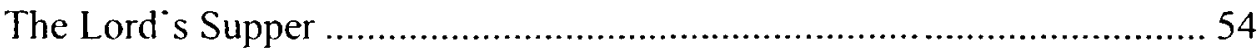

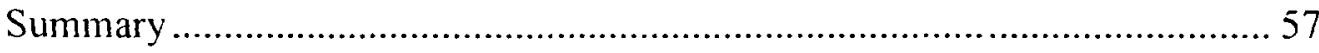

IV. UNDERSTANDING OF CELL CHURCH MINISTRY FROM

THE WRITINGS OF ELLEN G. WHITE........................................................ 58

Small Group Ministry and Ellen G. White ................................................. 58

Early Influence of Home-Based Meetings.............................................. 58

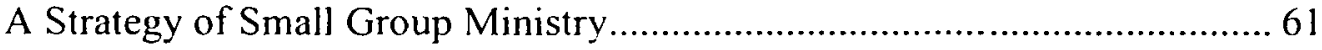

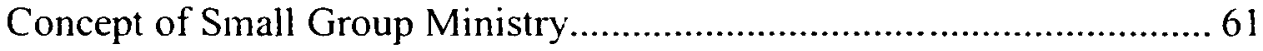

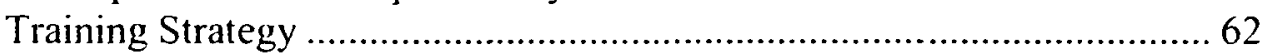

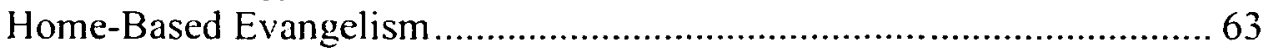

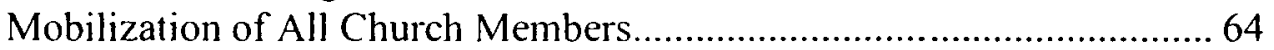

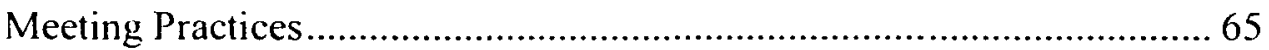

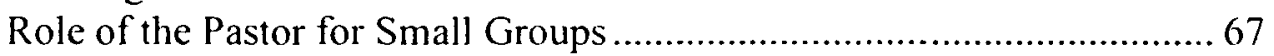

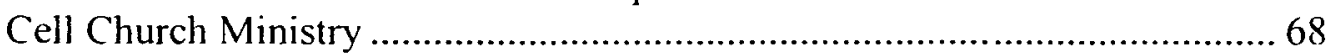

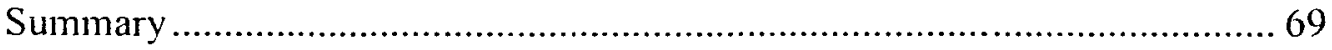

V. CONTEXTUAL BACKGROUND OF KOREA _............................................. 70

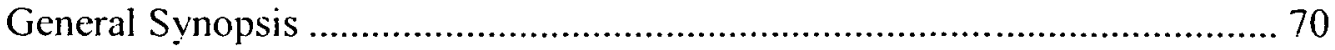

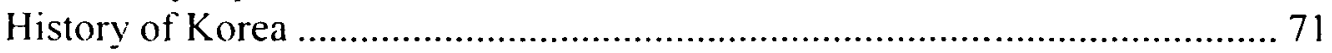

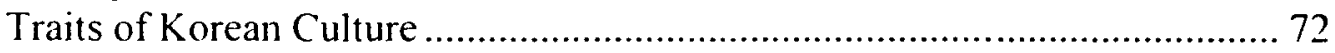

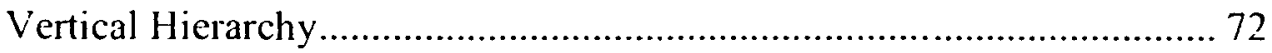

Religious Background ..................................................................... 73

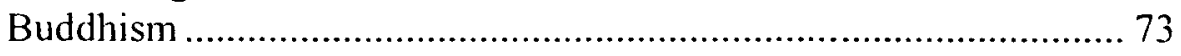

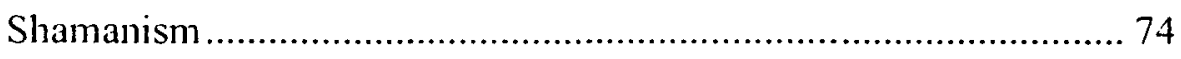

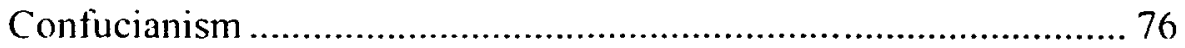




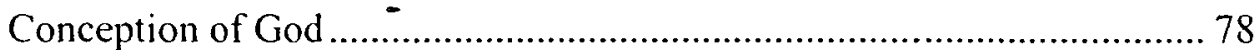

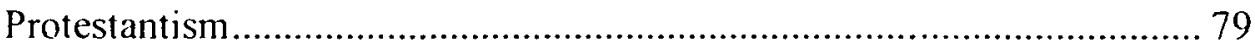

Summary

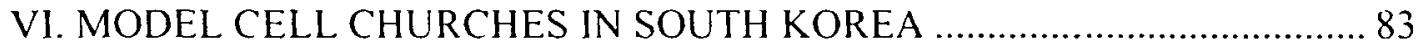

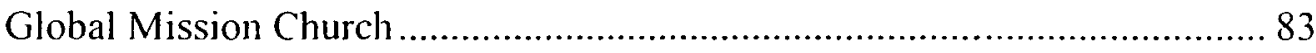

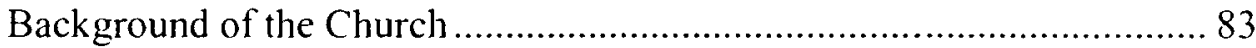

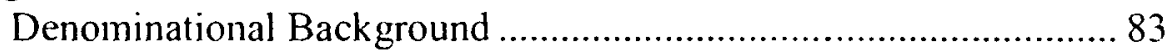

Brief History of the Church Growth .............................................. 84

Cell Strategy of the Global Mission Church ..................................... 86

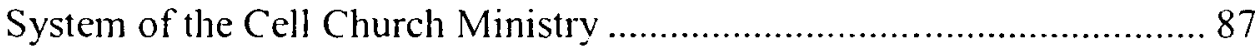

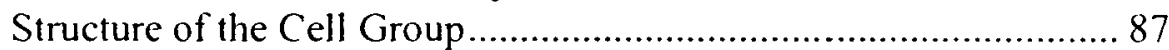

Characteristics of Cell Church Groups …………............................ 89

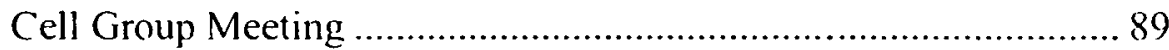

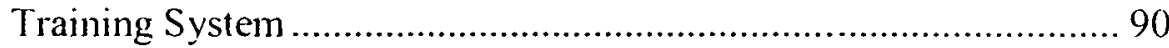

Relationship between the Church and the Cell System ................... 92

Yoido Full Gospel Church ....................................................................... 93

Background of the Church ................................................................. 93

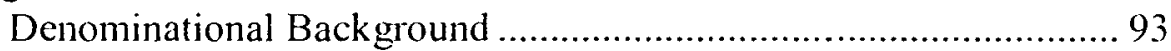

Brief History of the Church Growth ................................................. 94

Cell Strategy of Yoido Full Gospel Church...................................... 95

System of the Cell Church Ministry ..................................................... 96

Structure of the Cell Group........................................................... 96

Characteristics of Cell Church Groups ............................................ 97

The Cell Group Meeting .............................................................. 98

Training System ..................................................................... 100

Relationship between Church and Cell System .................................... 101

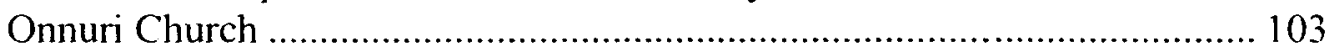

Background of the Church ............................................................... 103

Denominational Background ..................................................... 103

Brief History of the Church Growth ............................................ 104

Cell Strategy of the Onnuri Church ............................................... 105

System of the Cell Church Ministry ................................................. 106

Structure of the Cell Church ...................................................... 106

Characteristic of Cell Church Groups........................................... 107

The Cell Group Meeting ............................................................ 108

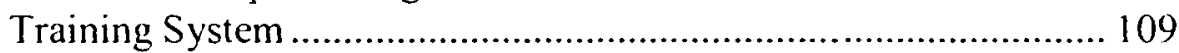

Relationship of Church and Cell System ............................................. 113

Common Characteristics of the Three Churches .................................. 115

Relationship between Church and Conference ............................. 115

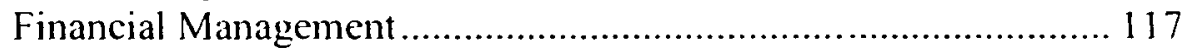

Personnel Management ........................................................... 119

Ministering Period of the Pastors............................................... 120

Remuneration of Senior Pastors............................................... 121

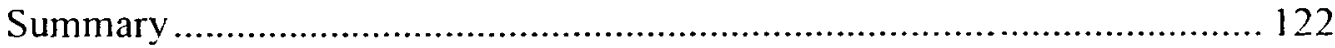


VII. DISTINCTIVE CHARACTERISTICS OF THE SEVENTH-DAY ADVENTIST CHURCH COMPARED TO THE THREE MODEL CELL CHURCHES.

Brief Background of the Seventh-day Adventist Church in South Korea.... 124

Historical Background ................................................................... 124

Growth of the Seventh-day Adventist Church ...................................... 126

Cell Strategy of the KUC .................................................................. 128

System of the Cell Church Ministry .......................................................... 129

Description of the Present Small Group Ministry....................................... 130

Relationship between Church and Cell Group System.............................. 1.32

Relationship between Local Church and Conference................................. 134

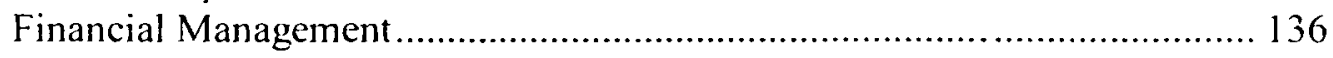

Personnel Management .......................................................................... 139

Service Period of the Pastors .................................................................. 140

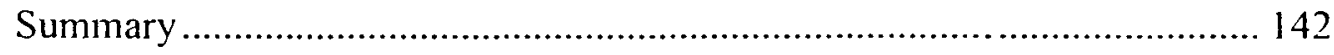

VII. SUMMARY, CONCLUSIONS, AND RECOMMENDATIONS .................. 144

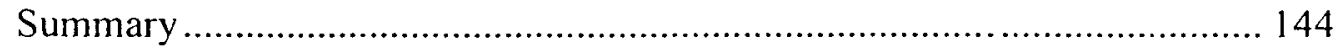

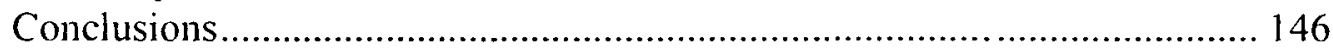

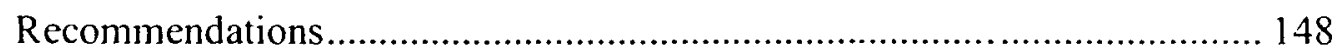

To the Local Church Pastors................................................................ 148

To the Local Conference Leaders .......................................................... 149

To the Union Conference Leaders ........................................................ 149

Recommendation for Further Studies ................................................ 150

Appendix

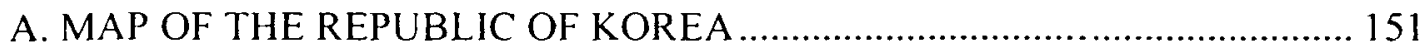

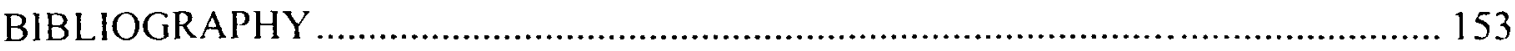

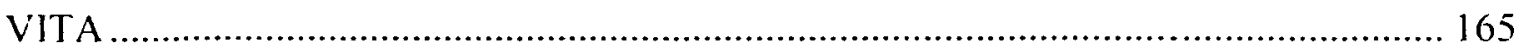




\section{LIST OF ILLUSTRATIONS}

1. Christian Population in Korea, 1974-1980 .................. 81

2. Data of the Cell Groups of the Global Mission Church, 1995-2007 ....... 85

3. Departmental System of Cell Group Ministry in GMC $\ldots \ldots \ldots \ldots \ldots .92$

4. The Departmental System with the Cell Group Ministry of the OC....... 114

5. Departmental System of KUC $\ldots \ldots \ldots \ldots \ldots \ldots \ldots \ldots \ldots \ldots \ldots$

\section{LIST OF TABLES}

1. Giftedness among Cell Leaders $\ldots \ldots \ldots \ldots \ldots \ldots \ldots \ldots \ldots \ldots \ldots, 15$

2. Finnell's Administrative Flow Chart $\ldots \ldots \ldots \ldots \ldots \ldots \ldots \ldots \ldots, 18$

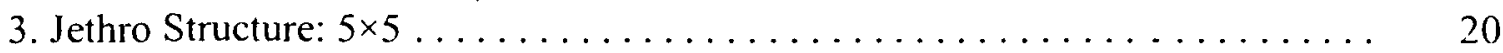

4. Comparison of Regular Cell Group with Closed G-12 Group .......... 21

5. Neighbour ${ }^{`} \mathrm{~S}$ Four $\mathrm{W}^{\star}$ s for Meeting Practice. .................. 26

6. Cell Group Organization of GMC $\ldots \ldots \ldots \ldots \ldots \ldots \ldots \ldots \ldots \ldots, 88$

7. Procedure for GMC Cell Group Meetings. ................... 90

8. Cell Group Structure of YFGC $\ldots \ldots \ldots \ldots \ldots \ldots \ldots \ldots \ldots \ldots \ldots \ldots \ldots \ldots \ldots$

9. Procedure of Cell Group Meeting of YFGC $\ldots \ldots \ldots \ldots \ldots \ldots \ldots$

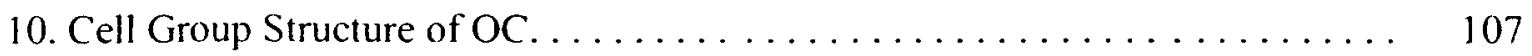

11. Procedure of Cell Group Meeting of OC $\ldots \ldots \ldots \ldots \ldots \ldots \ldots \ldots, 108$ 
12. Training Course of Cell Group Leaders of $\mathrm{O} \bar{C} \ldots \ldots \ldots \ldots \ldots \ldots \ldots \ldots$

13. Training Course of Men`s Cell Group Leaders of Onnuri Church ....... 112

14. Number of Baptisms and Pastors, $1989-2008 \ldots \ldots \ldots \ldots \ldots \ldots \ldots \ldots \ldots \ldots$

15. Church Members and Ministry Years of SDA and Cell Churches $\ldots \ldots \ldots \quad 128$

16. Type of Cell Group Practiced .......................... 129

17. Training System of Cell Group Leaders $\ldots \ldots \ldots \ldots \ldots \ldots \ldots \ldots \ldots .130$

18. Data of Small Group of KSDA, 2005-2009 ................ 131

19. Position of Cell Group Ministry in the Churches $\ldots \ldots \ldots \ldots \ldots \ldots \ldots .133$

20. Executive Characteristics of SDA and the Three Cell Churches $\ldots \ldots \ldots \ldots 135$

21. Portion of Tithe for Each Level of the SDA Church Organization ........ 137

22. Membership Fee for Conference $\ldots \ldots \ldots \ldots \ldots \ldots \ldots \ldots \ldots \ldots \ldots \ldots \ldots \ldots$

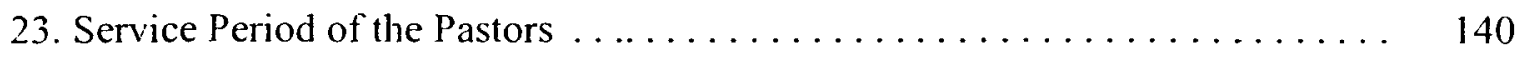

24. Length of Service of the Pastor and Membership Numbers ........... 142 


\section{LIST OF ABBREVIATIONS}

\begin{tabular}{|c|c|}
\hline $\mathrm{CCG}$ & Christian Center of Guayaquil \\
\hline ECKC & East Central Korean Conference \\
\hline $\mathrm{GC}$ & General Conference of Seventh-day Adventists \\
\hline GMC & Global Mission Church \\
\hline $\mathrm{ICM}$ & International Charismatic Mission \\
\hline $\mathrm{KCAG}$ & Korean Christian Assemblies of God \\
\hline $\mathrm{KJV}$ & King James Version \\
\hline KSDA & Korean Seventh-day Adventist \\
\hline KUC & Korean Union Conference \\
\hline NAPD & Northern Asia Pacific Division \\
\hline NIV & New International Version \\
\hline $\mathrm{OC}$ & Onnuri Church \\
\hline RSV & Revised Standard Version \\
\hline SDA & Seventh-day Adventist \\
\hline WCKC & West Central Korean Conference \\
\hline YFGC & Yoido Full Gospel Church \\
\hline
\end{tabular}




\section{ACKNOWLEDGMENTS}

This dissertation is dedicated to Jesus, my Lord, because He guided me to finally finish this dissertation. I really appreciate my family for their patience: I could not spend time with my family during these last many years because of my writing.

I cannot fail to mention my appreciation to the Korean Union Conference for allowing me to study the DMin course. I would especially like to express my thanks to the following persons: to Dr. Jeannette Bryson, for helping to correct my English. from the very beginning until now: to my dissertation advisor, Dr. Donald James. for his good teaching of cell ministry in class and allowing me to finish my dissertation: and to Dr. James North, for his careful reading and helping me to write according to the foundations of the Seventh-day Adventist Church. I want to thank Our Heavenly Father for allowing me to stay in His arms and allowing me to work for His holy ministry in Korea. May only His name be glorified throughout my life. 


\section{CHAPTER 1}

\section{INTRODUCTION}

\section{Statement of the Problem}

According to information published in a Korean newspaper, the number of Christians in South Korea has declined by 1.6 percent during the last decade.' This decline has been going on for over 20 years in the Seventh-day Adventist (SDA) churches. ${ }^{2}$ The Korean Union Conference (KUC) and local conferences have attempted to introduce various strategies for increasing the membership in the local churches. One of the most recent attempts is the introduction of cell church ministry. It has proven to be successful in some churches, such as the Global Mission Church (GMC), the Yoido Full Gospel Church (YFGC), and the Onnuri Church (OC). These churches have developed model cell churches and have experienced rapid growth. During a five-year period. the SDA Church also attempted to develop model cell churches; unfortunately, the cell church approach did not succeed. Research is needed to determine the factors that have contributed to this failure.

\footnotetext{
'Joins News Paper. "Statistical Data of Korean Religion." http: cafe.joins.com adams 436683 (accessed September 13. 2007).

'According to the data that is kept in the General Affairs Department of KUC. the number of baptisms has been holding steady at around 6.000 people annually. i.e.. at the same level for the nearly 20 years since 1990 .
} 


\section{Purpose of the Dissertation}

The purpose of this dissertation is to identify the characteristics of the Korean Seventh-day Adventist (KSDA) Church system and compare them to that of the three Korean non-Adventist churches with successful cell systems. The intent of the research is to explore the factors thought to be contributing to the success of the cell churches outside the Adventist Church system and suggest ways in which the Adventist Church system could benefit from adopting them. On the basis of the findings, action could be taken to shift from traditional Adventist Church practices to the cell church model w'ith great success.

\section{Justification for the Dissertation}

Cell church ministry is a very popular strategy among mega churches worldwide. The biggest cell church in the world is the YFGC located in South Korea. This comparative study includes the YFGC, the GMC, and the OC. Comparing the characteristics of these churches and their cell ministries with the SDA Church will give critical insight needed to develop successful strategies for a paradigm for cell ministries in the Adventist Church system.

\section{Delimitations of the Dissertation}

This research is limited to the study of the YFGC, the GMC. and the OC as compared to the SDA Church in South Korea in regards to the use of cell church ministry as an evangelistic tool. Therefore. the study is limited to finding the key factors that characterize these churches and determine how to improve the approach within the Adventist system. 


\section{Methodology}

To clarify the concept of cell church ministry, I examined current literature about cell church ministry and reviewed various dimensions of modern cell church ministry. In addition, for a better understanding of cell church ministry, I also researched its foundation in the Bible and the writings of Ellen G. White.

For practical study, the three above-identified churches in South Korea with model cell church ministries are investigated by reading related books and exploring their web sites. Personal interviews were carried out with the persons in charge of the various departments. The information and results are compared to help clarify the changes needed to help cell ministries experience success in the SDA churches.

\section{Outline of the Project}

Chapter 1 presents the general introduction, statement of the problem, purpose, justification, limitations, methodology, and expectation of the dissertation.

Chapter 2 provides a general understanding about cell church ministry from the review of related literature. It identifies the reality and dimensions of cell ministries.

Chapter 3 reviews the biblical and theological foundation of cell church ministry. The meaning of the church. identification of the characteristics of small groups, and the background of cell church ministry in the New Testament are examined.

Chapter 4 introduces Ellen G. White's concept of the (equivalent of) cell church ministry as presented in her writings.

Chapter 5 describes the general background of Korean history. including the various religions and the concept of God. 
Chapter 6 explores and identifies the characteristics of the systems of the three model cell churches in South Korea: the GMC, the YFGC, and the OC.

Chapter 7 presents the distinctive characteristics of the SDA Church and compares them to those of the three model cell churches.

Chapter 8 includes the summary, conclusion, and recommendations. It also suggests further research needed to find a strategy for the SDA churches in South Korea. Recommendations are made to the leaders of the Union Conference and the local conferences and steps are suggested that could ignite a new paradigm for the cell church ministry.

\section{Expectations of the Dissertation}

The following expectations are revealed through this dissertation.

1. Identification of the factors contributing to the success of the cell ministries in the three model cell church systems studied.

2. A better understanding of the factors contributing to the failure of the cell ministries attempted by the SDA Church in South Korea.

3. Identification of hindrances which may provide an understanding of how to introduce the cell church system into Adventist churches in South Korea.

4. Insights suggesting to the pastors ways in which they may overcome the weak characteristics of the Korean Adventist church system.

5. Inspiration for a shift to a paradigm conducive to cell church ministries.

6. Personal wisdom for me to understand better the church system that is fit for cell church ministry. 


\section{CHAPTER 2}

\section{REVIEW OF RELATED LITERATURE}

This chapter examines literature on the concept and practice of cell church ministry. It identifies the qualities that characterize the elements that make up a cell church. Research found in the publications of Ralph W. Neighbour and Joel Comiskey will be used, along with other related books and materials.

\section{Understanding General Small Groups}

For a better understanding of cell church ministry. it is important to understand the small group system, because cell groups maintain the qualities that characterize small groups. Therefore, this section defines general small groups.

Historically, there is evidence that "man has always lived in groups." ${ }^{.1}$ Small groups as communities are a very important element in the life of a human being. Animals also exhibit social behaviors with small groups, but "while sociality is a characteristic of many (but not all) animals, community is the defining characteristic of humans alone. Only humans form social groups. or webs that can exchange and share attitudes, ideas, beliefs. and identity. ${ }^{-2}$ Human beings are characterized as mammals that

'C. Gratton Kemp. Small Groups and Self-Renerial (Columbus. OH: Seabury. 1972). 1.

"Karen Christensen and David Levinson. "What is Community." Encyclopedia of Community from the rillage to the Virtual Horld (2003). 1:xxx vii. 
depend on a certain small group or community to sustain their lives.

"Social scientists have observed that there are two universal human organizations - the family and the community. ${ }^{* 3}$ As regards the relationship of the two group systems, "Some people imagine that community came after family, beginning when humans started living in bands. ${ }^{-4}$

The American Heritage Dictionary describes a group as a collection of persons or things considered as one or acting as one. ${ }^{5}$ Stewart L. Tubbs depicts a group as "a collection of individuals who influence one another, derive some satisfaction from maintaining membership in the group, interact for some purpose, assume some specialized roles, are dependent on one another, and communicate face-to face. ${ }^{-6}$ The definition points out an interaction as a core element of a group.

"Throughout most of history, the small group (three or more people) has been the unit of social life $\mathrm{e}^{-7}$ in the world of human beings. People have a fundamental need to belong to a community or small group. ${ }^{8}$

"Carl L. Bankston III. "Communities." Encyclopedia of Fumily Life (1999). 1:286.

${ }^{4}$ Christensen and Levinson. 1:xxxvii.

'The American Heritage Dictionany of the English Language (1976). s.x. "group." quoted in Arthur D. Jensen and Joseph C. Chilberg. Small Group Communication (Belmont. CA: Wadsworth. 1991). 6.

"Stewart L. Tubbs. A Systems Approach to Small Group Interaction in Christian Perspectives on Sociologl (Grand Rapids. MI: Zonden an. 1982). 152. quoted in Del Birkey. The House Church (Scottsdale. PA: Herald. 1988). 63.

Jensen and Chilberg. 5.

${ }^{8}$ Christensen and Lerinson. 1:xxxviii. 


\section{Defining Cell Church Ministry}

As a small group. "the cell group is not just a portion of church life, to include along with a dozen other organizations. It is church life. ${ }^{.9}$ Society and the church both require a division into cells to fill the needs of society in this modern time of electronic information sharing.

Comiskey defines the cell in the book Cell Church Solutions: "The most common definition of a cell is this: a group of three to fifteen people who meet weekly outside the church building for the purpose of evangelism, community, and discipleship with the goal of multiplication..$^{-10}$ Evangelism may be defined as outreach beyond a group and community refers to the relationships within a given group, but the key word regarding the concept of the cell group is discipleship. One major difference between a cell church and a generic small group is the process of discipling that takes place in a successful cell church. Leadership, then, becomes important within the cell church group. "'

Regarding the goal of enhancing growth, an explanation of the meaning of the term cell as it is used in biology is relevant. A cell in biology is "the smallest structural unit of an organism that is capable of independent functioning " in the body of living creatures. $^{12}$ It is the smallest living unit to reproduce. As the cell unit functions to

"Ralph W. Neighbour. Where Do He Go From Here? (Houston. TX: Touch. 2000). 131.

"Joel Comiskey. Cell Church Solutions: Transforming the Church in North America (Moreno Valley. C.A: CCS. 2005). 20.

"Ibid.

"The American Heritage Dictionary of the English Language (1992). s.x. "cell." 
multiply, a church cell group functions for multiplication: "cells are open. evangelismfocused small groups that are entwined into the life of the church. They meet weekly to build up each other as members of the Body of Christ, and to spread the gospel to those who don $t$ know Jesus. The ultimate goal of each cell is to multiply itself as the group grows. ${ }^{-13}$ To multiply a cell group, leadership must come from within the group. Comiskey says that "in a small group, new leaders are raised up and trained to lead a cell even as new members join. When the group is large enough, multiplication occurs. ${ }^{.14}$ As "groups usually have specific reasons for their existence. ${ }^{.15}$ a church cell group also has a specific reason to exist. It is evangelism. David L. Finnell points out that "a cell church has a 'go" structure. The church is organized to go out to meet and reach non-Christians where they live" with the purpose of evangelizing them. ${ }^{16}$

\section{Distinctive Characteristics of Cell Group Ministry}

"The basic building block of the Christian community is the small group described in Acts. Today. these small groups have been rediscovered in the cell church. ${ }^{-17}$ Small group interaction helps participants to view each other as part of the family of God. Cell church ministry is characterized as follows.

${ }^{13}$ Joel Comiskey. Hone Cell Group Explosion (Houston. TX: Touch. 1998). 17.

${ }^{1+}$ Ibid.. 21.

${ }^{15}$ Jensen and Chilberg. 9.

${ }^{10}$ David L. Finnell. Life in His Bod. (Houston. TX: Touch. 1995). 17.

${ }^{17}$ Finnell. 38. 


\section{Locations}

The homes of cell members are perhaps the best suited for the evangelistic activities prescribed for effective cell ministry. Yonggi Cho, Pastor of the YFGC in Korea, adopted home-based evangelism and established the largest membership in the world. Rev. Cho points out that "our church, however, carries out evangelism primarily through the home cell group system. Each cell group becomes a nucleus of revival in its neighborhood. ${ }^{\cdot 18}$

The location of the space within the home is critical. Cell group ministry cannot be thought of without a home strategy. The home strategy is considered a core element of the cell church system.

"The gradual but universal homecoming of the church is one of the most significant social, as well as religious, movements of our time. ${ }^{-19}$ The social aspect is considered more successful if more homes are involved. In fact, some support the theory that there should be a series of homes selected rather than just one location. Cell church members usually have home meetings “which typically move from one residence to another on a weekly basis. ${ }^{-210}$

Contrary to traditional church goals. cell churches are not limited by the size of the crowd in the room. "-By providing a comfortable atmosphere where Christianity is lived out and where non-Christians feel at ease, homes can be great tools for bringing 1981). 58.

"Paul Yonggi Cho. Successfil Home Cell Groups (Seoul. Korea: Church Growth International.

\footnotetext{
"Robert Banks and Julia Banks. The Church Comes Home (Peabody. MA: Hendrickson. 1998). 2.

2"Neighbour. Where Do Wh Go From Here" 38.

"IFinnell. 21.
} 
people to Christ. ${ }^{.22}$ The home environment creates an oikos relationship that is a critical tool for evangelism. Usually the oikos is characterized by "the persons we talk to, relate to and share with, for at least a total of one hour each week" ${ }^{\cdot 23}$ and "the average number of people in one's oikos is $8-10 .^{.24}$ In today's society, the cell church ministry functions more effectively when taking into consideration the importance of establishing home cells where oikos relationships can thrive.

\section{Multiplication of Cell Groups}

Multiplication is a critical aim of cell church ministry. It is a reason why the cell church ministry exists. Neighbour describes it as follows: “The building block of all living organisms is a cell. Anyway, cells don t grow; they multiply into more cells. Thus, the growth is composed of tiny 'mini-churches $\cdot .25$

As a living biological cell, a church group continually extends its size and divides into more cells as it multiplies. "Cell groups usually come to a time when they must multiply to remain viable. Six or seven people can become 14 or 15 in a short time. When that happens. it is mandatory for the cell to become two communities. ${ }^{.26}$

In the most resistant cultures, a time cycle of multiplication of a cell group could

"Deena Davis. Discipleship Journal's 101 Best Small-Group Ideas (Colorado Springs. CO: Navpress Publishing Group. 1996). 102.

"Cell Leader Intern Guidebook (Houston. TX: Touch. 1995). 81. This book is developed from "The Shepherd's Training Manual" by Ralph W'. Neighbour Jr.. "Cell Leader"s Guidebonk" by Ong Swee Geok. and "The Home Group” by Gatfield Christian Church.

${ }^{24}$ Finnell. 77.

"Nejghbour. Where Do He Go From Here? 107.

"lbid.. 87 . 
happen in less than a year; sometimes it could be possible within six months. ${ }^{27}$ Comiskey reports, "My research of the five Latin America countries shows that a cell multiplies in exactly six months. But that time swells to an average of nearly nine months when the Singapore and Korea statistics are included. because those churches multiply cells closer to 18 months. ${ }^{\cdot 28}$ "Dion Robert now has 80,000 cell members in Abidjan, Ivory Coast, Africa. He multiplies his cells every four to five months. ${ }^{-29}$

Larry Stockstill introduces a story of three fold multiplication of a church in three years. In Nairobi. Kenya, Pastor Donald Matheny applied cell group strategy to his church: "within three years, his church moved to an outdoor stadium with 3,500 attending each Sunday. ${ }^{-30}$

Comiskey introduced a multiplication of the Christian Center of Guayaquil (CCG). He said that "CCG is an exciting model in Guayaquil, Ecuador, that is multiplying cell groups rapidly. From 1992 to 1996, CCG grew from 16 cells to 1,600 , averaging 396 new groups per year. ${ }^{-31}$ The cell group strategy has proven to be an effective instrument by the multiplication for evangelism.

\section{Discipleship}

One of the major differences between a cell church and a traditional church is the discipleship component. Small groups may exist for a variety of reasons, some short-term

\footnotetext{
¿Neighbour. Where Do We Go From Here? ir.

"Comiskey. Home Cell Group Explosion. 102.

${ }^{29}$ Cell Leader Intern Guidebook. 97.

"Larry Stockstill. The Cell Church (Grand Rapids. MI: Zondervan. 1998). 32.

"Comiskey. Home Cell Group Explosion. 117
} 
and some long-term. but a cell church group, though a small group, has distinctive features. The main difference is the process of discipling. Discipleship is the life of cell church ministry; without that function, a cell group cannot continue. The process of evangelism and discipleship take place simultaneously through the activities in cell group ministry. Discipleship training is a process of practical ministry in a field: it is not like teaching in a classroom-a model followed by most traditional church practices. The discipling process in a cell group continues until a newcomer successfully leads another person into the group. The process of leading a new believer from conversion to baptism to making disciples comes from a committed devotion to Christ. ${ }^{32}$

Neighbour suggests that the progression includes the following steps.

1. The Shepherd leads while the Intern observes.

2. The Shepherd explains what to do and why.

3. The Intern leads while the Shepherd observes.

4. The Shepherd identifies strengths and weaknesses.

5. The Shepherd assigns tasks to overcome weaknesses.

6. The Intern leads while the Shepherd encourages.

7. The Shepherd and Intern maintain a relationship as equals in ministry. ${ }^{33}$

Comiskey presents the same idea for developing disciples: "The mother cell leader has been preparing the potential cell leader by following the model of Jesus": In

\footnotetext{
"Adapled from Neighbour. Where Do We Go From Here? 239. See a similar definition by Robert E. Coleman. The Master Plan of Erange'lism (Grand Rapids. MI: Spire. 1994). 6-10.

${ }^{33}$ Ralph W'. Neighbour. The Shepherd's Guidehook (Houston. TX: Touch Publ ication. 1996). 36.
} 
the first "I do-you watch," in the next "I do-you assist," in the third "You do-I assist" and in the last "You do--I watch. ${ }^{.34}$

Even though there are some intentional training courses, most of the training comes from working together. A cell church discipline system consists of lay ministries. The training is done by members of the group. ${ }^{35}$

Neighbour introduces the three levels for training procedures that take place from the time someone is a new church member until that person is a mature member in church.

Neighbour's materials teach cell groups to distinguish $T_{y p e} A$ unbelievers who are fairly open to the Christian faith from Type B unbelievers who "are not searching for Jesus Christ, and show no interest in Bible study or other Christian activities. ${ }^{.36}$

In the first level, children who are described as new believers dealing with significant problems need to be nurtured by the ministry of the mature members in the cell group. In the next level, young men participate in spiritual warfare and in caring for Type A unbelievers through the visitation team of the cell group. In the final level, there are fathers ${ }^{\circ}$ groups who have matured in a Shepherd Group. The fathers are involved in reaching out to Type B unbelievers as Share Group members. ${ }^{37}$

Neighbour represents it as the taxonomy of the spiritual development procedure for discipleship of cell church members. The processing consists of a logical and intentional discipleship training program systematically given according to The Year of

${ }^{34}$ Joel Comiskey. From 12 to 3: How to Apply G-12 Principles in Your Church (Houston. TX: Touch. 2003). 119.

\footnotetext{
${ }^{35}$ Neighbour. Where Do We' Go From Here? 40.

${ }^{36}$ Comiskey. Home Cell Group Explosion. 88.

"Neighbour. The Shepherds Guidebook. 38.
} 
Equipping track service. ${ }^{38}$ The discipleship process is the life of the cell church. It is the ingredient necessary to enable the cell members to produce another generation of cell groups.

\section{Leadership System}

It is true that "every human community-familial or tribal, political or religiousmust be organized around some authority which serves as a guide for corporate life. ${ }^{-39}$

Cell church ministry also organizes leadership authority, but in groups. "The authority structure of the cell church may be quite different from that in a particular denomination ${ }^{-40}$ or other organizational groups. Comiskey stated, "My commitment to cell ministry is really a commitment of leadership development. Cells are simply the best vehicle for developing leaders - they re leader breeders. ${ }^{-41}$

The first element of the leadership of all cell churches is a selection of leaders from among ordinary people. There are no specific lists of qualities required of individual leaders. Comiskey confirms it in his research as follows: "The survey of 700 cell leaders in eight countries revealed absolutely no connection between the cell leader's spiritual giftedness and success in cell multiplication. ${ }^{-42}$ Table 1 shows the result of a survey

\footnotetext{
${ }^{34}$ Neighbour. The Shepherd s Guidebook. 64. The Year of Equipping track service represents training course to develop intem to be leader by the taxonomy program.

"Bill J. Leonard. The Nature of the Church. Layman's Library of Christian Doctrine (Nashrille. TN: Broadman. 1986). 38.

"Michael Green. ed.. Church Without Walls (W'aynesboro. GA: Paternoster. 2002). 12.

${ }^{41}$ Comiskey. Cell Church Solutions. 125.

HComiskey. Home Cell Group Explosion. 29.
} 
Table 1. Giftedness among Cell Leaders ${ }^{43}$

\begin{tabular}{ll}
\hline \multicolumn{1}{c}{ Gift } & Percent Listed \\
\hline Teaching & 25.1 percent \\
Leadership & 20.3 \\
Evangelism & 19.0 \\
Pastoral care & 10.6 \\
Mercy & 10.6 \\
Other & 14.4 \\
\hline
\end{tabular}

taken to identify the gifts of the leaders in a specific organization of cell groups.

The results indicate that the gifts are varied. and the gift of leadership is present within the membership of a group. statistically representing a normal curve. This would mean that, in most groups. there will be some with the specific gift of leadership. but all the gifts are components of leadership and everyone has the potential to be a successful leader. The key factor in predicting the success of a cell church is, then, the selection process. $^{+4}$

The second element of cell church leadership is characterized by servant leadership. "The cell leader"s life is an example to other cell members how to be actively involved in the lives of people. ${ }^{.45}$ To meet the need of the cell group activities, "a servant 's heart is a necessary ingredient to effective cell ministry. Therefore, cell church leadership style is that of a servant leader (John 13). ${ }^{.46}$

\footnotetext{
"Comiskey. Home Cell Group Explosion. 29.

${ }^{44}$ Joel Comiskey. Le'adership Explosion (Houston. TX: Touch. 2000). 16.

${ }^{45}$ Larry Kreider. House to House (Houston. TX: Touch. 1995). 133.

"HFinnell. 20.
} 
The third element is a promotion of leadership. The leadership in a cell church must be promoted among the members who have been participating in the context of the cell church ministry.

Comiskey tells the story of Carl Everett who "is known as 'Mr. Multiplication" at Bethany World Prayer Center. ${ }^{-47}$ Carl multiplied his cell group and "repeated this process six times before Bethany`s top leadership, recognizing Carl`s leadership, elevated him to shepherd cell leaders. ${ }^{-4 \times}$

Comiskey speaks of how to elevate leadership among cell church ministry. The experience, according to him, prepares those with pastoral degrees to reach a deeper understanding of ministry and inspires many of the participants to go into ministry as district pastors and zone leaders as a profession. ${ }^{-19}$ To be a leader in cell church ministry: "calling and personal qualities are essential, but the ultimate test is past success as a cell leader, cell supervisor. etc. For the most part, seminary training is not a major factor in elevation to top leadership. ${ }^{-50}$ The thought is that leaders "who have risen from within intimately understand and will operate with the vision and philosophy of the company, or in our case, the church. ${ }^{-51}$

The fourth element of leadership in actual cell church ministry is represented by an intentional training course. Neighbour emphasizes the value of the intentional training

\footnotetext{
${ }^{47}$ Comiskey. Home Coll Group Explosion. 31.

${ }^{48}$ Ibid.

${ }^{49}$ Ibid.. 119.

"Comiskey. From 12103.65.

${ }^{53}$ Ibid.
} 
course for cell leaders as the Cell Leadership Equipping Track. This prepares members for progressive levels of ministry, from leading a cell group to serving as a district pastor supervising twenty-five hundred members in cell groups. In the intentional course, leadership training involves a step-by-step process.

The fifth element is the process of coaching and modeling. The intensive leadership training provides a basis for understanding the leadership role, but observing others as they take leadership roles re-enforces the learning. Then. to have a coach makes the learning curve easier. "Coaches are people who have successfully multiplied their own cell groups. ${ }^{-52}$ This person can nudge and hint and guide without taking over. Just having an experienced person with the new leader gives more confidence. As the new leader becomes the authority figure for a new cell group, a coach can still be consulted, as opposed to the traditional training where the trainees leave the classroom and are on their own.

Finnell suggests a line of leadership of cell church ministry in the book, Life in His Body, as illustrated in Table 2 below, which shows a flow chart that illustrates the "administrative flow from Christ. through the cell church, to the unsaved people in the community. ${ }^{.53}$ The table shows the system of leadership of cell church ministry. Most of the cell churches have a similar leadership system.

\footnotetext{
SComiskey, From 12 10 3, 75.

${ }^{53}$ Finnell. 141-142.
} 
Table 2. Finnell's Administrative Flow Chart

\section{Unchurched People in the Community}

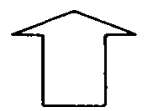

Cell Members

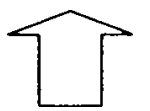

Apprentice

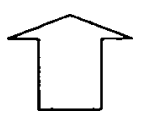

Cell servant

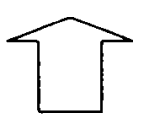

Zone Servant ( 1 per 5 Cells)

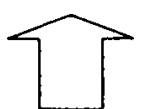

Zone Pastor ( 1 per 5 Zone Servants)

Senior Pastor

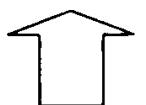

Congregation (Church)

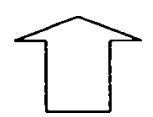

Jesus Christ 


\section{Basic Models of Cell Group Structure}

Cell church ministry has several structural styles recommended by various leaders. The list includes the following: geographical. homogeneous according to the style of cell group, Jethro or $5 \times 5$, G-12, and G-12.3 according to the organizational styles. The geographically-organized cell group is a district of cell groups arranged according to where the members are living. It is "the standard in the cell church world." .54 Another cell style is a homogeneous group. "The word homogeneous means similar in nature. Homogeneous cell groups are comprised of people with common characteristics. The most common types of homogeneous groups include the following: $^{55}$

1. Leaders who believe leadership is a process and is learned by doing

2. Family cell groups

3. Young married couples' cell groups

4. Men's cell groups

5. Women's cell groups

6. Singles cell groups

7. Adolescent cell groups

8. University cell groups

9. High school cell groups

10. Children's cell groups

${ }^{54}$ Comiskey, From 12 10 3. 124.

${ }^{55}$ Ibid.. 125. 
According to one type of organized cell structure model, there is what is called the Jethro model known as $5 \times 5$ structure. The YFGC uses this model; the leadership is organized with district pastor, zone pastor. section leader, and section supervisor. ${ }^{56}$

Neighbour and many other pastors followed Rev. Cho's pattern of cell church building. The pattern is called the Five-br-Five structure model as seen in Table $3 .^{57}$

\section{Table 3. Jethro Structure: $5 \times 5$}

Senior / District Pastor over five zone pastors ( 1.250 cell members $)$

Zone Pastor over five zone supervisors ( 250 cell members)

Zone Supervisor over five cell leaders ( 50 cell members)

Cell Leaders over ten cell members ( 10 cell members)

Another style, the G-12 structure model, started by Pastor Cesar Castellanos and known as the International Charismatic Mission (ICM), started in Bogota, Colombia. In 2007 , it had " 20,000 cell groups and 45,000 in Sunday attendance, and is known as the cell church most aggressive in developing leaders. ${ }^{.-58}$ In fact, the G-12 model began in biblical history. "The number twelve has great significance in the Word of God. Jacob had twelve sons and there were twelve tribes of Israel. Jesus chose twelve disciples.... The number twelve is linked with the elective purposes of God. ${ }^{-59}$

\footnotetext{
${ }^{56}$ Comiskey. Leadership Explosion. 173.

${ }^{57}$ Comiskey. From 12 to 3.9 .

${ }^{5 x}$ Karen Hurston. Breakthrough Cell Groups (Houston. TX: Touch. 2001). 41.

s"Comiskey. From 12 10 3.45.
} 
The G-12 cell church system has also become a powerful source for the cell group ministry models worldwide. ${ }^{60}$ The number "twelve is generally agreed to be the upper limit ${ }^{* 61}$ for cell church ministry groups.

Table 4 shows how Comiskey presents a major difference between a G-12 and a regular cell group.

Table 4. Comparison of Regular Cell Group with Closed G-12 Group

\begin{tabular}{ll}
\hline Regular Cell Group (Non-Discipling) & Closed G-12 Group (Discipling) \\
\hline Meets Weekly & Meets Biweekly (at lCM it meets weekly) \\
Meets Outside the Church Building & Meets Inside the Church Building or a \\
Focuses on Evangelism & Home. \\
Anyone Can Attend & Focuses on Discipleship \\
& Only Cell Leaders Can Attend. \\
\hline
\end{tabular}

Later, Comiskey suggested a change in the G-12 cell structure to form the G12.3. In the G-12.3 structure, a full-time pastor oversees twelve cell leaders, while a lay leader cares for three daughter cell leaders and continues to lead an open group. Those models have a structure in each cell group. The three divisions include the three subgroups within a cell group. ${ }^{62}$ In cell church ministry, there are many other formats to organize the group according to the needs, function. and vision of the group.

"Comiskey. From 12 to 3.23.

"Daris. 35.

"Neighbour. The Shepherd's Guidehook. 15. 


\section{Basic Tools and Materials for Cell Group Ministry}

Cell church ministry requires many materials to facilitate the system. They consist of training books, administrative documents, management guides, and other informative publications. Most cell churches have developed their own materials. ${ }^{63}$ As the first step to getting their own materials, a new cell church could adopt materials from other churches that have been proven to work well.

Neighbour advises that the building up of materials is critical to the success of the ministry. He recommends that leaders develop a taxonomy of materials designed for equipping a Christian from conversion to productive maturity and into reproductive ministry. He emphasizes that training must be given step-by-step in a logical manner. according to the level of the learner's understanding.

Usually "the material used in most traditional churches is endless. It is often great material, but it doesn ${ }^{-1}$ lead to a specific destination. Because the focus is on general education, there's no limit to what must be learned and direction for the person being educated. ${ }^{-64}$ In contrast to the traditional church, cell churches have specific goals to reach at each step and during each period before the launching of their ministries. Therefore the materials also are limited according to the steps to reach.

According to Comiskey, "the materials in these equipping tracks promote the basic doctrines of the faith (along with the specific vision of the church), spiritual life

\footnotetext{
${ }^{6.3}$ Comiskey. Leadership Explosion. 167.

${ }^{\text {os Ibid. }}$.
} 
development, evangelism, and leadership training. They are concise and clear and don ${ }^{\circ}$ overwhelm the learner."

As cell leaders lead cell groups, they are offered additional material (even a threeyear Bible college course). ${ }^{66}$ In the case of Neighbour ${ }^{\circ}$ equipping track, there are a number of booklets including the following: Nevi Christian Development, Bible Curricula, Evangelism Training. Gifts of the Spirit. Spiritual Warfare, and more.

The ICM uses three main books written by Castellanos called Encounter I, Encounter 2, and Encounter 3. All three books are based on biblical doctrine and mixed with the vision of the church. The goals of the group are also given. After the apprenticeship training, the student begins leading a cell group and, at the same time, additional, higher-level material is made available. Another group, the Little Falls Christian Centre, has developed its own material. Each book leads to higher-level learning. ${ }^{67}$

For cell church administrational management, some materials are required. In the case of Bethany`s cell church, the church offers cell offices, a mailbox for each cell leader, tracking charts for the wall, and statistical accountability for every level of leadership. All cell leaders submit statistical reports. Every level leadership, district pastor, zone pastor, and section leader must also submit a report of his/her activities. ${ }^{68}$

\footnotetext{
${ }^{65}$ Comiskey. Leadership Explosion. 165-66.

:.0 Jbid.. 166.

${ }^{6,7}$ Ibid.

${ }^{\circ S}$ Comiskey. Home Coll Group Explosion. 116.
} 
Neighbour offers some helpful documents for use in administering a cell structure. They include the following: ${ }^{(9)}$

1. Cell group covenant

2. Report of cell group meeting

3. Journey guide interview

4. Cell group flock

5. Cell group guest list

6. Cell group attendance

7. Cell leader's self-evaluation form

8. Intern evaluation form

9. Prayer chain

10. Cell group meeting evaluation

11. Cell group planning sheet

12. Topic planning sheet (useful in planning edification times)

13. And intercessory prayer list.

There are some principles for the tools of cell church ministry. First, it has a taxonomy procedure for training cell church members to be leaders. Second, there are materials for administrative officers. cell leaders, district leaders, and the leaders throughout the system of cell church ministry. Third, there are management documents with instructions on how to direct and care for cell group members. Fourth, certificates are given as rewards for encouragement to cell members and leaders. The main concern is that a cell group needs many different kinds of materials in order to function well. The

\footnotetext{
(") Neighbour. The Shepherd's Guidebook. 237-251.
} 
materials must show the system of interaction and inter-relatedness in order for the cell church to succeed.

\section{Meeting Practice of the Cell Group Ministry}

To be a successful cell church, the group must provide a proper meeting format and place. As mentioned previously, the best meeting place is in the various homes.

The meeting must be programmed and ready for the satisfaction of every attendee in the meeting. As with any other small group meeting. "the weekly cell meetings are also structured to follow a standard four-segment agenda of welcome, worship. works and word. ${ }^{.71}$ The meeting usually begins with a warm welcome to the members of the cell group: an ice-breaker leads the introduction period. The next section of the program is worship for 30-60 minutes. After worship, the members pray together with one another. This is called the works stage. In the final section of the program, the emphasis is to focus the Word of God in a practical application in their daily lives. ${ }^{71}$

Neighbour introduces a rather different program for the meeting. "A helpful and concise way to remember the basic format and purpose of the cell meetings is with four Ws. ${ }^{-72}$ The four Ws mean welcome. worship, word, and works. See Table 5 below.

\footnotetext{
${ }^{76}$ Green. 9.

${ }^{71}$ Ibid.

"Neighbour. The Shepherd's Gurdebook. 170.
} 
Table 5. Neighbour's Four W's for Meeting Practice

\begin{tabular}{lll}
\hline Section & Activity & Flow \\
\hline WELCOME & Ice breaker & You to Me \\
WORSHIP & Singing & Us to God \\
WORD & Edification & God to Us \\
WORKS & Share the Vision & God through Us \\
\hline
\end{tabular}

In the first stage, Welcome, "a cell group must be recreated each time it meets. -Ice breakers form simple sharing questions or activities and are a great way to help people get in touch with each other and buy into the meeting. ${ }^{.73}$

In the second stage, Worship is similar to the other church programs. "The purpose of this part of the meeting is to connect us to God in worship. Besides singing. this may include prayer or Scripture reading. ${ }^{.74}$

In the third stage. the Word is the focus. This is a time for edification based on the Scriptures. "In a cell meeting you aren't trying to convey volumes of new Bible knowledge. The goal is to discover and apply the simple truths of Scripture as people in your group reflect on their own experience..$^{-75}$

In the last stage. Works, the cell meeting includes a time of "sharing the vision" with each other. "Occasionally, you will have someone share a testimony of what the group has meant to them. Often, you will use this time to pray for unsaved friends and family members. You can use this portion of your meeting to plan Cell parties for

\footnotetext{
${ }^{73}$ Neighbour. The Shepherd's Guidebook. 170.

${ }^{74}$ Ibid.. 71 .

${ }^{75}$ Ibid.. 172.
} 
reaching out and building relationships with their unbelievers. ${ }^{-76}$

Finnell suggests that a typical cell group meeting lasts for about ninety minutes and that the maximum time should be two hours. ${ }^{77}$ The meeting program consists of six stages as follows:

1. Ice Breaker (10-15 minutes)

2. Praise (10-15 minutes)

3. The Word (10 minutes)

4. Edification (30-40 minutes)

5. Evangelism (15-20 minutes)

6. Fellowship ( 10 minutes). ${ }^{78}$

Mike Neumann introduces another outline for cell group meetings in The Deeper Christian Life Ministry in Accra. The meeting lasts ninety minutes, beginning at 5:30 p.m. and ending at 7:00 p.m. ${ }^{79}$

Comiskey says. "I believe that a one hour or one and a half hour meeting is sufficient. ${ }^{-80}$ The content of a cell meeting consists of prayer and worship. the lesson, quality control (worship. sharing prayer requests, prayer, and vision casting are vital aspect of the meeting), and friendship. ${ }^{81}$

${ }^{70}$ Neighbour. The Shepherd's Guidebook. 176.

Finnell. 87.

${ }^{78}$ Ibid.. 92.

"Mike Neumann. Home Groups for Lrban Cultures (Pasadena. CA: William Carey Center. 1993). 63.

"Comiskey. From 12 10 3. 133.

"Ibid.. 133-135. 
Most of the meetings conducted through cell church ministry. generally, consist of ninety minutes to two hours.

The aim of the meeting is to build relationships, not just to conduct a meeting by following an agenda. The cell leader guides the cell members step-by-step through each stage successfully, leaving the members looking forward to the next meeting.

\section{The Strengths and Weaknesses of the Cell Church System}

The Strengths of the Cell Church System

Cell church ministry is an excellent system to mobilize the members of a group to reach outside the church and to evangelize the world in modern society. In fact, the system brings many strengths to the cell church members.

Michael Green points out some of the advantages of cell church ministry: The cell church underlines the essential nature of church as the people of God instead of the church building as a church in the traditional church`s view. ${ }^{82}$ Also, cell churches have a system where every believer ministers to serve God and people. The "cell is by far the most attractive context into which to invite enquirers. The warmth, the laughter, the food, the involvement of one and all, the readiness to pray for one another and the determination to live out what they learn-all this is winsome. ${ }^{.43}$ One of the most important advantages of cell church groups is their ability to multiply. ${ }^{8-t}$

\footnotetext{
"Green. 128.

\$. Ibid.. 129

"Ibid.
} 
Neighbour counts seven reasons why cell group ministry is more appropriate for world-class cities than the traditional church. ${ }^{85}$

1. They are more efficient than traditional churches.

2. They are based on the scriptural concept of community.

3. They focus on the importance of prayer for their ministries.

4. They penetrate deeply into the structures of the city, reaching people in a more personal way than the traditional church will ever be able to do.

5. It is a movement with structures that are truly flexible, able to adapt to their environment.

6. They are not circumscribed by the size of a church building.

7. Their evangelism includes the powerful witness of Christ working within His body, beyond the traditional, cognitive presentation of the plan of salvation.

"The distinctive strengths of the cell church include dynamic evangelism, an effective system of pastoral care, equipped lay people, sound community life, and a mobilized church, which results in dynamic church growth and is well poised for missions. There is also much room for further innovative development of the cell church system for different circumstances and for changing times. ${ }^{-.86}$

According to this research, the cell church system contains more power to strengthen and to give advantages than any other system the church has ever had before.

\footnotetext{
"Neighbour. Where Do He Go From Here? 28-30.

stGreen. 12.
} 
The Weaknesses of the Cell Church System

Although cell church ministry has many positive aspects, there are some perceived weaknesses. Those most frequently mentioned include the following pressures.

1. Time: the slow nature of group processes and arbitrary deadlines.

2. Social: pressure to conform, groupthink tendencies, social loafing, and reserve productivity.

3. Ego: fear of being dependent, individual domination. status apprehension, competitive climate, and egocentric communication.

These weaknesses can be addressed, but as Green points out, "It requires a wholehearted acceptance by the pastor, the lay leaders and the members of the church if they are to move in this direction. That is not easy to achieve. ${ }^{.87}$

Another concern is the image perceived by the neighbors. Some will think that the group is a cult or represents an odd belief system. People usually think of a church as a large group of people meeting in a particular style of building. ${ }^{88}$ "A more serious danger concerns the leadership of cells. . . Not every ordained minister is a gifted trainer, and if he is not, there is serious danger of poorly trained leaders being put in charge of a dozen or so members of the congregation. ${ }^{.89}$

The possible weak areas affiliated with the pastor in the local area might be minimized by regular sessions between the pastor and the cell group leaders. but it remains a genuine danger. and every effort must be made to give cell leaders continuous

\footnotetext{
${ }^{87}$ Green. 125.

${ }^{s s}$ Ibid.. 126.

s'lbid.
} 
and careful training. to avoid burnout and to maintain harmony. ${ }^{90} \mathrm{Cell}$ church groups must overcome these problems in the ministry. The failure of the cell church planters was caused by these same problems. To be a successful cell church ministry, a cell group must overcome these kinds of weaknesses and disadvantages in the cell ministry.

${ }^{\prime \prime}$ Green. 126. 


\section{CHAPTER 3}

\section{BIBLICAL FOUNDATION OF A CELL CHURCH}

\section{Small Groups in Biblical Perspective}

This chapter examines the biblical foundation of the cell church. The study focuses on the meaning of the following terms: church, small group, and cell church. It includes a brief description of the background of the Early Church and the biblical foundation for cell church ministry. This chapter provides strong support for cell group ministry as one of God's intentional plans for the world mission in the twenty-first century.

\section{Possible Prototype Cell Group Community at Creation}

To understand what might be the first cell group. one needs to understand the Trinity of the Godhead, because the Trinity of the Godhead is one of the core doctrines that supports and represents the substance of a small group community. The relationship between the three members of the Godhead appears to function like a household of human beings. They interact deeply with each other and mentor each other like that expected of a small group community. The concept of community must be a part of the character of God, and a part of the nature of God is a dependence on community.

The relationship between the three members of the Godhead appears to function like a household of human beings. They interact deeply with each other and mentor each other like that expected of a small group community. The concept of community must be 
a part of the character of God, and a part of the nature of God is a dependence on community.' Thus. the small group concept was found in the Trinity of God before time began. It might be described as a prototype of cell group community.

There are many evidences to represent God`s existence as a plural formation. When God created heaven and earth, God declared "Let us make man in our image. after our likeness" (Gen 1:26 RSV). In the text, He used the plural terms "us" and "our" to point to Himself, because the Godhead consists of the Father, Son, and Holy Spirit.

Garth Weldon Icenogle expresses his support of this truth in the following statement:

It may be overly dramatic to say that God lives as a small group, but the church has historically described God as Trinity, three persons in one. . . God is described as existing in divine community, in dialogue with other members of the God-self, an intracommunicating group who also created humanity to exist in group intracommunication. $^{2}$

Another one of the characteristics of God is the multiplication of numbers. The Bible reveals that God desired to multiply His community by creating human beings in His image. "God said, 'Let us make man in our image, after our likeness"” (Gen 1:26).

Icenogle explains that the first small group community was a reflection of God's character. The human community is created as male and female, a reflection of the image and likeness of God. Male and female together is intrinsic to the address of and receptivity to God. In order to reflect this full community of God rightly, both men and women must be together in human community. ${ }^{3}$

'Finnell. 35.

'Garth Weldon Icenogle. Biblical Foundations for Small Group Minisrn (Downers Grove. IL: InterVarsity. 1994). 21.

?3enogle. 22. 
The family unit was a full reflection of God's image of a small group in community beginning with Adam and Eve (Gen 1 :26-27). The creation of man and animal included male and female. not a single entity, but two. Interestingly, "plurals are basic to all that God creates. ${ }^{-4}$ Multiplication of the original groups is also according to God's plan. This is seen in His directions to Adam and Eve. According to God's original plan. the first family began to enlarge their community by having Cain and Abel (Gen 4: 12). Even after the entrance of sin. the first family continued to multiply, and their family members spread out all over the world, producing children according to the command of God given after creation (Gen 5:1-6:2).

Not only did God have a cell group, but He enlarged the group by His own participation. Eventually, the original group included man, woman, and Godhead. "The small group is the base community in which men and women can be with God and one another, to be, to plan, and to act for the careful nurturing of created things. ${ }^{-*}$

As the previous chapter represented, there are some core components that make up a cell group: one is the number of participants in a group. second is the ability to increase the number of group members. and third is the discipling process that takes place. According to biblical records, God and the first human family group had similar elements and practices characteristic of the modern cell group. Therefore. God and the 1991). 109 .

${ }^{4}$ Leonard Sweet. Quanum Spiritualitu: A Postmodern Apologetic (Davton. $\mathrm{OH}$ : Whaleprints.

"Donald James. "Mankind is Created for Community." in Cell Intensive I (Berrien Springs. MI: North American Division Evangelism Institute). chap. 3. page 1.

"James. chap. 3. page 23. 
first human family can be described as the first and oldest prototype in existence in the world.

\section{The Early Small Group as a Cell Group}

The Small Group Church that Jesus Initiated

A core characteristic of cell group ministry is to multiply the same system, just as a biological cell system multiplies: thus the title. cell group ministr. because cell groups multiply within the same group system. Given this fact. the Early Church is closer to cell group ministry than any general small group. The Early Church has continued to reproduce. even until now. For this reason. the Early Church small groups could be identified as the prototype of today"s small groups.

When Jesus began His public ministry, He introduced a new style of ministrysmall groups established to multiply within the same system. It appears that this was the strategy that Jesus conceived in His heart from the very beginning of His public ministry. Jesus built His small cell church strategy by steps.

Jesus changed the concept of worship from a physical location to a spiritual state (John 4:20-24). Therefore, there was no need for a specific place to meet, such as a synagogue. but individuals could meet together with God in any location. Thus there is no mention of Jesus establishing a specific building or type of building for meetings.

In the second stage, Jesus said to Peter, "I say also unto thee. that thou art Peter, and upon this rock, I will build my church" (Matt 16:18 KJV). He called and organized individuals into a living church, a small group, that consisted of human beings who believe in Jesus. Thus. church was not related to any building formation. 
In the third stage. Jesus declared that "where two or three are gathered together in my name, there am I in the midst of them" (Matt 18:20 KJV). The Word confirmed that a small group meeting could take place anywhere: on the beach, in a house, in the mountains. in a garden. even in a house. He promised to be any place where His believers gather together.

In the final stage. Jesus showed an example by the celebration of what is now known as the Ordinance of Humility and the Lord's Supper held in the upper room of a house. a private house. Other houses were also adopted during His public ministry (Matt 8:10.14:26:7.18). “The house or home figured prominently in the mission of Jesus as described in the Synoptics. Jesus often gives special teaching en oiko, at home. ${ }^{-7}$ In the first part of His ministry, "Jesus focused on the small band of disciples. His teaching, the final Passover, and His prayer in Gethsemane were all done in the presence of this small group. ${ }^{. .8}$

One of the prominent evidences is that Jesus used principles that are used in cell churches. Icenogle states that "Jesus changed human history through the process of forming an intentional small group of twelve persons.".9

Jesus focused on future leaders and expected that the small group would create disciples and be multiplied in number. "He first developled a prototype, a working model. This was His primary work during the last three and a half years of ministry." Jesus initiated His small group church by steps. 1989). 20

Vincent Branick. The House Church in the IIritings of Paul (Wilmington. DE: Michael Glazier.

"Neumann. 25. 


\section{Small Church Grouping as a Strategy for the Early Church}

"Jesus developed a strong strategic church in Jerusalem from which new church starts would be transplanted all over the world. Paul followed this strategy as he transplanted churches from his home base in Antioch. ${ }^{\cdot 10}$ The small church grouping process is what Paul used as his key strategy to spreading the gospel to the world (Rom 16:5: 1 Cor 16:19: Col 4:15; Phlm 2: etc)." According to biblical record. the members gathered in house meetings following the resurrection of Jesus. The Early Church, no longer meeting in the temple. had to find places to meet, and they began to meet in homes that would later be referred to as "house churches" set up into what is now referred to as the cell church format that was the same format as the church that Jesus planted after Pentecost. ${ }^{12}$

The pattern of cell church meetings in a house was effective and fostered the astonishing growth of the Early Church. ${ }^{13}$ The small group church became the basic unit of the church`s life throughout the first several centuries. ${ }^{14}$ The strategy of Jesus was successfully achieved. The Early Church turned the world "upside down" through cell church ministry. ${ }^{15}$

"Icenogle. 14.

"'William A. Beckham. Redefining Revial: Biblical Patterns for-Missions, Erangelism and Growth (Houston. TX: Touch. 2000). 187.

"Branick. 18.

'Beckham. 72.

${ }^{13}$ Ibid.. 26.

${ }^{14}$ Birkey. 65.

${ }^{15}$ Birkev. 120. 


\section{Essential Elements of the Small Group Church in the Early Times}

The small group church of the first century kept the essential elements that the modern cell church system requires. The system was quite a different system from the traditional temple system. These groupings must have been somewhat individualisticdependent on the leader to determine the direction. They must have had the essentials required for growth as seen in the rapid spread of Christianity. "Today, churches desiring to be New Testament cell churches must go through the same prototype stage. ${ }^{.16}$ These important facts are discussed in this section.

\section{Oikos/Family of God}

The very important concept of oikos in the cell church groups is found in the biblical writings. It is rooted deeply in the family relationship of the church in the house meetings. The term appears throughout the whole New Testament record (Acts 16:25-34: Eph 5:19). The Greek word oikos is translated as house. family, or household.

David Finnell describes oikos as a network of relationships with people of common kinship. interest. goals, problems, age, and etc. The oikos is made up of five spheres of relationships: relatives. neighbors, shared interests. common needs, and common tasks. $^{17}$

Therefore, the term oikos implies that the Early Church was made up of small units such as that found in a family with household roles and relationships. "The family

\footnotetext{
I'Beckham. 16.5.

${ }^{17}$ Finnell. 75.
} 
unit was the first and most important small group ordained by God." 18 Therefore, Jesus established the oikos strategy in His ministry. He said. "For whosoever shall do the will of my Father which is in heaven, the same is my brother, and sister, and mother" (Matt 12:50 KJV). When Jesus spoke to Mary Magdalene after His resurrection, He addressed His disciples as brothers. with the following words, "Go to my brethren, and say unto them. I ascend unto my Father, and your Father. and to my God, and your God“" (John 20:17 KJV).

In the Lord's prayer, He referred to God as His father: "Our Father which art in heaven“" (Matt 6:9 KJV). Jesus transitioned the way humans referenced God. seeing God at a distance, denoting the relationship with human beings. His disciples also used the relational title when addressing fellow believers. They preferred the title brother to any other titles. Paul, Peter, and John called believers “brethren“ when writing letters (Rom 1:13:1 Cor 1:1; Gal 1:1: Phil 1:12;1 Thess $1: 4 ;$ Heb $3: 1 ; 2$ Pet $1: 10 ; 1$ John $3: 13$ ). James, the brother of Jesus, also used the title brethren (Act 15:13; Jas 1:2). The oikos as true community is found only in the Kingdom of God. ${ }^{19}$

In the Bible. the number twelve is a familial number. When twelve persons gather, they can function together as if they are family. When twelve gather. they can reach out to others and include them into their extended family. Twelve was a continuing symbol of God's adoption of Jacob's twelve sons. Thus, Jesus continued that historical familial 1998). 15.

"David Cox. Think Small Groups (Alma Park. Grantham. Lincs. England: The Stanborough Press.

\footnotetext{
"Neighbour. Where Do He Go From Here?" 103.
} 
paradigm in calling twelve to gather with him. ${ }^{20}$

Paul mentions that "you are no longer foreigners and aliens, but fellow citizens with God's people and members of God's household (oikos)" (Eph 2:19 NIV). The term oikos reveals the real character of the small church groupings and is used abundantly in the New Testament. The relationship was a critical element of the small church groupings in the New Testament and encompasses the extended family of the Kingdom of God.

\section{Home Base}

Joel Comiskey states. "I love cell church planting because you do not have to start with buildings and bucks. You start with people and a simple New Testament format that fully utilizes the home. ${ }^{-21}$

This house strategy was formed by Jesus. He sent His disciples from house-tohouse to proclaim the Gospel message with these words, "Peace be to your house" (Luke 10:1-7 [v. 5]). He ministered in many houses, eating with publicans and sinners (Matt $9: 10)$. He raised a girl from death $(9: 25)$, healed many patients $(9: 28-30)$, presented and taught (13:36). For example. He sat at the table in the house of Simon the leper (26:6) and shared the Last Supper with His disciples in a large upper room (Luke 22:12). Jesus appeared to His disciples in a house two times after His resurrection (John 20:19, 26). From the time the Early Church used homes and houses for their meeting places, most activities occurred in a believer's home. Acts 2:41-47 tells of the believers in Jerusalem who were together and broke bread in their homes daily. In Ephesus. Troas.

\footnotetext{
2 Icenogle. 129.

"Comiskey. From 12 to 3.143.
} 
Rome. and wherever the Christian movement spread, small churches in houses came into existence. Paul"s letters refer to these groups as the "church that meets in their [Priscilla"s and Aquila"s] house" (Rom 16:5: 1 Cor 16:19) or "Nympha and the church in her house" (Col 4:15 NIV) or "the church that meets in your [Philemon"s] home " (Phlm 2 NIV).2.

The "Synoptic portrayals. closely linking the missions of both Jesus and the disciples with homes. may in fact reflect historical memories about Jesus and the first disciples..-23

Home meeting places made possible the sharing of meals and loving hearts and interaction with each other. In most of the house meetings. participants ate meals together in the tradition of the Lord's Supper. They sang. They taught each other by giving opportunity for each to offer a hymn, a lesson, a revelation, a tongue, or an interpretation (1 Cor 14:26). The meeting in the home provided dramatically strong relationships among the church members. ${ }^{24}$

The strategy of evangelism, being centered in home meetings, opened a special door to the people who might not otherwise participate in worship. Male Jews usually attended the temple worship only three times each year. Women, however. were not allowed to participate at the temple worship, nor were Gentiles. These customs were obstacles to the spreading of the Good News to the whole world. Adopting the home strategy, the first early church overcame the problem and began to grow rapidly and penetrate the homes and. thus, family units. Women, Gentiles, and anyone else who

\footnotetext{
"Lois Barrett. Building the' House Church (Scottdale. PA: Herald. 1986). 20.

23 Branick. 20.

${ }^{24}$ Barrett. 20-21.
} 
wanted to join in the worship of God could worship together without any barrier if the gathering took place in a home.

The following summary of the cell church group meetings in the home points out these positive aspects. First. Jesus gave a model and showed examples of activities in houses. Second, a home was a very economical method of providing a shelter for meeting without extra money. Third, it was a positive environment to represent the reality of the Kingdom of God as one family. Fourth, it was an excellent place to participate without any obstacle due to position or levels of authority existing outside the home. And fifth, it formed a place of refuge when believers were being persecuted for their beliefs. "The early church was a home-based movement ${ }^{.25}$ as are modern cell churches.

\section{Servant Leadership}

The leadership of the Early Church was formed by Jesus Christ. He introduced quite a different leadership from that of the Israelite religious leaders or any other leaders. To the leaders of the early small group churches. leadership was not lordship, the holding and exercising of ultimate authority over the group members, but servant leadership. ${ }^{26}$ Jesus Christ as the leader of the small group of disciples was different from the rabbis or other political leaders.

Robert K. Greenleaf defines servant leadership as follow's: "Servant-leader is servant first. It begins with the natural feeling that one wants to serve. to serve first. Then

\footnotetext{
Noumann. 26.

?henogle. 79 .
} 
conscious choice brings one to aspire to lead. ${ }^{-27}$ Jesus revealed the true meaning of servant leadership. For example. when He and His disciples gathered together at the table for the Lord's Supper, He served. He washed the feet of His disciples. He announced "If I then, your Lord and Master, have washed your feet: ye also ought to wash one another s feet. For 1 have given you an example. that ye should do as I have done to you“" (John 13:14-15 KJV). In fact, the strategy of Jesus was the leadership strategy in the Early Church. Jesus intentionally gave the example to His disciples to follow His model.

The Australian cell church group leader. John Mallison. confessed that Jesus is the best of all teachers in the world. He has further described Jesus as the living lecture. ${ }^{28}$ "Jesus lived for the Twelve so that the Twelve could live for the world. He trained the Twelve so that the Twelve could lead the church into Christian discipleship and change the world forever. .29

Paul also adopted the servant model and practiced the example in his life and modeled it to his converts. He called himself a servant, even a slave. "Most translations of Romans 1:1 call Paul a 'servant of Jesus Christ'. but the Greek word 'doulos' can be translated either as servant or slave. ${ }^{-30}$

\footnotetext{
2 Robert K. Greenleaf. The Senctm as Leader (Indianapolis. IN: The Robert K. Greenleaf Center. 1991). 7 . 1989). 4.

${ }^{2}$ John Mallison. Groning Christians in Small Groups (Sydney. Australia: Scripture Union Books.

3"Icenogle. 199.

31"Reta Halteman Finger. A Simulation Paul and the Roman House Churches (Scottsdale. PA: Herald. 1993). 79.
} 
Ōther Apostles also referred to themselves as servants of God just as Paul did. The brother of Jesus described himself as "a servant of God and of the Lord Jesus Christ" (Jas 1:1 KJV), as did Jude, John, and Simon Peter.

Comiskey depicts the leadership of Jesus with this expression. Jesus "conquered with the sign of a towel. With the washing of their feet. he established the symbol for servant work. He declared, 'I have given you an example" (John 13:15). In this manner, Jesus contradicted all other models of influence and self-importance. ${ }^{.31}$ The spirit of servanthood became a foundation of leadership in the Early Church. It was the key to church growth and spreading the Good Nev's to the whole world in the New' Testament.

\section{Discipleship}

Jesus had no institution, organization or buildings in which to teach and train His disciples formally when He ministered in this world. However. His discipline was unique. Jim Egli studied the Gospel of Mark very carefully and reported that forty-nine percent of the content of the book is related to the time that Jesus spent with His disciples in His public service period. ${ }^{32}$ It means that Jesus stayed with His disciples at least half of His public service period. He worked with His disciples. planned together with them, and shared with them. He mentored by His life. character. thinking. and ministering. They did everything together and functioned as a unit, much as a strategy of modern cell church group practices. His discipline, goals, and purpose were different from those of rabbinical schools, where the leaders were trained to lead through position and power. Jesus

\footnotetext{
"3irkey. 87.

"Paul M. Zehr and Jim Egli. Allernative Hodels of Mennonite Pastoral Formation (Elkhart. IN: Institute of Mennonite Studies. 1992). 43.
} 
announced, "For I have given you an example. that ye should do as I have done for you" (John 13:15 KJV).

Jesus taught his disciples by His working model. Peter mentioned the life of Jesus: "For even hereunto were ye called: because Christ also suffered for us. leaving us an example, that ye should follow his steps“ (1 Pet 2:21 KJV).

Michael J. Wilkins defines discipleship as "living a fully human life in this world in union with Jesus Christ and His people, growing in conformity to His image. and helping others to know and become like Jesus. ${ }^{.33}$

Therefore, the relationship between Jesus and His disciples moved away from "learning" to be characterized more readily by imitation of conduct in their common living activities. ${ }^{34}$ The Apostle Paul passionately pled with his followers to accept the new paradigm: "Be imitators of me. as I am of Christ" (1 Cor 11:1 RSV). Imitation is a very significant element of discipleship. In other words, the best strategy to use to make disciples is by modeling.

Another discipleship principle that Jesus used is that of deliberate selection. It is quite an innovational procedure. Most organizations or leaders usually choose apprentices from some excellent group of persons, but Jesus chose common people from different professions for His mission.

It is surprising that Jesus did not choose key, prominent men to form part of His twelve. Jesus called Peter and his brother Andrew. fishermen: and he called James and

\footnotetext{
"Michael J. Wilkins. In His Image: Reflecting Christ in Evervday Life (Colorado Springs. CO: Nav.Press. 1997). 111.

${ }^{3-4}$ Michael J. Wilkins. Following the Master: A Biblical Theology of Discipleship) (Grand Rapids. MI: Zondervan. 1992). 78.
} 
his brother Johñ to be his disciples. He said, "Follow me, and l will make you fishers of men“ (Matt 4:19 RSV). He also invited Matthew. a tax collector. None of Christ"s disciples occupied important positions in the synagogue, nor did any of them belong to the Levitical priesthood. Rather, they were common laboring men with no professional training. no academic degrees. and no source of inherited wealth. Most were raised in the poor parts of the country. ${ }^{35}$

The selection from among the common people of His time was a powerful foundation for the early small church group movement because anybody who was faithful and had qualifications became a leader of the church. "After Jesus returned to the Father, his disciples began to duplicate this kind of ministry. ${ }^{\cdot 36}$ His disciples exercised the same ministry that Jesus exemplified before them and trained disciples in the same way. As Jesus announced to His disciples, "Teaching them to observe all things whatsoever I have commanded you“" (Matt 28:20 KJV). so they continued. Paul repeated the same word to Timothy "and the things that thou hast heard of me among many witnesses. the same commit thou to faithful men, who shall be able to teach others also“" (2 Tim 2:2 KJV).

"Jesus changed human history through the process of forming an intentional small group of twelve persons ${ }^{-37}$ and His disciples multiplied the churches continually following the model of Jesus. "Thus, it is seen again and again that the Twelve were a prototype group for the wider community of disciples. ${ }^{.38}$ These characteristics of the

\footnotetext{
${ }^{35}$ Comiskey, Leadership Explosion. 30.

3. Jeffrey Arnold. The Big Book on Small Groups (Downers Grove. IL: InterVarsity Press. 2004). 21.

"Icenogle. 199.

${ }^{38}$ Jbid.. 123.
} 
Early Church group should be a prototype model in discipleship to the cell church group in modern times.

\section{Special Strategies for Erangelism}

In the New Testament. the Early Church used special strategies to establish effective evangelism. Three of these strategies related to the structure of the church ministry system are examined in this section: equality of everyone, all believers are members of the priesthood, and women can serve as leaders.

\section{Equality of Everybody}

Equality of persons was not a part of the hierarchical systems of the Old Testament. The position of the male Israelite was dominant; women and non-Israelites were subordinate. The woman's position in society and family was debased to the level of chattel, and women were seen as a means of obtaining children. Women are repeatedly linked with children and slaves. ${ }^{39}$ Jesus changed this situation, "upheld the rights of women and moved away from a completely male-oriented position. ${ }^{-40}$ He also broke the barrier between Israelite and Gentile. The cross of Jesus demolished the distinctions of Jew and Gentile, slave and free: It settled the radical dilemma in the human world. ${ }^{41}$

In the new religious environment, they accepted the idea of equality among believers. This concept of equality that everybody is the same in Jesus was a factor that helped the church facilitate harmony among different peoples, nations, sexes, and social

\footnotetext{
"Mary J. Evans. Women in the Bihle (Downers Grove. IL: InterVarsity. 1983). 33.

${ }^{41}$ Sakae Kubo. The God of Relationships (Hagerstown. MD: Review and Herald. 1993). 82.

"1Birkev. 91.
} 
levels. It made it possible to empower all church members to be involved in evangelism ministry. The teaching of equality between male and female, Israelite and Gentile, free and slave in Christ was one of the revolutionary teachings of New Testament times.

\section{All Believers as Priests}

On the basis of the concept of equality. the teaching that everyone belongs to the royal priesthood of believers was also taught to every believer. In the New Testament. there was no barrier between clergy and laity. "The whole Church is a royal priesthood (1 Pet 2:9) only because it takes part. as a body. in the activity of Christ, its head, in the world. The Church, the body of Christ. is the sign and instrument of the unique priesthood of Christ, for the salvation of mankind. ${ }^{-42}$

"Laity is a word derived from the Greek word for "people" and it means all the people of God (1 Pet 2:9-10). It is a term of incredible honor. In Christ all the laity becomes ministering persons. ... The laity are the ministers. ${ }^{-43}$ Today people still use the term laity in contrast to clergy or professional ministers in the churches. However. the dividing level was demolished in the Early Church. The Apostle Peter declared all believers to be a part of the royal priesthood (1 Pet 1:9). Therefore no one is exempt from ministry for God. ${ }^{44}$

${ }^{42}$ Max Thurian. Priesthood and Ministry. trans. Paula Clifford (Oxford: Mowbray. 1983). 9.

"Merton B. Strommen. The Innorative Church (Minneapolis. MN: Augsburg. 1997). 142-143. quoted in David Cox. Future Church (Alma Park. Grantham. Lincs.. England: Stanborough Press. 2001). 138-139.

${ }^{44}$ Kubo, 151-152. 
The people of God are all priests. Some at present serve as full-time priests. but nevertheless, every member of the church belongs to the priesthood. It should be emphasized also that every minister is part of the Laos. the laity. In other words. the church must emphasize that all are priests and all are laity. ${ }^{45}$ The biblical record proclaims that there is not to be a special group of the church serving as its officials, but "all Christians are priests. ${ }^{.46}$ A royal priesthood directly expresses the mission of the church in the world. ${ }^{47}$

\section{Women`s Ministry}

In the time of Jesus, the role of women was restricted to domestic duties "such as cooking, washing clothes. feeding and nurturing the children. "preparing her husband's cup, and washing his face. hands and feet.' Excluded from public worship, she could participate only at home. ${ }^{-48}$ Women were allowed into "the Temple precincts only as far as the court of the women. They did not count at all for the quorum of ten necessary for a synagogue service to be held; thus women on their own could never hold an official service. ${ }^{.49}$

William P. Barker represents the women's position as follows. Primitive societies subjected women to a position verging on slavery. The women bore the children

${ }^{45}$ Kubo. 154.

t'Hans King. The Church (New York: Sheed and Ward. 1967). 371.

${ }^{47}$ R. Paul Sterens and Phil Collins. The Equipping Pastor (New York: Alban lnstitute. 1993). 105.

${ }^{45}$ Ben Witherington III. Women in the Minism of Jesus: A Sully of Jesus s Atutude to Women and Their Roles as Reflected in His Earthly Life (Cambridge: University Press. 1984). 4-8. quoted in Kubo. 80.

41)Evans. 36. 
abundantly, reared them, kept the hut in repair, gathered the food in woods and streams and fields, cooked, cleaned, made all the clothing, and carried the goods if the tribe moved. ${ }^{50}$

Women's ministries were limited to housework. Jesus, however. changed the position of women 's ministry to encompass public service. The treatment and attitude of Jesus toward women was revolutionary at that time. "Most scholars acknowledge that Jesus treatment of women represents a radical break with the Jewish cultural tradition of His time. ${ }^{.51}$ A clear and consistent portrait of Jesus emerges from the gospel traditions: His attitude toward women was startlingly new; He was able to mix freely and naturally with women of all sorts, and women followed and ministered to him. The relationship of Jesus with women was an amazing fact in that day. 52 The ministry of Jesus was the sign for the new age in which the church was to ordain women to the priesthood and open to them the door to participate in the activities of the church. ${ }^{53}$

Richard Bauckham introduces even woman's apostleship in his book Gospel Women. Now that it is generally recognized that Paul knew and had great respect for at least one woman apostle, Junia (Rom 16:7), we must certainly also conclude that he

\footnotetext{
${ }^{51}$ William P. Barker. Women and the Liberator (Old Tappan. NJ: Revell. 1972). 9.

${ }^{51}$ Samuele Bacchiocchi. Women in the Church (Berrien Springs. MI: Biblical Perspectives. 1987). 46.

$5 \mathrm{G}$. N. Stanton. Jesus of Nazareth in Nen. Testamen Preaching (London: Cambridge University. Press. 1974). 151-152.

${ }^{53}$ Bacchiocchi. 90-91.
} 
would have taken for granted that women were included in an appearance to "all the apostles. ${ }^{-54}$

Del Birkey points out "In referring to an elder (presbutero) in 1 Timothy 5:1-2, Paul also mentions female elders (presbuteras). In chapter 3:1, each trait Paul lists for elders applies to women as well as to men. ${ }^{.55}$

Women were described as leaders in the small church in the houses. "Women, with and in the presence of men, had authority in the church body. ${ }^{-56}$ and also "Women. even as men, had gifts for edifying the body.. .57

With these powerful changes of woman's status in the church. evangelism was not limited to the pastors or leaders or apostles of the church. Everybody who was baptized participated in delivering the Good New's to others. The calling of God to deliver the message was extended to the ministry of the women.

The ministry of women was possible on the basis of three events. One was the equality of everybody in Christ. Second was the priesthood of all believers for the purpose of proclaiming Christ. Last, Jesus Himself treated women equally with men in His ministry. The events powerfully influenced the believers and non-believers in society. As a revolutionary. Jesus changed women's status to be ministers to participate in the ministry of the Gospel. It was an evolutionary event at the time of Jesus. ${ }^{58}$

\footnotetext{
${ }^{54}$ Richard Bauckham. Gospel Women (Grand Rapids. MI: Eerdmans. 2002). 310.

sis. Birkey. 94.

${ }^{56}$ Ibid.. 95-96.

${ }^{57}$ Ibid.. 100 .

${ }^{5}$ Kubo. 86.
} 
Consequently. women's ministry became a powerful resource of evangelism in the churches of the New Testament period.

\section{Powerful Ceremonies of Christ}

The Early Church had two significant ceremonies that Jesus instituted before His ascension: baptism and the Lord`s Supper with its Ordinance of Humility.

\section{Baptism}

Baptism originated from the Essenes and was exercised by John the Baptist. Jesus adopted it for His ministry. "John"s baptism in water was the natural model for Christian baptism. The fact that Jesus let himself be baptized by John the Baptist represents the institution of Christian baptism, because what Jesus had done, every Christian must do. ${ }^{.59}$ The baptism of Jesus represented a very important meaning to the church.

For the early Christians, baptism marked a radical break with the past and a new openness toward the future. In the baptismal act, the faith of the individual is united with the faith of the community. It is a public declaration of the believer"s faith and desire to follow Him. ${ }^{60}$ It represents a profound concept to the person who is willing to be baptized fully by immersion in water. ${ }^{61}$

Participation in the Body of Jesus Christ by baptism is "identification with Jesus in His death and resurrection. What has happened to Him has happened to us. His death is

\footnotetext{
5"Niels Hyldahl. The History of Early. Christianit? (New York: Peter Lang. 1997). 86.

"nitLeonard. 71.

"Ibid.. 72 .
} 
our death; His resurrection is ours. ${ }^{-62}$ They now felt themselves a part of the body of Jesus Christ as a member of the church. So "baptism is the initiatory rite for membership in the world church, the community in that it is a sign of the unity of humankind. ${ }^{-63}$

There was not any difference among the believers who were baptized in the name of the Trinity. They could become one community as one Body of Christ. To baptize into the Body of Christ is to baptize into the believer's community. The baptism was not simply baptism into the church as an abstract idea, "but into a tangible flesh-and-blood expression of the church, evident in a particular community of believers. ${ }^{\text {.nt }}$

This ceremony became a significant mark of admission to the group of believers, acceptance into the family of God in the Early Church. Baptism is. therefore. not only a condition, but also a guarantee of being made a part of the church. Man is removed from the loneliness of his own ego, and finds a home in the community. On the basis of this sign, he can be sure and proud of his membership. "Baptism gives such a radically new character to man, that he can only receive it once. ${ }^{.65}$

The Early Church viewed Jesus" baptism as "the first step along the way to the cross. ${ }^{\cdot 66}$ Paul writes, "Therefore we are buried with him by baptism into death" (Rom 6:4 KJV) and "Buried with him in baptism" (Col 2:12 KJV). He related the baptism with the death of Jesus on the cross. To be baptized meant to take the first step to the cross.

\footnotetext{
"-Leonard. 71.

"Veli-Matti Karkkainen. An Introduction to Ecclesiolog! (Downers Grove. IL: InterVarsity. 2002). 220 .

${ }^{64}$ L.eonard. 128.

(5ing. 210.

"Leonard. 70 .
} 
For this reason, the church in the first century was an intentional cell church community group. People could not become members of the church by accident or without thought or commitment. Before they became church members, they had to take this decision seriously. ${ }^{67}$

Baptism indicated the beginning of the Christian's movement towards Christ and identified believers as a distinct group who would spread the message to the world. To be baptized at that time was equated with the decision to be a martyr for the Christian movement. The baptismal ceremony was a very strong covenant of devotion for God and a commitment to ministry as a part of the body of Jesus. Baptism was an act that united the church and formed a witness of the power of God.

The Lord's Supper

To the small church groups, conducting services following the pattern of the Lord's Supper was a meaningful device to keep them in the faith, in the unity of Christianity, and ready to perform their mission in the world. Before the crucifixion of Jesus, He sat down with His disciples at the table for the Last Supper in a house. ${ }^{68}$ established a New Covenant, and commanded His disciples to keep the ceremony until His return.

The ceremony of the foot washing, eating the bread, and drinking the wine has been interpreted and labeled in many different ways. "The word 'Eucharist ${ }^{\circ}$ means thanksgiving and is the name given in many churches to the meal instituted by Jesus on

\footnotetext{
Barrell. 29.

${ }^{68}$ Birkey. 65.
} 
the evening before His crucifixion. Other churchès call it 'Holy Communion', 'The Lord's Supper', 'The Breaking of Bread' or 'The Mass. ${ }^{-\cdots 9}$ The church, as a cell group, can experience several benefits by participating in the Lord"s Supper. One such benefit is the renewal of a relationship with Jesus. "The meals this "small group" shared were very special. Their life together was shattered by the crucifixion but the group again found Jesus with them in the breaking bread ${ }^{\cdot}{ }^{70}$

The Lord's Supper also points decisively to the cross.

The bread like Christ's body is "given." The cup like Christ"s blood is "poured out" (Matt 26:26-29; Luke 22:14-9). It was a serious symbol to the observers. To observe the supper is to "proclaim the Lord"s death until he comes" (1 Cor 1:26 NIV). Therefore. the Supper points to salvation secured in and through the cross. It provides a dramatic opportunity for the church to take up the cross and follow Christ. ${ }^{71}$

The meal was not a one-time-event ceremony in the church. According to the instruction that Jesus left His disciples, the churches continually carried on the ceremony of the Lord's Supper. ${ }^{72}$

The Lord's Supper was also a powerful source of the church's unity. It was a significant source of fellowship and identity in house churches. ${ }^{73}$ The Lord ${ }^{\circ}$ S Supper pointed to believers as the body of Jesus. "The meal was thus a symbol of their

\footnotetext{
${ }^{69}$ Roger Bowen. So I Send You (London: SPCK. 1996). 48.

${ }^{71}$ William J. Lunny. The Jesus Option (New' York: Paulist. 1994). 1.

${ }^{71}$ Leonard. 75.

${ }^{72}$ Barret1. 20.

${ }^{73}$ Leonard. 76.
} 
commitment to each other as well as to the death-and-resurrection of Jesus. As brothers and sisters in God's family, they saw the common meal as part of the glue that continued to bind them together. ${ }^{.74}$ Church members participated in unity as they shared a piece of bread. ${ }^{75}$ It built fellowship with Christ, with other Christians as well, and reveals the true nature of the community. ${ }^{76}$ Paul questioned that in this world "the cup of blessing which we bless, is it not communion of the blood of Christ? The bread which we break, is it not the communion of the body of Christ? For we being many are one bread. and one body: for we are all partakers of that one bread" (1Cor 10:16-17 KJV).

The Lord"s Supper helped the followers to experience the "not-yet" heavenly banquet "already here" through the presence of the Holy Spirit. ${ }^{77}$ Thus. the earliest church gathered at a home table in a shared, domestic experience in foretaste of the heavenly banquet. ${ }^{78}$

Baptism and taking part in the Lord's Supper became integral parts of the ministry of the world church. ${ }^{79}$ "The Word of God is both spoken and enacted. When the church celebrates baptism and the Lord`s Supper, it proclaims the Word of God without words.... These two symbolic events define the nature of the church in its calling to

\footnotetext{
${ }^{74}$ Barrett. 53.

${ }^{75}$ Leonard. 21.

${ }^{76} \mathrm{King} .223$.

"Bowen. 50.

${ }^{78}$ Birkey. 124.

-1) Karkkainen. 220.
} 
preach the gospel (kerugma) and make disciples (didache). ${ }^{-80}$ Together, they empowered the Early Church to remain faithful and stimulated the participants to maintain a connection with God and to reach out and invite others to participate.

\section{Summary}

In the study of the Bible is found the strong supporting foundation of the cell church ministry as a biblical strategy. It is rooted in biblical theology and even in God Himself. The study of the biblical background of the small group church ministry revealed a deep relationship and similar principles and practices between the early church groups. In the first century, there were no seminaries or schools of theology, yet the Gospel message spread from house to house. The small group that Jesus established and trained, only twelve disciples, turned the whole world upside down. In Acts, it is reported that a powerful movement of evangelism was going from Jerusalem to the whole world. Small church groups with their home-based ministry were powerful witnesses to the power of Jesus` life and ministry. According to this study, small church group ministry is an effective strategy for evangelism and its practice is rooted in a biblical foundation.

\footnotetext{
${ }^{80}$ Leonard. 70.
} 


\section{CHAPTER 4}

\section{UNDERSTANDING OF CELL CHURCH MINISTRY \\ FROM THE WRITINGS OF ELLEN G. WHITE}

Ellen G. White s writings include teaching and advice regarding small group ministries, much like the current cell church system. This chapter traces the history of small groups as referred to in the writings of White, and her suggestions that could relate to cell church ministry.

\section{Small Group Ministry and Ellen G. White}

White experienced small group activities herself and participated in the movement of Adventism through small group meetings.

\section{Early Influence of Home-Based Meetings}

White was born into a Methodist family.' "Her parents, Robert and Eunice Harmon, were residents of Maine. They were earnest and devoted members of the Methodist Episcopal Church."-2 Thus, she was accustomed to attending church meetings with her parents in her childhood. Even though they had converted to Adventism, they

'Ellen G. White. Life Sketches of James White and Ellen G. White (Battle Creek. MI: Seventh-day: Adventist Publishing Association. 1880). 172.

${ }^{2}$ Ellen G. White. "Parentage and Early Life." Signs of the Times. 6 January 1876. Ellen G. White Writings Complete Published. 2007 ed.. CD-ROM (Ellen G. White Estate. 2007). 
attended Methodist classes. White wrote, "My father's family still occasionally attended the Methodist church, and also the class meetings held in a private house. One evening, my brother Robert and myself went to class meeting." ${ }^{.3}$ Another record tells that "Not long after this, we again attended the class meeting. ${ }^{.4}$ In the meeting. she gave a testimony about the love God and the belief in Christ's coming. But the class leader interrupted her speaking. About the meeting, she wrote, "Thus my testimony closed. the last that I was to bear in class with my Methodist brethren." and "We were conviced that we ought no longer to attend the class meeting. ${ }^{\cdot 6}$ After becoming more involved with the Adventists, her father acted as a leader of the Adventist meetings in private homes. ${ }^{7}$ The practice of holding small group meetings in private houses continued, and consequently, the home-based meeting style influenced White's religious life.

\section{Small Group Ministry}

After the great disappointment, early Adventists naturally met together in their homes with those who had had the same experience. ${ }^{8}$ These Adventists had no church buildings or organized groups. Thus, they frequently gathered together for prayer and Bible study as a small company in their homes. In this environment, the movement of

\footnotetext{
${ }^{3}$ Ellen G. White. Christian Experience and Teachings of Ellen G. White (Mountain View. CA: Pacific Press. 1922). 35.

${ }^{4}$ Ellen G. White. Life Skerches of Ellen G. White (Mountain View. CA: Pacific Press. 1915). 45. Ellen G. White Writings Complete Published Edition 2007, CD-ROM (Ellen G. White Estate. 2007).

${ }^{5}$ White. Christian Experience and Teachings of Ellen G. White. 37.

"Ibid.. 38.

'Ibid.. 39.

${ }^{8}$ Godfrey T. Anderson. Outriders of the Apocalypse (Mountain View. CA: Pacific Press. 1972). 26.
} 
Adventism continued with most followers meeting in small groups in homes.

White describes such a meeting as follows: "Most of our meetings were held in private houses. Our congregations were small,,${ }^{\circ 9}$ and also, "Brother Colcord, who left for Melbourne sooner than we did, spoke twice to this small company. Brother Corliss also spoke once or twice; then, W.C.W. and myself spoke on Sabbath and Sunday to those who attended the meetings. ${ }^{-10}$ The history of a little company assembled to worship on the Sabbath day is also found in her writings." Sometimes. the meetings were held in the kitchen of a home, as the following records, "Years ago, when the company of believers in the soon coming of Christ was very small, the Sabbath-keepers at Topsham, Maine, met for worship in the large kitchen in the home of Brother Stockbridge Howland. ${ }^{.12}$ The pioneers who experienced the great disappointment naturally adopted small group and private meetings for their activity strategy to overcome the situation. They experienced, as the early church did in the first century, the small group-style meetings. As the small groups gathered together in private rooms, kitchens, barns, and other places for their meetings, worship, evangelism, prayer meetings, and other purposes, White used these venues to further her ministry.

\footnotetext{
"Ellen G. White. Testimonies for the Church. 9 vols. (Mountain View. CA: Pacific Press. 1948). 1:75.

"Ellen G. White. Manuscript Relecrses. 21 vols. (Silver Spring. MD: Ellen G. White Estate. 1990). 19:269.

"Ellen G. White. The Ellen G. White 1888 Materials (Washington. DC: Ellen G. White Estate.
} 1987). 735 .

'Ellen G. White. Counsels for the Church (Nampa. ID: Pacific Press, 1991). 290. 


\section{A Strategy of Small Group Ministry}

In the writings of White there is much said about the need to develop a strategy for small group ministry, now better known as cell church group ministry, rather than under the broader category of small groups that could refer to any meeting regarding any topic with any goal.

\section{Concept of Small Group Ministry}

White held the conviction that the development of a small group ministry that would mentor and disciple, a group that would share and multiply, would work for both the churched and the unchurched. One piece of support for the belief that White supported cell church ministries is found in the Australasian Union Conference Record, issued on August 15, 1902: "The formation of small companies as a basis of Christian effort is a plan that has been presented before me by One who cannot err. If there is a large number in the church, let the members be formed into small companies, to work not only for the church members but for unbelievers. ${ }^{-13}$ She emphasized the concept that cell church group ministry is a necessary means for believers and unbelivers as an evangelistic tool.

The early SDA Church leaders paid attention to her advice, because it came with a strong emphasis on the origin, " the One who cannot err." She advised. "If in one place there are only two or three who know the truth, let them form themselves into a band of workers. ${ }^{-14}$ White went on to recommend that the leaders of the churches organize small

\footnotetext{
${ }^{13}$ Ellen G. White. Evangelism (Washington. DC: Review and Herald. 1970). 116.

${ }^{14}$ White. Testimonies for the Church. 7:21
} 
units or working groups in every church, much as is done in the cell church ministry today.

\section{Training Strategy}

White suggested that every church have a training center to work with the members, showing them how to conduct meetings, how to act their parts in missionary labor, and how to reach people successfully. She pointed out that the church must offer an actual program to help all church members to exercise the ministry of God in church and outreach. She is quoted as saying, "Many would be willing to work if they were taught how to begin. They need to be instructed and encouraged. Every church should be a training school for Christian workers. ${ }^{-15}$ In her instruction, the concrete concept and strategy of how to train church members is revealed. For the most powerful training. White recommended studying the life of Christ and following His footsteps in training learners and preparing lessons. She stressed that modeling as an educational strategy, patterned after the example Jesus left when He was in the world, is the key to successful ministry. $^{16}$

She suggested that training that involves experienced workers interacting with new learners works best. ${ }^{17}$ According to her, inexperienced young men and women should be trained under the direction of experienced, consecrated leaders and learn how

${ }^{15}$ Ellen G. White. Coumsels on Diet and Foods (Washington. DC: Review' and Herald, 1976). 470.

"Ellen G. White. "A Risen Saviour." The General Conference Bulletin. 24 May 1909. 14-15.

${ }^{17}$ Ellen G. White. Instruction for Effective Christian Senice (Hagerstown. MD: Review and Herald. 1947). 32. 
to labor successfully. ${ }^{18}$ She praised the training model with these words, "One example is worth more than many precepts. ${ }^{-19}$ This is the same strategy Jesus used to select and train His disciples. It is still the key to discipling people today and can be accomplished by introducing them to cell church ministry practices.

\section{Home-Based Evangelism}

White mentioned that "every Christian family is a church in itself." ${ }^{.10}$ It seems that to her thinking, the family is a very important unit and must function as a part of the ministry of the church. She stressed that public meetings cannot reach everyone. The last message of mercy to the world must be presented to fathers, mothers, and children in regard to home religion..$^{21}$ Thus, it seems that she envisioned building a home missionary system, starting with small groups in private homes, and then reaching out to those in the area.

She told us to seek to follow more closely the example of Christ, the Great Shepherd, and suggested as a model how Jesus passed through villages and came in personal contact with the people in their homes, teaching and ministering to their necessities. ${ }^{22}$ "Christians who are living in the great centers of commerce and travel have

${ }^{18}$ White. Elangelism. 108.

${ }^{19}$ Ellen G. White. The Ministr of Healing (Mountain View. CA: Pacific Press. 1942). 149. Ellen G. White Writings: Comprehensive Research. 2008 ed.. CD-ROM (Ellen G. White Estate. 2008).

"Ellen G. White. Notebook Leaflets from the Elmshaven Librany (Payson. AZ: Leaves-of-Autumn Books. 1985). 77.

"Ellen G. White, Child Guidance (Washington. DC: Review and Herald. 1954). 556.

"Ellen G. White. Loma Linda Messages (Elmshaven. Sanitarium. CA. 1906). 180. Ellen G. White Writings Complete Published. 2007 ed.. CD-ROM (Ellen G. White Estate. 2007). 
special opportunities. Believers in these cities can work for God in the neighborhood of their homes. ${ }^{.23}$

White stressed the usefulness of the home-based meeting as follows: "The presentation of Christ in the family, by the fireside, and in small gatherings in private houses, is often more successful in winning souls to Jesus than are sermons delivered in the open air, to the moving throng, or even in halls or churches. ${ }^{.24}$ Therefore, she suggested that families learn simple songs, ${ }^{25}$ and by humble, heartfelt prayers and by a simple presentation of Bible truth in the family circle evangelize their own children. ${ }^{26}$ In her mind, ministry must first focus on the home. It is the same strategy that cell church ministry exercises in today's modern period.

\section{Mobilization of All Church Members}

White understood that every member of the church, and even the new converts, should participate in the ministry of the church. Everyone who is added to the ranks by conversion is to be assigned a post of duty. The biblical passage, Matt 28:19-20, constituted the great charter of the early church: "Go ye therefore, and teach all nations, baptizing them in the name of the Father, and of the son, and of the Holy Ghost." In the word. "You," Christ included all believers to the end time of the world. It is the duty of the ministers to train the enlisted men and women to do work for God. These men and

\footnotetext{
23Ellen G. White. Gospel Workers (Washing1on. DC: Review and Herald. 1948). 352.

${ }^{24}$ Ibid.

${ }^{2}$ Ellen G. White. Welfure Ministry (Washington. DC: Review and Herald. 1952). 93.

2"Ibid.. 70.
} 
women need to be taught to labor in missionary lines. "Every church-member who has been truly converted is to be given some work. ${ }^{.27}$ These instructions are powerful recommendations for pastors to get involved in cell church group ministries, but not just pastors. White suggested that every church member has a duty to hold small group meetings with their neighbors:

Let the believers living near the place where you are holding meetings share the burden of the work. They should feel it a duty and a privilege to help to make the meetings a success. God is pleased by efforts to set them at work. He desires every church member to labor as His helping hand, seeking by loving ministry to win souls to Christ. $^{28}$

According to White, there is no exception in the ministry of God in the church but everybody must participate in the responsibility for the churched and the unchurched.

\section{Meeting Practices}

White encouraged every church to have small group meetings. The meetings must include certain contents. According to her, there must be a set time of prayer and a time set aside for presenting messages regarding the Truth of the Word of God, shared simply and clearly. She also talked about taking time to welcome each person and providing a time to draw near to each other and together to God. Songs of praise can be sung. She

${ }^{27}$ Ellen G. White. “Second Reading." Supplement to Review and Herald. 21 June 1898. Ellen G. White Writings Complete Published. 2007 ed.. CD-ROM (Ellen G. White Estate. 2007).

${ }^{2 *}$ White. Manuscript Releases. 4:275. 
supported the idea that a private house could provide a positive place for such meetings. ${ }^{29}$

She also encouraged members to share their active involvement in ministry and suggested that there should be special ministry meetings where reports could be given. The exchange of experiences, particularly successful outreach ventures, should be full of interest and life. Jesus received reports of the activities that His disciples performed in the field. On this basis, White encouraged every member who participated in ministry to report his/her activities and experiences every week before the other church members. ${ }^{30}$ The sharing of these successes encourages others in the group and helps identify the needs of the group. These kinds of meeting practices are similar to those of the time of cell church meetings.

She also advised church members to pray for blessings in practical situations. One example is that of a particular Los Angeles church: "The blessing of the Lord will come to the church members who thus participate in the work, gathering in small groups daily to pray for its success. Thus the believers will obtain grace for themselves, and the work of the Lord will be advanced. ${ }^{-31}$ The record points out the important role of prayer to success. In the meeting, she again suggests singing, sharing, Bible study, praying, and reporting.

?"Ellen G. White. An Appeal for Self-Supporting Laborer (Nashville. TN: Associated Leciurers" Bureau. 1933). 10.

\footnotetext{
"White. Gospel Workers. 199.

${ }^{31}$ White. Erangelism. 111.
} 


\section{Role of the Pastor for Small Groups}

White said that the ordained pastor who does not train the members to work in various departments of the church does not exercise a shepherd's care over the flock of God. In this case. the church members will expect to be tended like sick children. ${ }^{32}$

For her. the pastor must be the trainer and organizer for the church. His major role, in her opinion, was to organize the members into small groups and to prepare them to work for God in soul-winning efforts. ${ }^{33}$

She introduces an impressive scene happening in one of her dreams. An owner of a large mill fired his superintendent, who worked hard to make some simple repairs in a wheel-pit while several workers in the line were standing by, idly looking on. The reason for his lay-off was given: "I employed you to keep six men at work. I found the six idle, and you doing the work of but one. Your work could have been done just as well by any one of the six. I cannot afford to pay the wages of seven for you to teach the six how to be idle. ${ }^{.34}$ The dream carried a warning to the leaders of the church to train all church members to work in cooperation with the pastor. The following two passages explain how the pastor works as a trainer and points out the role of pastors:

The minister should at first seek not so much to convert unbelievers. as to train the church-members for acceptable co-operation. Let him labor for them individually, endeavoring to arouse them to seek for a deeper experience themselves, and to work for others. When they are prepared to sustain the minister by their prayers and labors, greater success will attend his efforts. ${ }^{35}$

\footnotetext{
"White. Testimonies for the Church. 6:434.

$\therefore$ White. Gospel Workers. 197.

$\because 1$ lbid.

35 lbid.. 196.
} 
Wherever a church is raised up, the minister should not consider his duty done until it is thoroughly organized and placed in working order. Every member should become a missionary. All should be given something to do to help spread the light of truth, for this very activity will cause them to grow in spirituality. ${ }^{36}$

White even intimates that any pastor who is performing ministry instead of training his members for ministry should be fired. ${ }^{37}$ She stressed the importance of developing the people who have talent in the church for the Master's use. A wellorganized plan for the employment of workers is needed to instruct the members how to labor for the upbuilding of the church and also for unbelievers. The practical plan included the following: (1) how to work, (2) how to conduct meetings, (3) how to act their part in missionary labor, and (4) how to reach people successfully. ${ }^{38}$

In summary, White's idea concerning the need for a pastor, who is called to serve, to recognize that the calling is not only to preach, teach, visit, encourage, comfort, and evangelize - all important parts of pastoral work - but to organize and train the members. disciple them. In the cell church ministry system today, the role of pastors is still the same: organizing and training (discipling) members.

\section{Cell Church Ministry}

White was convinced that a church divided into small groups would experience a renovating. reforming, energizing power. ${ }^{39}$ Therefore, she urged the leaders of every church to establish training sessions to instruct church members and to train through

\footnotetext{
3"Ellen G. White, "Laborers Together with God." Review and Herald. 24 August 1886. 529.

"White. Instruction for Effective Christian Service. 197-198.

${ }^{38}$ White. Testimonies for the Church. 5:257.

"White. Welfure Ministry. 107.
} 
example ministry and modeling opportunities in practical activities with experienced instructors. ${ }^{40}$

\section{Summary}

To summarize the viewpoint of White concerning small group ministry, the following list identifies the components: (1) the church has a plan for training members; (2) experienced and inexperienced persons work together; (3) every member has a role in the church; (4) each individual, youth and adult, is encouraged to develop according to his/her abilities; (5) home is considered an essential training ground for evangelism; (6) prayer is the accepted key to success in the ministry: (7) the pastor must work to organize church members to work in harmony; and (8) the ministry group should be organized as a small group. The strategy for small group ministries suggested by White is very similar to that of the cell group ministry system.

White said, "Too much time is devoted to the churches in preaching. This is not attended with the best results. The work of the Lord's ambassadors is to organize a company of workers to hunt for the souls who need help; but hours are spent in preaching that had better be devoted to personal, house-to house labor. ${ }^{.+1}$ She must be considered a visionary leader of the cell group church ministry as illustrated in her writings.

A'White. The Minism of Healing. 149.

"EJlen G. White. "To Every Man His Work." Australasian Lnion Conference Record. 25 February 1907. 1. 


\section{CHAPTER 5}

\section{CONTEXTUAL BACKGROUND OF KOREA}

This chapter presents a brief description of South Korea. It reveals the background of the religious tendency that is reflected from historical components such as the geography, people, history, traits. and religions of South Korea.

\section{General Synopsis}

The official name of South Korea is the Republic of Korea and the capital city is Seoul. Ethnically, Korean peoples came from one ancestor, Ural Altai, a member of a Siberian tribe. The country uses only one language, Korean, and has its own writing system, HanGeul, which was invented by King Sejong. 'HanGeul is composed of 14 consonants and 10 vowels. In one year, 2007, Korea exported $\$ 371,466$ million (U.S.) and imported $\$ 356,845$ million (U.S.). According to the 2008 statistical report published by The International Trade Association of Korea, the country ranks eleventh in trade among the exporting countries of the world. ${ }^{2}$

The Korean Peninsula and all of its associated islands are located between latitudes $124 \mathrm{E}$ and $131 \mathrm{E}$ and longitudes $33 \mathrm{~N}$ and $43 \mathrm{~N}$. Geographically. Korea is neighbor

'Geon C. Park. Cartoon Korean Historn (Hurst. TX: J \& S, 1999). 162.

'Oh My New's International. "Korea. Last Year's Export Ranked $11^{\text {th }}$ in the World . . 1 Step Up," hup: english.ohmynews.com articleview article_view.asp".no $=3525778$ rel_no $=1$ (accessed May 30 . 2008). 
to three big countries: Russia, located to the north; China, directly to the west; and Japan, across the East Sea. The land of Korea covers an area of about 85,563 square miles, and is divided between the Republic of Korea (South Korea) and the Peoples Republic of Korea (North Korea). ${ }^{3}$ (See appendix for map.)

According to demographic reports of July 2002, the population of Korea was 47.6 million, an increase of 1.5 times in comparison to the population of 32.2 million in 1970 . The population density in 2002 was 479 people per square kilometer, the third most densely populated country in the world, after Bangladesh and Taiwan, excepting the citystates. $^{4}$

\section{History of Korea}

Korean history reaches back more than 4,000 years. According to the legend of the country, Korean has a theistic origin. Hawn-woong, God's son, married a bear-lady who was turned into a human from a bear. Thangun, a forefather of Koreans, was born from them. ${ }^{5}$ He established the ancient Chosun Dynasty, the first country in $2333 \mathrm{BC} .^{6}$ Three tribal countries followed: the Unified Shilla Dynasty (57 BC-AD 935), the Koryo Dynasty (935-1392), and the Chosun Dynasty (1392-1910). Korea was invaded by the Japanese who ruled from 1910 to 1945 . Korea was released from Japan during the Second World War. However, soon after, the country was divided by the Korean War in

A Handhook of Korea. 9th ed. (Seoul: Korean Overseas Information Service. 1993). 12.

${ }^{4}$ Korean National Statistical Office. "2002 Statistics." http: www.nso.go.kr eng2002 (accessed July 14. 2002).

'Dongsick You. Christianity and Korean History (Seoul: Yeonsei Universitý Press. 1997). 87.

'Geon Park. 9. 
1950 into two parts: the Republic of Korea, a democratic country in the southern part, and the People s Republic of Korea, a communist country, in the north.

\section{Traits of Korean Culture}

Culture is not developed overnight but is molded through a historical chain that people experience in living, religious practice, wars, politics, and economics.

\section{Vertical Hierarchy}

The fundamental philosophy underlying the Korean culture is Sam-Kang-OhRyun, the teaching of Confucianism. ${ }^{7}$ It includes three major pillars of moralities and five secondary ethics. The three major moralities include the following: (1) The king is the origin of his subjects. (2) the father is the origin of his sons, and (3) the husband is the origin of his wife. Five secondary ethics include the following: (1) There should be intimacy between a father and his children, (2) there should be righteousness between the king and his subjects. (3) there should be distinction between a husband and his wife, (4) there should be a proper order between the old and the young, and (5) there should be trust between friends.

This foundational teaching defines the vertical or hierarchical order between a king and his subjects. father and his children, husband and his wife, and the old and the young. The last one describes the equal relationship between friends. So, most social relationships in Korea are conceived on the basis of a hierarchical order between unequal parties. Traditional Korean society is the vertical authority, which is like a pyramid. It

"The Editorial Office. Jungseon Myeongsimbokam (Seoul: Dong Hwa Sa. 1970). 195-196. 
can be termed a patriarchal society: the father is the highest human authority. It is also paternalistic: inheritance is through the father and the male lineage.

Since all the authority is placed on the man as the family head, women are expected to obey in silence. The status of women in the traditional Korean society is represented by the third article of Oh-Ryun. Under this system, a woman was expected to stay in the home, take care of domestic affairs and seek to please her husband, whom she must obey explicitly.

As Fredrica M. Bunge said, “Throughout traditional Korean society, from the royal palace and central government offices in Seoul to the humblest household in the provinces, the themes of hierarchy and inequality were pervasive. ${ }^{-8}$

\section{Religious Background}

There was orthodoxy in the religious history of Korea. When it lost harmony in religions, the exclusiveness of the doctrines became a weapon used to attack others. To overcome this problem, Koreans have been trying to find wisdom. The main stream of society has adopted an attitude of tolerance among different religions. ${ }^{9}$

\section{Buddhism}

Buddhism arrived in Korea in $\mathrm{AD} 372$, during the Kokuryo Kingdom, in the reign of its seventh king. Sosurim (371-384). It was brought to Korea by a Chinese monk

\footnotetext{
${ }^{8}$ Fredrica M. Bunge. ed. South Korea: A Country Stud! (Washington. DC: American University Press. 1982). 65-66.

'Yihum Yun. Religious Tien of Korean (Seoul: Seoul University Press. 2001). 176-177.
} 
named Sunddo. ${ }^{10}$ Korean Buddhism is indivisibly mixed with shamanism and Taoism, and is known by the term ".supplicating-bless-faith. ${ }^{* 11}$ Kyung-Oh Chae said that Korean Buddhism "is neither a religion nor a system of philosophy. Rather, it has been a culminating form of Korean culture and the arts. .12

Neung-Wha Lee asserts that Korean Buddhism was influenced by the following forms of Shamanistic practice:

1. Mediatorship for rain. capable of being prompted by a spirit ${ }^{\circ}$ s divine power.

2. Mediatorship for the salvation of lost souls from Hell.

3. Mediatorship for fortune. which comes to people through the spirit s power. ${ }^{13}$

In fact, Buddhists make up 25 percent of the Korean population, ${ }^{14}$ and yet of the Korean tangible cultural properties $70-89$ percent is occupied by Buddhism, ${ }^{15}$ a most powerful and profound influence on the religious beliefs of the Korean people.

\section{Shamanism}

Shamanism is an ancient occult religion claiming contact with supernatural entities for a variety of religious or secular purposes. In traditional shamanism, the

\footnotetext{
11.--The Ministry of Culture and Information.- in Religion of Korea. ed. Munhwa Kongbobu (Seoul: Munhwa Kongbobu. 1989). 121.

"Young-Jie Park. "Contemporary Missiology and Ecclesiological Praxis: An Analysis of Church Growth in Korea“ (DMin dissertation, Fastern Baptist Theological Seminary. 1984). 23.

12Kyung-Oh Chae. Thought of Religion: Handbook of Korea (New York: Pageant. 1958). 150.

"Neung-Hwa Lee. Shamanism of Yi Dinast! (Seoul. Korea: The Institute of Korean Cultural Anthropology. 1968). 1.

${ }^{14}$ Yun. 251.

${ }^{15}$ Junsick Choi. Reading Korean Religion as a Culture (Seoul: SaGeo Public Center. 1998). 341.
} 
shaman functions as healer, spiritual leader, and mediator between the spirits and people. $^{16}$

While Shamanism is ubiquitous in the world, it has deeply permeated into the lives of Korean people as the folk religion from ancient times. While current Korean society is westemized, one can easily find many Shamans in Korea. Most of the Korean folk songs. festivals. social practices, family life, and general customs are related to shamanism and represent the great impact of shamanism on Korean culture. Thus, TongShik Ryu asserts. "Korean Shamanism has always managed the people's life and controlled the destiny of Korean culture in syncretism with other religions. ${ }^{-17}$

As regards the influence of Shamanism on Christian life, (1) the motive of the prayer of Korean Christians is very similar to that of the shamanist: "In shamanism, the inception of the blessing is unconditional and pure luck: the spirits may or may not respond, even if the correct Kut is practiced. ${ }^{.18}$ (2) The motive of revival: They (revivalists) were often not really interested in saving souls through their preaching, but only receiving money for their efforts, and they were messengers of hellfire who demanded obedience to themselves, through holding the authority to bless or curse. ${ }^{19}$ Several Korean church growth analysts categorize Yong $\mathrm{Ki}$ Cho, the senior pastor of

\footnotetext{
"John Ankerberg. "Shamanism," Ankerberg Theological Research Institute. http: www johnankerberg.org Articles new-age NA0801W3.htm (accessed July 14. 2009).

${ }^{17}$ Tong-Shik Ryu. The Christian Faith Encounters the Religions of Korea (Seoul: The Christian Literature Society of Korea. 1965), 15.

${ }^{18}$ Sang-Hee Moon. "Shamanism and the Korean Church." Sclesaengmiung (July 1969): 25-26.

19Ui-Hwan Kim. Biblical tiew of Blessing (Seoul: Sung Kwang. 1982). 10.
} 
YFGC, and Ki-Dong Kim, head of the Berea Movement, as the pastors of contextualized shamanistic Christianity. ${ }^{20}$

\section{Confucianism}

The exact arrival date of Confucianism in Korea is uncertain, but it had already acquired a prominent position by AD 372 with the establishment of Taehak ${ }^{21}$ in which five Confucian classics were taught. ${ }^{22}$ While Buddhism was the state religion, Confucianism became the guiding philosophy in the sociopolitical sphere. The founder of the $\mathrm{Yi}$ dynasty selected Confucianism for social and political reconstruction and suppressed Buddhism. From that time on, Confucianism formed the backbone of Korean life. $^{23}$ Confucianism focuses on moral or ethical teaching.

Some said that the main reason Korean Confucianism was strongly influenced by shamanism was that it stressed the veneration of the spirits of ancestors, and fitted in with the deeply rooted desire of the people for prosperity in their earthly lives. ${ }^{24}$ James S.

Gale, a missionary in Korea, said of ancestor worship, "Ancestor worship is the key-stone

${ }^{20}$ Sung-Tae Kim. "Contextualization and Presbyterian Church in Korea" (PhD dissertation. Fuller Theological Seminary. 1991). 35.

"'Ok-la Cheong. ed.. "Korean Confucianism and Conduct of State Affairs." in Special Lecture on Korean Histon: ed. The Compilation Committee of a Special Lecture on Korean History (Seoul: Seoul University Press. 1991). 358.

2-The five Classics are the major resources of Confucianism: The Book of Songs. The Book of History. The Book of Changes. The Book of Rites. and Chun Chu or Spring and Autumn Annals.

"3.Young Ko. "Korean Ancestor Worship in the Light of Biblical Teachings" (DMin dissertation. Adventist International Institule of Advanced Studies. 1992). 40-41.

${ }^{24}$ Sung-Tae Kim. 316. 
of Korea's gateway to the happy lands of prosperity and success" and "Ancestor worship possesses completely the heart and soul of Korean. ${ }^{.25}$

Cho, senior pastor of the YFGC. approved of ancestor worship in a public sermon: "Ancestor worship is nothing but honoring one"s parents. It is quite all right to prepare food, to think of our deceased parents as if they were present. . . It is not sin to bow down to deceased parents. It is not an idol: . . to perform ancestral worship is really a good thing. .26

This does not mean that the SDA Church would adhere to such practices.

Modern Koreans no longer acknowledge Confucianism as a sociopolitical philosophy, but it still rules the Korean thought patterns, customs, and lifestyle. Social stability, respect for learning, and reverence for the aged are the reminiscences of Confucianism. ${ }^{27}$ Confucianism greatly influenced the concept of God to Koreans. Through 明心璂鑑— the precious words which enlighten the heart—the idea of God is represented as follows.

1. Confucius said that the one who does good works is rewarded with a blessing by God; the one who does wickedness is punished by God. ${ }^{28}$

2. Confucius said that the obedient to God will stay alive; the disobedient will perish.

?5 James S. Gale. Korea in Transition (New York: Laymen s Missionary Movement. 1909). 68.

2"Myung-Hyuk Kim. "Historical Analysis of Ancestor Worship in the Korean Church." in Christian Aliernatives to Ancestor Praticess. ed. Bong-Rin Ro (Taiwan: Asia Theological Association. 1985). $164-177$.

?'Ko. 41 .

2ง The Editorial Office. 3. 
3. God of heaven in Soo-Hoon says that God hears like a thunderbolt the whisper between men, and God looks at one s deceiving his heart in the dark room with clearness like the lightning.

4. It is written in the book entitled $l k-J i$ that if evil fills the heart, then God will certainly punish.

5. Confucius taught that if one sins against God. he has nowhere to ask forgiveness. ${ }^{29}$

The review of Confucianism is important to this study as it indicates that it has influenced Korean Christians, and has helped them maintain a concept of God.

\section{Conception of God}

As mentioned earlier, from the ancient time of Korea, the people have kept an idea of God. They had a festival called Younggo where, for several days, they celebrate with eating and singing to worship God. Also. they had another festival to worship God held in October, Dongmeang, and they had a dance called Mucheon. Animism is a type of shamanism. It is a religion that teaches that all things have spirit. ${ }^{30}$ This branch of shamanism is referred to as pantheism. The belief is that there is a creator God who governs the universe and, just as in Christianity. is a solitary Spirit. In Korea. Buddhists and Confucianists also recognize the God of Christianity. So the traditional Korean rite to pray for certain events, such as rain, is made only to God, the solitary Spirit. This concept

\footnotetext{
2"The Editorial Office. 14-19.

"Dongsick You. Religion of Korean and Christianity (Seoul: SamSung Press Center. 1986). 1415.
} 
of God makes it easier for Christianity to be introduced. ${ }^{31}$ Shamanism has also opened the way for people to accept the God of Christianity since shamanists believe there is a God who is highest among all of the many gods. ${ }^{32}$ The story of the founding father of the Korean nation in Thangun mythology has also contributed to the ease of acceptance of Christianity in Korea since it is based on an emotional feeling. often present in Christian witnessing. ${ }^{33}$

\section{Protestantism}

As has already been discussed, Koreans have an idea of theistic origins that has made it easier to present the biblical God and Christianity. The combination of shamanism, Buddhism, and Confucianism has contributed to the contextualization of Christianity with Korean cultural ideas. ${ }^{34}$ Many aspects of church customs and practices are rooted in the culture of Korean practice. Since Korean religious factors include a concept and idea of God which is very similar to Christianity”s God, most Protestant churches have been successful in their evangelistic efforts. They were a very powerful encouragement to those who transitioned into Christianity.

Another reason for the widespread acceptance of Christianity was that the message was not brought by foreign missionaries. but rather. introduced by Koreans. In the case of Roman Catholicism, it came through Lee Seung Hoon, christened by the

\footnotetext{
"Ibid.. 17-22.

${ }^{32}$ You. Religion of Korean and Christianity. 37.

${ }^{32}$ You. Christianin and Korean Histon?. 89.

${ }^{34}$ Ibid. 88-89.
} 
priest M. de Gramont of the Catholic Church in 1784 while he was in China. As soon as he returned to Korea, he shared his belief with two other persons. ${ }^{35}$ Protestantism was also introduced by Koreans, three young men who visited a Christian missionary in China: Lee Eungchan, Kim Jinki, and Lee Seongha. ${ }^{36}$

Korean Protestantism was propagated at the end of the nineteenth century without great resistance because the Yi Dynasty had already opened its door to the Western countries. The first missionaries began to come to Korea in 1885 . Henry D. Appenzeller was one of the first missionaries. ${ }^{37}$ Within twenty years after his arrival, the Korean Protestant Church won more than 200,000 followers. J. Mott. who came to Korea as a missionary in 1907, asserted, "If the Christianity of Chosun (Korea) continues to grow with this speed, it will be the only country among the non-Christian countries which will succeed in the evangelization. ${ }^{\cdot 38}$

The history of Korean church growth is a phenomenon that parallels an explosion, as the following table shows (Figure 1 , below). ${ }^{39}$

As of 1995, the Christian population in Korea ranked at 11,710,000, twenty-five percent of the entire population.

In the process of change from the traditional community to a profit-pursuing society, the church replaced the role of the traditional community. which gave belonging,

\footnotetext{
${ }^{35}$ You. Religion of Korean and Christianity. 119.

"You. Religion of Korean and Christianity. 129.

${ }^{37}$ lbid.. 131.

${ }^{38}$ Kyung-Bae Min. Charch and People (Seoul: Korean Christian Press. 1981). 267.

31) Byungseo Kim. Korean Socien and Pratestant (Seoul: Bookcenter HanU1. 1995). 15-16.
} 
emotional stability, and comfort. ${ }^{40}$ The rapid industrialization resulted in several side effects: (1) people could enjoy enriched living, but there still existed the difference between "the haves and the have-nots"; (2) excessive ups and down of the economy; (3) the slow development of freedom and equality compared to the fast economic growth; and (4) the rapid move of the rural community to cities. This caused the Korean urban people instability, anxiety. and stress. Many people knocked on the doors of churches, in search of the vision, comfort and stability of life. ${ }^{+1}$ This was the main reason for the rapid growth in Korean Protestant churches at that time.

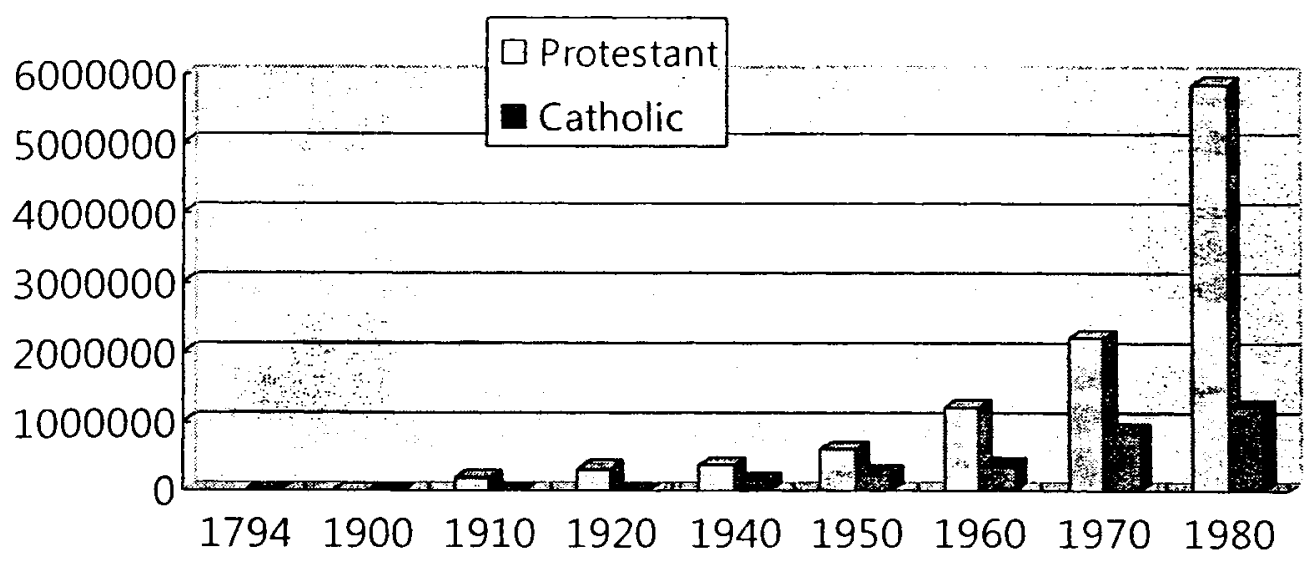

Figure 1. Christian Population in Korea, 1974-1980

\footnotetext{
${ }^{40}$ Mitsui Ken. "The Study of the Comparison between Korean and Japanese Protestant Church Growth" (MA dissertation, Seoul National University. 2000). Korean Abstract.

${ }^{+1}$ Byung-Seo Kim. "A Sociological Understanding on Korean Church Phenomenon." Theological Thoughts 36 (1982): 711 .
} 


\section{Summary}

The Korean people have many disadvantages in several aspects of their cultural and religious environment, as well as negative aspects from history as have been reviewed in this chapter. Korea is one of the smallest countries in the world and yet it is divided into two countries, both with high populations. However, there are some positive aspects and advantages. Koreans have one language and writing system. There is also a legend of the country that the Korean race originated from God. the Creator as God of Christianity, from the beginning of the history of Korea. The concept of God provided wisdom to create harmony among many different belief systems. The review of the history also provides an understanding as to the reason why Koreans could build a big Christian community in such a short time. However, statistics show that the number of Christians is declining in number. This is a big challenge to Christianity in Korea. 


\section{CHAPTER 6}

\section{MODEL CELL CHURCHES IN SOUTH KOREA}

Three model cell churches that have been experiencing successful growth in Korea are researched in this chapter. The focus is on the background, characteristics, and system of the specific church and its affect on its cell ministry.

\section{Global Mission Church}

\section{Background of the Church}

\section{Denominational Background}

The GMC is located in Gyeonggi-do within the circle of the capital city. Seoul, in South Korea. The Church belongs to the Korean Christian Baptist Convention. 'An independent missionary, Malcolm C. Fenwick, who was sent to Korea by the Canadian Independent Baptist Church, arrived in Korea in 1889 and began the Baptist Church. As the Baptist Church increased in number, the church adopted the Korean Christian Baptist Convention as the formal title in $1976 .^{2}$ By 2007 , the membership in the Convention had increased to 800,439 members with 2,550 churches under the supervision of 107 local

\footnotetext{
'Global Mission Church. I Want to Know the Global Mission Church. 4th ed. (Seoul: Global Mission Church. 2007). 4.

'Global Ministerial Leadership Institute. For New Communit! (Daejon: Segee. 2007). 92.
} 
church associations. The number of pastors had reached 4,049 by $2007 .^{3}$ The Convention practices a baptismal ceremony, but rejects infant baptism and the Apostolic Creed. ${ }^{4}$ These differences have been rejected by the Presbyterians who make up the majority of Christians in Korea. However, the Baptist Church and the Presbyterian Church leaders have worked through and accepted their differences and consider themselves sister churches: in other words, they have overcome the obstacles and now have a good relationship.

\section{Brief History of the Church Growth}

Pastor Daniel Dongwon Lee began the GMC with 65 people in November. 1993 and had a founding worship service with 300 church members at the Hall of the Sun Kyong Smart Welfare Center, Suzi, Gyenggi-do, in the first week of January. 1994. The church experienced rapid growth and the church members reached 1,000 by the end of 1994. Due to the increased number of persons attending church, they moved to the Sungsim Building. The attendance soon increased to 4,000. The church adopted the cell church system in June 2001 and entrusted the right to make decisions regarding church practices. such as worship style, mission, community service, and fellowship, to the cell group leaders. To settle the problem of space for worship. the church established a twoway communication system through fiber-optic cables between the Suzi church building and the BoonDang church building and began to worship in two church buildings

\footnotetext{
September 2007.

${ }^{4}$ Global Mission Church. I Hant to Know the Global Mission Church. 5-9.
}

"Christianity Korean Baptist Convention. "Report of Christianity-Korean Baptist Convention." 
simultaneously. ${ }^{5}$ In December 2005, attendance at church reached an average of 18,000 at each service. The membership listed 22,000 regular members. ${ }^{6}$ The leaders of the church then established the goal for 2010 of reaching a membership of 30.000 with 3.000 serving as lay missionaries for the local area and 300 missionaries to go abroad. ${ }^{7}$

The following chart (Figure 2) represents the data of the cell groups of the GMC from 1995 to May. 2007. ${ }^{8}$ It shows the change that took place after 2001. the year GMC changed its ministry system to cell church system. On April 27, 2008. the number of ordained pastors was 35 and the number of assistant pastors was 112."

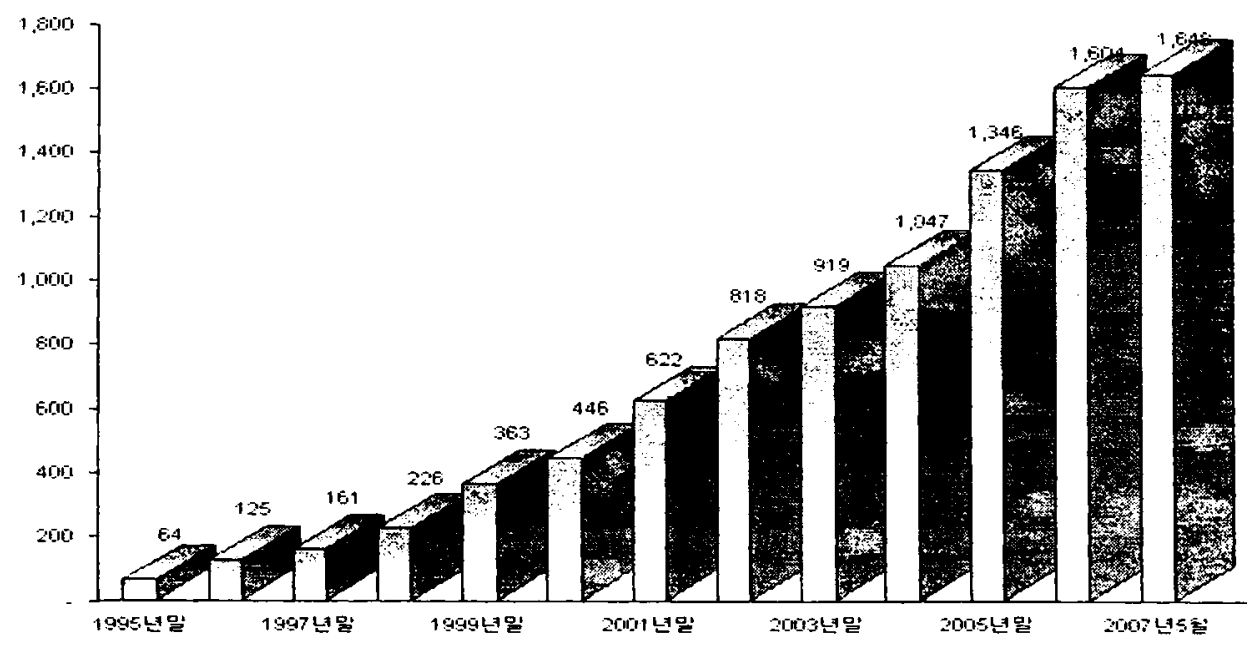

Figure 2. Data of the cell groups of the GMC, 1995-2007.

SGlobal Mission Church. "Global Mission Church of the Healing of Nation and Changing of the World." May 2007. 6-7.

"Global Ministerial Leadership Institute. 93.

?Global Mission Church. "Vision of Jiguchon (hurch in the 21 st Century: Strategy." htp: wWW jiguchon.org english html vision.asp (accessed May 5. 2008).

"Global Mission Church. "Transition of Increase and Decrease of Cell Groups." hup: cell.jiguchon.org html cell_feature.asp (accessed May 6. 2008). 2008 .

"Christianity Korean Baptist Church. "Church Bulletin of Global Mission Church." April 27. 


\section{Cell Strategy of the Global Mission Church}

Even though the church was growing rapidly in numbers, Pastor Lee worried about the quality of the decisions the new members were making. It seemed to him that their membership paralleled that of spectators in a sports stadium, hundreds and thousands of people packed into the stands, everyone having a great experience, but scattering after one or two hours. As he contemplated the meaning of church. people in relationship with God and each other, he decided that what was happening in the large crowds was not the biblical plan. He decided to search for alternatives for sharing the gospel. In June of 2000, during his sabbatical, Lee met Ralph Neighbour, Jr.; Neighbour shared information about a cell church strategy that was working in other parts of the world. Lee then visited what were considered model cell church groups throughout the world. Through this research, he reached the conclusion that nobody had identified a prototype model of the cell church. In fact, without a standard model, he returned to South Korea and decided to launch the cell church system based on his own dream and ideas. In October 2001 he started what he had outlined as a three-year project. The driving force behind his model was his heart-felt desire to tum the attendees and members of his church into participants and actors, real Christians, not just spectators. ${ }^{\text {(1) }}$ Pastor Lee's message to his church was that it needed to become more like the original Christian churches with the mission as described in Paul's book of Acts. the church Jesus established in the first century.

\footnotetext{
"Daniel Dongwon Lee. Green Pasture that He Long For (Seoul: Durano. 2007). 6-7.
} 


\section{System of the Cell Church Ministry}

In this section, the cell church system of GMC is described, including the structure, character, meeting style, and training system. The governing system of the church is identified, as well.

\section{Structure of the Cell Group}

The foundational structure of the cell group of GMC consists of three positions: a shepherd. a pre-shepherd, and twelve individuals. Members of the cell group share seven responsibilities: ${ }^{\prime \prime}$ director of sheep fostering, assistant director of sheep fostering (in charge of evangelism), director of overseas mission, director of domestic mission (in charge of intercessory prayer), director of social welfare, director of educational training. and director of worship. Those carrying these responsibilities build the cell group community.

Seven to ten individuals make up the minimum membership to form a group. referred to as a village group. The village group is made up of the leaders of the various cell churches within a given area. The head of a village group is responsible to provide weekly meetings and takes charge of the meetings. Some of the village groups have overseas cell groups that report to them each week. A given district may consist of seven to twelve village groups. The head of a district division is in charge of the heads of the village groups and oversees bi-weekly meetings of the village leaders. In the district division, there are five departments: a fostering department. a social welfare department. a mission department, an educational training department. and a worship department.

\footnotetext{
"Global Mission Church. Shepherd s Guidebook for 20088. 12.
} 
Each village group leader is in charge of one of the five departments, according to the leader s identified spiritual gift(s). These five departments support the cell group ministry. ${ }^{12}$ The top of the whole system is what is referred to as the cell ministry center of the church. A pastor who is in charge of the cell ministry center carries out the vision and direction that the senior pastor makes and delivers them to the district leaders in the meeting of the district division group. ${ }^{13}$ The cell church system of GMC is summarized in Table 6.

Table 6. Cell Group Organization of GMC

\begin{tabular}{|c|c|c|c|}
\hline Position & Responsibility & Shepherds & Members \\
\hline Cell ministry center leader & Church cell ministry & & \\
\hline District leader & Cell of village leaders & $49-120$ & $343-1440$ \\
\hline Village leader & Cell of cell leaders & $7-10$ & $49-120$ \\
\hline Cell Group leader & Cell members & 1 & $7-12$ \\
\hline
\end{tabular}

At the time of this study, GMC had 17 district divisions, 4 specialized divisions and some youth district divisions. Each district division had two pastors to serve for the divisional ministry. ${ }^{14}$

\footnotetext{
"Global Mission Church. "Ministerial Structure of Cell Church." http: w'w'.jiguchon.org gmc_cell cell_adult l.asp (accessed May 6. 2008).

"Global Mission Church. "Ministerial Function of Cell Church." http: . Ww'.jiguchon.org home.asp (accessed July 20, 2008).

${ }^{14}$ Global Mission Church. "Formation of Cell Church." hıtp: cell.jiguchon.org hıml cell_format3.asp (accessed May 6. 2008).
} 


\section{Characteristics of Cell Church Groups}

GMC has two functioning systems, micro and macro. The small system is the cell church ministry in the home and the giant is the Sunday worship meeting in the church building. The cell church group purposes to fill a spiritual need that the Sunday worship meeting cannot fill. The attendance at the cell group meeting is not optional: It is an indispensable requirement to be a member of the church. The members who are willing to attend the cell meetings have some choices to choose among the specialized cell groups: brothers ${ }^{\star}$ cell group, sisters`cell group, couples ${ }^{\star}$ cell group, hobby cell group. mission cell group. and etc. ${ }^{15}$

The cell group is also characterized by four kinds of distinctiveness as a district cell group, an aged cell group (within 1-10 years in age difference), a special ministry cell group (according to the job area, hobbies, or specific mission goal), and a complex cell group (a mixture of interests). ${ }^{16}$ The cell group system is adjusted according to the needs of the person(s) who join the group. The cell group system of GMC is designed to foster each member through the small meeting in their homes. The existence of cell church groups is a powerful resource for church growth. It is now institutionalized as the central system of the GMC.

\section{Cell Group Meeting}

The members of the cell group meet together once a week in the homes of the members. The procedure and order of the cell group meeting has a fixed format: praising.

\footnotetext{
${ }^{15}$ Global Mission Church. I Want to Know the Global Mission Church. 15-16. World." 9 .

I"Global Mission Church. "Global Mission Church of the Healing of Nation and Changing of the
} 
sharing testimonies, prayer, and discussion for ministry. Sometimes, there is a ceremony of the Lord's Supper and often a meal is shared after the meeting. ${ }^{17}$ Table 7 shows the standard procedure of the cell group meeting. ${ }^{18}$

\section{Table 7. Procedure for GMC Cell Group Meetings}

\begin{tabular}{|l|l|l|}
\hline Greetings to cell church members & Welcome & 10 Minutes \\
\hline Praise as if rain were falling & Praise & 15 Minutes \\
\hline Sharing experience through the textbook & Share Words & 40 Minutes \\
\hline Prayer and care among members & Share Prayer & 15 Minutes \\
\hline All members participate in ministry & Share Ministry & 10 Minutes \\
\hline Finishing in the Presence of the Holy Spirit & Share Wishes & 5 Minutes \\
\hline
\end{tabular}

The meeting is a very practical process of freedom within guidelines. Usually it takes place on Wednesday evenings. However, the meeting date and time can be changed according to the situation of the cell group. For the meeting, a textbook that the church prepared must be used, and the cell group leader must also follow the guidelines of the church to operate the cell meeting. ${ }^{19}$

\section{Training Sỵstem}

In GMC, it is understood that no one can exist without training in the discipleship class because the church vision is that all church members participate in ministry. ${ }^{20}$

${ }^{17}$ Global Mission Church. I II ant to Know the Global Mission Church. 17.

${ }^{18}$ Daniel Dongwon Lee. Leuding Principle for the Cell Church .Meeting (Taejon: Global Ministerial Leadership Institute. 2007). 15.

${ }^{19}$ Global Mission Church. Shepherd's Guidebook for 2008.15.

${ }^{20}$ Global Mission Church. I Ham wo Know the Global Mission Charch. 18. 
There is a regular training course for new members. It consists of a taxonomy system as follows: ${ }^{21}$ New attendees of the cell group take two courses: New Life and New Family; after completing this course, they become family members of the cell group. They then take two training courses: New Community and Cell Church Life. Completion of these courses allows the participants to move to the status of new family servants. At this time, candidacy is automatically recommended to the staff of GMC..$^{22}$ The new family servant. as a settled member of the family, takes two courses: Arrangement of Gift of Cell Church Members and Community Training. and becomes head of a department of ministry in the cell group. The head of the department. as a mature member, takes four training courses: Ministry of the Cell Group Church, Explosion of Evangelism (a bridge of life), Intercessory Prayer, and Arrangement of Gifts of Cell Church Members, and becomes a pre-shepherd. The pre-shepherd, as a ministry worker, takes four training courses: Life of a Shepherd. Cell Group Church, Guiding Principles of Cell Group Meetings. and Open Bible College. and becomes a regular shepherd. The regular shepherds are now considered to be ministers and must learn how to double the cell group; thus. they take the following three courses: Shepherd Clinic, Experiencing God in Church, and Ray-men Missionary College. Having completed these three courses, the individual becomes a rayman missionary trained to evangelize.

\footnotetext{
"'Global Mission Church. "Global Mission Church of the Healing of Nation and Changing of the World." 9.

"Global Mission Church. I Want in Know the Global Mission Church. 24.
} 
The church exercises this very systematic procedure of providing training courses for all new church members in order to prepare each one eventually to become a cell group leader.

\section{Relationship between the Church and the Cell System}

In GMC. all departments of the church cooperate to support the cell church ministry. In other words, the cell church ministry is the central ministry of all the departments of the church, as shown in the following chart (Figure 3). This flow chart dynamically represents the system of the church and cell system. ${ }^{23}$

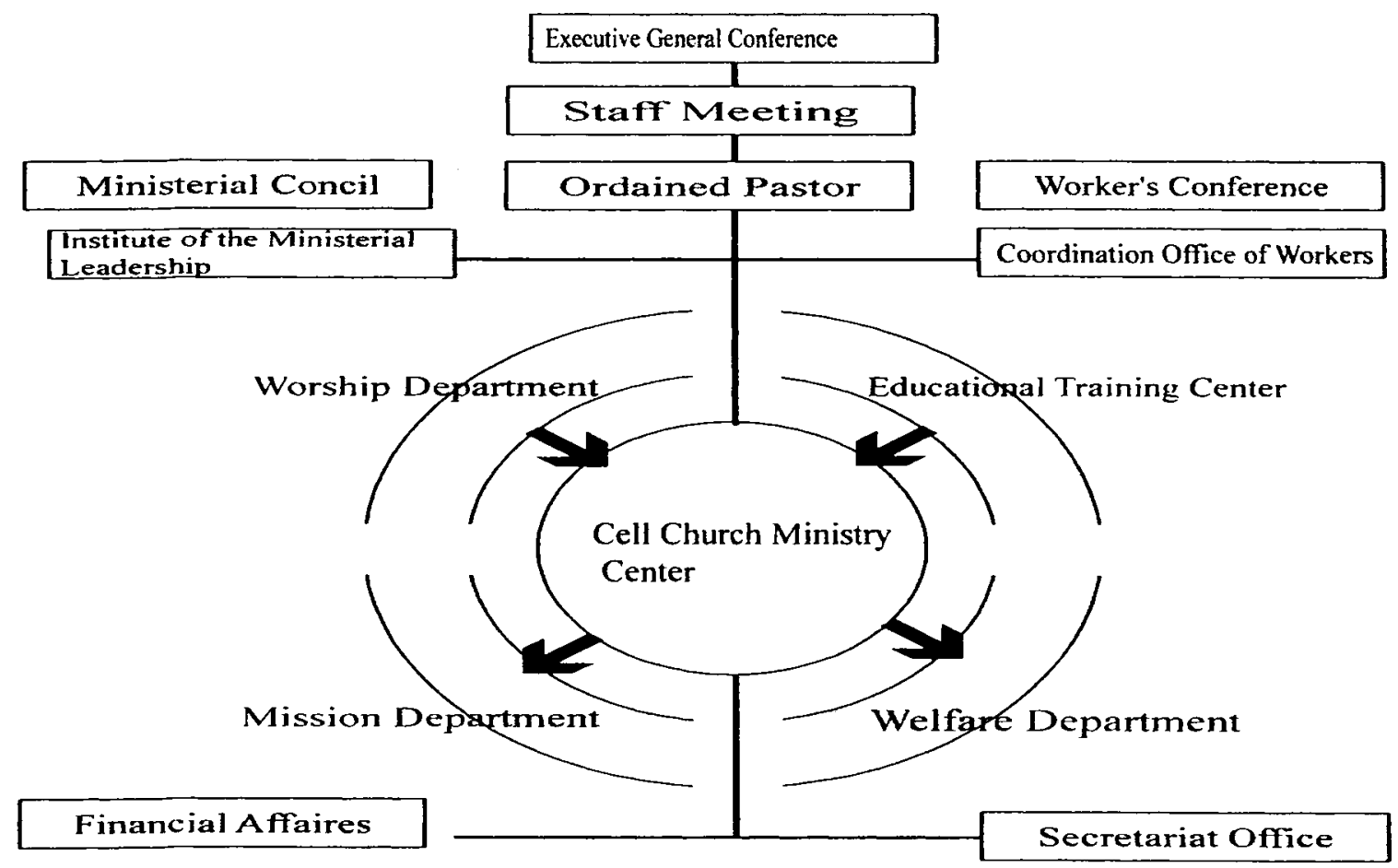

Figure 3. Departmental system of cell group ministry in GMC.

"Global Mission Church. "Organization Chart of Ministry." hup. "www jiguchon.org gmc_m mission_-organization.asp (accessed May. 06. 2008). 
This chart reveals that GMC concentrates energy, time, and power, and all other resources into the cell church ministry. The center of the chart, shaped as a circle, shows the cell church ministry. The cell church ministry has a close relationship with the four departments around it. The Worship Department and Educational Training Department support the Cell Church Ministry and the Cell Church Ministry works through the Mission Department, and the Social Welfare Department to connect to society. ${ }^{24}$ As the chart shows. the cell church ministry is directly related to. and interacts with. all departments in order to function. The foundation of the GMC is a cell church ministry.

\section{Yoido Full Gospel Church}

Background of the Church

\section{Denominational Background}

The YFGC is located in Yoido-dong. in the capital city, Seoul, in South Korea. The church belongs to the Korean Assemblies of God, that is, the Pentecostal Church group. ${ }^{25}$ The Assemblies of God in Korea was begun by a missionary, Miss Mary C. Rumsey, who privately arrived in Seoul in the spring of 1928 from New York, USA. Even though she had graduated from the Methodist Theological School. she worked for the Pentecostal Church and established the first Pentecostal Seobinggo Church in South Korea. The Korean Assemblies of God was organized formally by Missionary Arhber

\footnotetext{
${ }^{24}$ Global Mission Church. "Supporting Ministry for Cell Group." http...cell.jiguchon.org html cell_support.asp (accessed May 6. 2008).

${ }^{25}$ Younggi Hong. Generative Povier to Grow: Yoido Full Gospel Church (Seoul: Institute of Church Growth. 2008). 42.
} 
Cheesnut, sent to the China Assembly of God on April 8. 1953. ${ }^{26}$ The church emphasized the gift of tongues and healing as gifts of the Holy Spirit. Because of these two gifts, the church was initially rejected by other Protestant churches for a long time. ${ }^{27}$ Now the Assemblies of God in Korea is accepted by other churches and has a membership of 2 million with 6.000 pastors serving 3,500 churches in Korea. ${ }^{28}$

\section{Brief History of the Church Growth}

The YFGC began on May 18. 1958, in the living room of Pastor Choi Jashil's house in Seoul, South Korea. There were five attendees. ${ }^{29}$ In three years, the church members grew to 500 members from those first five. ${ }^{311}$ The church moved to Seodaemun-dong in 1961. During the following three years, the membership grew to 3,000. During this time, Rev. Cho established the cell church system. Thirteen years later, the number of church members had increased to 18,000 . The growth was attributed to the practice of a cell church system. ${ }^{31}$ Rev. Cho built a big building to hold 10,000 persons ${ }^{32}$ and dedicated the building on September 23, 1973. The church membership reached

\footnotetext{
${ }^{20}$ Korean Assemblies of God. "Birth of Korean Assemblies of God." http: www.ag.or.kr history" history2-5.html (accessed May 7. 2008).

${ }^{27}$ Korean Assemblies of God. "Establishment of Seobinggo Church of the First Pentecostal Church," http: "ww'ag.or.kr (accessed November 4. 2008).

${ }^{28}$ Allthatnews. "Korean Assemblies of God." http: www:allthatnews.co.kr: news quickViewArticleView.html? idxno=7539 (accessed May 7. 2008).

29 Intemational Theological Institute. ed. Yoido Full Gospel Church 1998-1999 (Seoul: Seoul Malsemsa.
} 1998). 15 .

\footnotetext{
"Hong. Generative Poncer to Grow: 128.

"lbid.. 132-133.

32 Ibid.. 32.
} 
48,975 with 2,055 cell groups by 1977 . The church continually kept growing and, by 1985, there were 503,041 members with 43.834 cell groups. ${ }^{33}$ As of 2007 , membership stands at 830,000 . with seven Sunday services. ${ }^{34}$

Pastor Yonggi Cho retired from the senior pastor`s position and became Senior Pastor Emeritus of the church. After him. Pastor Daniel Younghoon Lee, who was trained by Rev. Cho, succeeded to the senior pastor position on May 21. 2008. The most recent report (2007) states that YFGC has 636 pastors $^{35}$ and operates numerous branch churches, 17 satellite churches. and sends 600 missionaries to 60 countries. $^{36}$

\section{Cell Strategy of Yoido Full Gospel Church}

At about the same time as the membership in the YFGC reached 2,400, Rev. Cho fell ill as he was in the process of baptizing new church members. ${ }^{37}$ In the hospital. reflecting on the situation, Rev. Cho realized the need of some effective strategy to minister to so many. He read about the governing system incorporated by Moses at the suggestion of his father-in-law. Jethro, recorded in chapter 18 of the book of Exodus. ${ }^{38}$ He understood that the pastor must not do all kinds of ministry alone, but must train

\footnotetext{
:3oung Bin Kim. "Pastor Yonggi Cho: 'I Am Not a Supporter of Big Churches. ${ }^{\text {. }}$ Christian Today. hltp: www.chtoday co.kriview htm? code=pd\&id=155077 (accessed May 8. 2008).

${ }^{3}$ Wikipedia. "Yoido Full Gospel Church." hup:" en.wikipedia.org wiki Yoido_Full_Gospel_ Church (accessed October 31. 2008).

${ }^{35}$ Seongkuk Kim. Kibok Beak and Yeon Choi. CEO Yonggi Cho (Seoul: Institute of the Church Growth. 2007). 18.

"Yoido Full Gospel Church. "Ministry Department of the New Church Members." hitp: vfgc.fgll.com Y'66:WY6 3.asp (accessed November 2. 2008).

${ }^{3-}$ Younggi Hong. Rer: Darid Cho is Leadership (Seoul: Institute of Church Growth. 2005). 31.

in Ibid.. 57.
} 
church members and share his ministerial work with lay leaders. ${ }^{39}$ The cell church strategy appealed to him and he applied it in his ministry. The church was changed dramatically. It is believed that without the cell church system YFGC would not have emerged as one of the largest congregations in the world. The cell church group of YFGC follows four functions: (1) worship. (2) training. (3) use of teaching materials, and (4) establishing a mission for the group. ${ }^{40}$ The system supports all departments of the church ministries. The cell church ministry has become a trademark of the YFGC due to the work of Rev. Cho.

\section{System of the Cell Church Ministry}

The YFGC operates a system of cell church ministries as an engine of church growth. It is the strategy YFGC plans to use to increase the membership to more than 800,000 members.

\section{Structure of the Cell Group}

The cell church system of the church is identified with the $5 \times 5$ structure of Jethro of the Bible." The structure is called a "district group." Sometimes it is expressed as a "net. ${ }^{-42}$ As the term of the group was translated into English, it was named "home cell group." It is alternatively called the 5 x 5 system, because group systems are

\footnotetext{
${ }^{39}$ Ibid.. 31 .

4"Hong. Generative Povier to Groni. 159.

"Park Hongrae. Cell Group Cell Church (Seoul: Love Each Other. 2003). 155.

${ }^{42}$ Hong. Generative Pover to Gron: 131.
} 
organized with five multiple houses. ${ }^{43}$ The cell church system is organized as shown in Table 8 below.

Table 8. Cell Group Structure of YFGC

\begin{tabular}{|l|l|c|c|}
\hline \multicolumn{1}{|c|}{ Position } & \multicolumn{1}{c|}{ Responsibility } & Leaders & Families \\
\hline Pastor of Parish & Great Parish & & \\
\hline Head of Parish & Small Parish & 25 & 125 families \\
\hline Head of Zone & District & 5 & 25 families \\
\hline District Group Leader & Cell Group & 1 & 5 families \\
\hline
\end{tabular}

The pattern of the district group is organized according to the geographical division because Rev. Cho believes that the geographic position is critical to providing an efficient and functioning system. However, sometimes it is organized according to the working place or company. ${ }^{44}$ There are 33 large parishes. 309 small parishes, 5.557 zones, and 13,570 district groups in YFGC. ${ }^{45}$

\section{Characteristics of Cell Church Groups}

Pastor Lee says that whoever feels thirsty for and gets a modern passion to grow a church and searches for models cannot escape the cell church system of YFGC. ${ }^{46}$ As he has rightly judged, the YFGC is a model cell church.

${ }^{43}$ Ibid.. 159. 161 .

${ }^{44}$ Paul Yonggi Cho. Hope Minism 45 Years (Seoul: Institute of Church Growth. 2007), 214.

${ }^{45}$ Tae Hyung Lee. "Pastor Younghoon Lee." Yoido Full Gospel Church. http:. 'yfgc. fgtr.com. Y 15 WY15_7_view.asp? num =2\&'num=2\&PAGE=4 (accessed May 3. 2009).

${ }^{46}$ Cho. Hope Ministry 45 Y'ears. 6. 
The characteristics of the cell church system of YFGC consist of two elements: a deliberate process and spirituality. ${ }^{47}$ The system consists of four elements based on Jethro 's model: a pastor system, homogeneity model, balance of self-regulation, and authority. The spirituality consists of six facts: the first fact of success is the vision by the pastor in charge of the church. Second, is baptism by the Holy Spirit of the cell group leader and members. Third, is the internalizing of the vision and philosophy of the pastor by the cell group leaders. Fourth. is sharing life in the Holy Spirit. Fifth. is a vision of the Holy Spirit. Sixth, is a vision of an organizational system by the Holy Spirit. These characteristic elements are considered essential and powerfully inspiring to the system.

Another aspect of the cell church system is women`s leadership. In fact, the idea that leaders of the cell groups were all women in the beginning of YFGC was a very shocking idea. ${ }^{48}$ To collect 20 women for the district group ministry was a revolutionary event in $1964 .^{49}$ Rev. Cho brought his vision before the able cell leaders and entrusted a delegation with power, induced their loyalty, and trained 10 percent of the church members as leaders. ${ }^{50}$

\section{The Cell Group Meeting}

The meeting of the cell church group is designed to meet once a week. The substance of a cell group meeting in YFGC consists of five tasks, in the following order:

\footnotetext{
${ }^{47}$ Hong. Generative Pover to Gron: 160-165.

${ }^{48}$ Paul Yonggi Cho. Successfill Home Cell Groups (Seoul: Seoul Logos. 1997). 21-29.

${ }^{49}$ Hong. Generative Power to Grom: 139-142.

s"Hong. Rev: Cho is Leadership. 70.
} 
(1) to worship God; (2) to foster each other: (3) to build a fellowship; (4) to pray: and (5) to evangelize. ${ }^{51}$ These five tasks are powerful tools to foster the growth of spirituality among the members and prepare them to go out and invite others to join and make the cell group grow. The meeting format is scheduled and takes about 60 minutes, but there is no limited time for praising (see Table 9 below).

Table 9. Procedure of Cell Group Meeting of YFGC

\begin{tabular}{|l|l|l|}
\hline Time of Praising & Sing along & No limit \\
\hline \multirow{2}{*}{$\begin{array}{l}\text { Commendation and } \\
\text { benediction }\end{array}$} & Silent Prayer. The Apostles Creed & 2 Minutes \\
\cline { 2 - 3 } Time of Grace & Praise. Representative Prayer & 7 Minutes \\
\hline Thanksgiving Worship & $\begin{array}{l}\text { Lesson Study } \\
\text { Cooperating Prayer }\end{array}$ & $\begin{array}{l}30 \text { Minutes } \\
5 \text { Minutes }\end{array}$ \\
\hline Fellowship of the Members & $\begin{array}{l}\text { Offerings. Offering Prayer } \\
\text { Prayer for Each other, Introduction of } \\
\text { New Member Praise }\end{array}$ & 2 Minutes \\
\hline Closing & The Lord s Prayer & 13 Minutes \\
\hline Total time & & 60 Minutes \\
\hline
\end{tabular}

The order of meeting ${ }^{52}$ has been kept without change from the beginning of the cell ministry in YFGC. ${ }^{53}$ For the meeting. the church provides a textbook for a six-month course. Fourteen books for 7 years are made as one cycle period for the church members. The course of 14 volumes consists of reading the Bible completely through at least four times. The curriculum is to help members grasp the whole Bible. It is studied systematically according to classified themes. It is felt that this approach encourages

\footnotetext{
${ }^{51}$ Hong. Generative Power to Grom: 123-126.

s2Paul Yonggi Cho. Cell Group Worship Leswon Sudy. (Seoul: Seoul Malsumsa. 2008). 6.

"Cho. Hope Ministry 45 Years. 99.
} 
members to develop a foundation of belief and faith. ${ }^{54}$ The books are compiled in a uniform manner with an established taxonomy.

\section{Training System}

The YFGC operates a "department of new church members" that is to foster and train new believers to settle into the church in an atmosphere of love and acceptance. It is at this stage that newcomers receive training that provides a foundation of belief and knowledge for religious life. The new believer's course consists of courses such as Guidance for Registration, Reception for Welcome. Training. A Great Hope Meeting of the Holy Spirit, Finishing Registration. and Visitation by the Parish. 55

The leader of the district helps the new church member to attend all meetings for one year. The training allows a member to guide the new member through the process and then the goal is for that new church member to guide someone else through the training process. After the first training, there is another three-week program to build a foundation of the faith. Then the program to train one-on-one for five weeks is offered. This five-week training is considered to be a most important task. After twelve weeks. the church provides a baptismal ceremony. ${ }^{56}$

${ }^{54}$ Hong. Generative Power to Grout. 123.

"Y Yoido Full Gospel Church. "Evangelism Department of New Church Members." http : yfgc.fgtv.com common_is openwindow.asp? IFrameSrc=http: nfamily.fgtv.com (accessed August 15. 2008).

5'Hong. Generative Power to Grow: 133-134. 
After baptism. the member can participate in the training of the cell group leadership, there are six conditions to be met in order to be a cell group leader. According to Rev. Cho's principle: ${ }^{57}$

1. The leader must be a Christian woman full of passion.

2. The leader must be selected from women who are models in all aspects.

3. The leader must be chosen from women who are devoted.

4. The leader must be selected from women who are filled with the Holy Spirit.

5. The leader must be a woman who can sacrifice time and material (money).

6. The leader must be a woman who is humble.

According to the introduction of Pastor Hong, the standards of choice are passion, model. and dedication, full of the Holy Spirit, time, material possessions, and humble service.

\section{Relationship between Church and Cell System}

The YFGC is highly organized. The system is more complex than any of the other churches explored in this study. In spite of the complexity and number of departments, all departments cooperate closely with the cell group ministry in order to provide harmony throughout the church systems. Rev. Cho believes that if any pastor wants success in church ministry, there must be a system of cell church groups. He believes that cell church groups provide the life of the church. and he supports the programs with all his energy. ${ }^{58}$ He believes that the cell group system is central to the church and the success

\footnotetext{
${ }^{57}$ Hong. Generative Power to Grow: 148-151.

${ }^{58}$ Cho. Hope Ministry 45 Years. 154. 155.
} 
of the various departments of the church. ${ }^{59}$ As a result. the cell system forms a very strong foundation for the other systems of the YFGC. It is a nucleus of the church community and an important evangelistic tool for the church. To function well, cell ministries have maintained small enough groups to allow communication within the group and with the leaders to prevent bureaucracy from interfering with the smooth functioning of the church. ${ }^{60}$

All departments, such as the Education Department: Media with television broadcasts, internet, and newspaper; Social and Welfare Department; Evangelical Department; Worship Department; and various institutes. and other areas within the church structure support answers and/or content to help the cell group members. Ultimately, all departments are organized to support the cell church ministry. All factions of the church work together to help the cell group accomplish its six-part mission: (1) worship, (2) study of the Word, (3) prayer, (4) healing. (5) fellowship, and (6) evangelism. ${ }^{61}$ The YFGC emphasizes that the best service for the attendees depends on the system set up by the church. It must be organized to touch the people who are attending cell groups and the church meetings. ${ }^{62}$

\footnotetext{
\$9 Ibid., 209.

"Hong. Rev: David Cho s Leadership. 247.

${ }^{61}$ Cho. Hope Ministry 45 Years. 221.

GIbid.. 282-283.
} 


\section{Onnuri Church}

Background of the Church

\section{Denominational Background}

The OC is located in Seobinggo-dong. Yongsan. in the capital city of Seoul in South Korea. ${ }^{63}$ The church belongs to the Presbyterian Church of Korea. Mr. Sangryun Seo became the first Presbyterian Church member as a Korean abroad and came back to South Korea. He established the Song Cheon Church in Hwanghea-do in 1884. In 1885 . Presbyterian missionary U. G. Underwood came to Korea and baptized 32 people. ${ }^{64}$ From that time, the Presbyterian Church has been growing continually and has now become the major Christian denomination in South Korea. The Korean President in office, Myengbak Lee, is a Presbyterian Church member. For every group of 170 protestants, 118 were Presbyterian in $2002 .^{65}$ The membership in the Presbyterian Church numbered $10,956,869$ in $2005 .^{66}$

${ }^{6.3}$ Onnuri Church. "Introduction of the Church." http: www.onnuri.or.krisub. asp? gubun=2101 (accessed August 19.2008).

${ }^{64}$ Data Room of Crossmap. "History of Korean Presbyterian Church," http: crossmap. christiantoday.co.kr data bbs zboard.php? id=data_theology\&page $=1 \& s n l=\&$ divpage $=1 \& s n=0$ ff \& ss $=$ on\&s $c=$ on\&select_arrange $=$ headnum\&desc $=$ asc $\&$ no $=-1203$ (accessed August 21. 2008).

${ }^{65}$ Korean Wikipedia. "Presbyterian Church." http: ko.wikipedia.org' wiki \%EC\%9E\%A5\% EB\%A $\%$ \%C \% EA\%B $5 \% 90$ (accessed August 21. 2008).

${ }^{60}$ Missionmagazine. “2005 State of the Presbyterian Church." http: missionmagazine. com/main php search_view.php?idx=365 (accessed August 21. 2008). 


\section{Brief History of the Church Growth}

Pastor Yongjo Ha began the church with 12 households at Hanman-dong. Seoul in $1984^{67}$ and had a founding worship with 78 church members on October $6,1985 .^{68}$ It was declared to be an Apostolic Church based on the teachings that would have followed Acts 28 had there been a continuation. They called their goal Acts 29 and developed their vision for church groups around that vision. The church membership reached 510 by November 2, 1986, ${ }^{69}$ and the church organized 12 district groups in February, 1986. The title of the group was changed to "Soon" in $1992 .^{70}$

The number of church members increased to 2.571 members by December 23 . 1990. The church made a goal to train 2,000 missionaries and 10,000 lay workers according to the "Vision $2,000 / 10,000 *$ and the church members reached 11,357 on December $29,1996 .^{71}$ The church membership grew to 20,944 by April, 2000 and reached 44,647 in $2005 .^{72}$ The OC has a plan to raise 10,000 leaders of the Soon group and reach 100,000 members by $2010^{73}$

\footnotetext{
${ }^{67}$ Byungkwan Jung. World 17: Mega Church to Lead a Revolution of Gospel (Seoul:Word of Life Co.. 2007). 230.

${ }^{68}$ Onnuri Church. "History of Onnuri Church." http: www.onnuri.or.kr sub.asp?gubun=2104 (accessed August 21. 2008).

(19) Jung. 235.

${ }^{76}$ Sangsoo Lee. Healthfill Church Growth Now: It is Sịt'm (Senul: Word of Life, 2005). 256.

${ }^{71}$ Jung. 236-237.

${ }^{72}$ Onnuri Church. "History of Onnuri Church."

${ }^{73}$ Sangsoo Lee. Healthful Church Growth Now. 11.
} 


\section{Cell Strategy of the Onnuri Church}

Pastor Ha dreamed of a church patterned after Paul's methods. an "Acts church," and, in his heart, believed that the "Soon" ministry would be the basic foundational tool to achieve the vision. The vision found in Acts 29 is based on the vision Jesus gave to "go and make disciples of all nations. ${ }^{.74}$ With this vision as a guide, Yongjo mobilizes lay workers to minister. ${ }^{75}$ The webpage of the OC presents the idea that pastors are not going to change the world; it is the challenge given to lay workers. ${ }^{76}$ His strategy is summarized as follows:

1. Make all church members disciples.

2. Make all church members contribute to the ministries.

3. Make all church members workers in training and mission.

Pastor Ha believes that the "Soon group" consisting of lay workers is a key for church ministry. Therefore. he has poured out his energy to provide lay workers the training necessary for mobilization through the systematic fostering and training of lay workers. The "Soon" system has now become one of the model cell churches recognized worldwide. $^{77}$

${ }^{74}$ Yongjo Ha. Dreaming Acts Church (Seoul: Durano. 2008). 23.

75.Jung. 249. 251.

7"Onnuri Church. "The Church that Onnuri Dreams." hup: wWw.onnuri.or.kr sub.asp? gubun=2102 (accessed August 22. 2008).

${ }^{77}$ Jung. 231 . 


\section{System of the Cell Church Ministry}

Pastor Ha made a special title of the cell church ministry group, the "Soon group." The word "Soon" means ten in Korean, and it is symbolic of the fact that each group has ten members. ${ }^{78}$ The system is described in the following section.

\section{Structure of the Cell Church}

The "Soon" group is a basic unit. It consists of three families and usually they gather in a home. The group is established with three positions. leader of Soon, assistant leader, and Kwoncharl. Kwoncharl is a woman who is to assist the leader of Soon. visit members ${ }^{*}$ homes, report special information regarding the members to the leader of Soon, and exercise intercessory prayer for the group members. ${ }^{79}$ The assistant leader has a mission to assist the leader of a Soon group. Ten to twelve Soon groups constitute a Darackbang group. Three to six "Darackbang" groups constitute a Parish group. The Parish group is called a community. The Soon group system of the OC is organized as the following table shows (see Table 10 below) ${ }^{80}$ The number of the Soon groups multiplied to 1,000 in $2005 .^{81}$

\footnotetext{
${ }^{78}$ Christianity Today, "Soon System of Onnuri Church." http." www'chtoday.co.kr view $\cdot$ htm? $\operatorname{code}=\&$ id $=152012$ \&orderby $=$ no (accessed July 14. 2008).

"Sangsoo Lee, Healthful Church Growth Vow: 261.

"Is'bid.. 264.

"Jung. 249.
} 
Table 10. Cell Group Structure of $O \bar{C}$

\begin{tabular}{|l|l|c|l|}
\hline \multicolumn{1}{|c|}{ Position } & \multicolumn{1}{|c|}{ Responsibility } & Leaders & \multicolumn{1}{c|}{ Groups } \\
\hline Assigned Pastor & Church & & \\
\hline Parish Elder & Parish(Community) & $36-72$ & $3-6$ Darackbangs \\
\hline Leader of Darackbang & Darackbang & 12 & $10-12$ Soons \\
\hline Leader of Soon & Soon group & 1 & $10-12$ Members \\
\hline
\end{tabular}

As seen in Table 10, the "Soon group" system has four levels. The leader of a Soon group works as a minister to train disciples for ministry. The Soon group is the basis of the system used in the OC and is thought to be fulfilling the vision of Acts $29 .{ }^{82}$

\section{Characteristic of Cell Church Groups}

A special trait of the Soon group system is to use men's leadership for the ministry. ${ }^{83}$ It is a different model from Rev. Cho's whose plan which is to mobilize women`s leadership. From the beginning, the OC has kept to the plan of training men for leadership. Even if the man does not qualify for the position, a man will be given the work rather than to ask a woman. To be a leader of Soon, a man must help to train two men in the course entitled "Man-to-Man" and experience fostering their two families. ${ }^{84}$ By restricting the training to men, the approach has had to use a self-regulating strategy that is acceptable to men. ${ }^{85}$

\footnotetext{
82.Jung. 249.

${ }^{8.3}$ Sangson Lee. Stranegr for Church Growth (Seoul: Word of Life. 2006). 1-215.

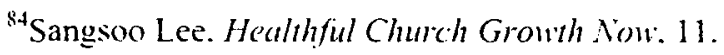

${ }^{85}$ Sangsoo Lee. Strutegy for Church Growth. 5-9.
} 
Men`s leadership training is a centräl strategy used to achieve the "VISION

ACTS 29." It emphasizes team ministry, but the leaders have to be men. It has a deliberate systematic structure. It has become one of the top three model cell churches in South Korea. ${ }^{80}$

\section{The Cell Group Meeting}

The Soon cell group meeting is held every Friday evening in the home of one of the members. The meeting could be changed to another day of the week according to the situation of the Soon group. The meeting place is on a rotation schedule among the Soon group members. The cell group meeting is set up as shown in Table $11 .^{87}$

Table 11. Procedure of Cell Group Meeting of OC

\begin{tabular}{|l|l|l|}
\hline Praise and Prayer & 30 Minutes & $\begin{array}{l}\text { The title of prayer is distributed to the members } \\
\text { of Soon group to pray together aloud and then the } \\
\text { leader or a member of the Soon group prays to } \\
\text { finish the session. }\end{array}$ \\
\hline Sharing Word & 60 Minutes & $\begin{array}{l}\text { It functions with a contemplation/reflection sheet } \\
\text { and ends with a prayer by the Soon group leader }\end{array}$ \\
\hline $\begin{array}{l}\text { Praise, Offerings, } \\
\text { Prayer, Lord s Prayer }\end{array}$ & 10 Minutes & One member of Soon prays for offerings \\
\hline Fellowship & 20 Minutes & $\begin{array}{l}\text { Sharing special information of each family and } \\
\text { church training program with light refreshments }\end{array}$ \\
\hline
\end{tabular}

\footnotetext{
StJung. 230-231.

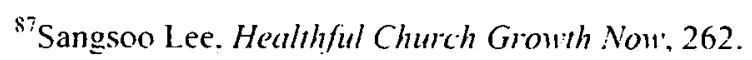


As shown in Table 11, the Soon group meeting sets aside the longest time for meetings compared to other church cell group meetings. It includes a designated time for Sharing the Word. The time of Sharing the Word takes one hour in the meeting. It represents the Word of God as an important resource to enlighten people. The church expects that a new church member can be changed into a mature Christian through Sharing the Word of God. ${ }^{88}$

The textbooks are designed to reproduce another trained layman if he follows all the steps. It consists of the material that Soon members have studied during the previous days of the week. This enables Soon members to have time to understand it in full and be ready to share with others in the meeting. ${ }^{89}$ Even though the meeting is characterized by the sharing of the Word, it is not a strict Bible study. ${ }^{90}$

\section{Training System}

The training system for the leaders of Soon groups is planned according to the philosophy of the church vision. It contains many courses. The first step. seven weeks, is to train the new member to be a registered member of the OC. When this course is finished, a Meeting Festival for the new family is opened. The Meeting Festival is a time to welcome and share congratulations with the new family that will thereafter be considered regular members of the OC. In the meeting, new family members have

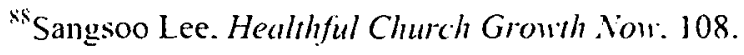

s"loid.. 263.

"Ibid.. 7.
} 
fellowship and share a meal with the local pastors and workers of the community. ${ }^{91}$ As soon as the new church member finishes the course, he will be assigned to a Soon group. ${ }^{92}$ A taxonomy system is applied to the training course (see Table 12). ${ }^{93}$

It was previously mentioned that a special trait of the Soon Group system is men ${ }^{\circ}$ leadership and Pastor Yongjo Ha has been using men as leaders from the beginning of the church. The OC also emphasizes men's leadership; therefore, the church provides a different training course for men (see Table 13 below). ${ }^{94}$

According to the system of Onnuri, every leader must experience the training of new members. ${ }^{95}$ With this training, the church sets up leaders who experience the value of knowing a practical skill and the knowledge of how to win people in the field. Like very small children at the first level, baby school (12-48 month old children) are being trained through this ministry course to be leaders in the future and to become a part of the church"s mission to accomplish the Vision Acts 29. Even a one-month-old baby is included in the training program. ${ }^{96}$

${ }^{91}$ Onnuri Church, "Fostering Ministry." http:; www.onnuri.or.kr. sub.asp?gubun=3106 (accessed August 24. 2008).

?2Jung. 249. 251.

${ }^{93}$ Sangsoo Lee. Healhhfil Church Growth Now: 101

${ }^{14}$ Sangsoo Lee. Strategy: for Church Growth. 1-215.

${ }^{95}$ Sangsoo Lee. Healthful Church Growth Now. 258.

"Onnuri Church. "Ministry of Next Generation." http: w'ww.onnuri.or.kr sub.asp" gubun=2902 (accessed August 26. 2008). 
Table 12. Training Course of Cell Group Leaders of OC

\begin{tabular}{|c|l|l|l|}
\hline Subject & Purpose & Required & Encourage/Option \\
\hline Step 1 & $\begin{array}{l}\text { Basic for } \\
\text { membership }\end{array}$ & QT & $\begin{array}{l}\text {-Onnuri Bible College } \\
\text {-Network, Prayer } \\
\text { School }\end{array}$ \\
\hline Step 2 & $\begin{array}{l}\text { Basic for } \\
\text { membership }\end{array}$ & Man-to-Man Training & $\begin{array}{l}\text {-Onnuri Bible College } \\
\text {-Network, Prayer } \\
\text { School }\end{array}$ \\
\hline Step 3 & Maturity & $\begin{array}{l}\text { Man-to-Man Training } \\
\text { OMC (Onnuri Ministry Conference) }\end{array}$ & $\begin{array}{l}\text {-Family Ministry } \\
\text {-Shing Glory } \\
\text {-Internal Healing }\end{array}$ \\
\hline Step 4 & Maturity & $\begin{array}{l}\text { Training for Evangelism } \\
\text { OHC(Onnuri Holy Spirit Conference) }\end{array}$ & $\begin{array}{l}\text {-Family Ministry } \\
\text {-Shining Glory } \\
\text {-Internal Healing }\end{array}$ \\
\hline Step 5 & Leadership & $\begin{array}{l}\text {-SDS Training Course for Ordained } \\
\text { Deacon } \\
\text {-Women Workers Training Course }\end{array}$ & $\begin{array}{l}\text {-Missionary Training } \\
\text { School }\end{array}$ \\
\hline Step 6 & Leadership & $\begin{array}{l}\text {-JDS (Jesus Disciples School) } \\
\text {-Out Reach }\end{array}$ & $\begin{array}{l}\text {-Missionary Training } \\
\text { School }\end{array}$ \\
\hline Step 7 & Sending & $\begin{array}{l}\text {-OWMTS (Onnuri World Missionary } \\
\text { Training School) }\end{array}$ & $\begin{array}{l}\text {-BEE(Bible } \\
\text { Extensional } \\
\text { Education) }\end{array}$ \\
\hline
\end{tabular}


Table 13. Training Course of Men's Cell Group Leaders of OC

\begin{tabular}{|c|c|c|}
\hline \multicolumn{3}{|c|}{ Self-training Church System for Men`s Leadership } \\
\hline 1 & \multirow{2}{*}{$\begin{array}{l}\text { The church that } \\
\text { Christian men attend }\end{array}$} & Strategy to win unbeliever husband \\
\hline 2 & & Strategy to settle men as Christians in the church \\
\hline 3 & \multirow{3}{*}{ Self-training Church } & Christian Men s Training Strategy \\
\hline 4 & & Christian Men:s Participation Strategy \\
\hline 5 & & Christian Men`s Activation Strategy \\
\hline \multicolumn{3}{|c|}{ Self-training Church that Christian Men Attend: 17 Strategies } \\
\hline 1 & \multirow{4}{*}{ Vision Sharing } & $\begin{array}{l}\text { Understanding the heart of men, successful core element } \\
\text { in renewal of church }\end{array}$ \\
\hline 2 & & Before the first step, discuss with key leadership \\
\hline 3 & & To show that you changed at the first \\
\hline 4 & & Solve the questions of the members: core leaders response \\
\hline 5 & \multirow{9}{*}{ Vision Driving } & Show what they have learned \\
\hline 6 & & Seize hearts of church members and select a key leader \\
\hline 7 & & Organize work team to be confirmed \\
\hline 8 & & Suggest that it is possible to feel changes \\
\hline 9 & & Change training method for men cell leaders \\
\hline 10 & & $\begin{array}{l}\text { Make church members experience establishing church } \\
\text { together }\end{array}$ \\
\hline 11 & & Help members produce enthusiasm to evangelize \\
\hline 12 & & Set up self-study members \\
\hline 13 & & Make them "a lake" church by themselves \\
\hline 14 & \multirow{4}{*}{ Vision Producing } & Know there is no retirement from serving the church \\
\hline 15 & & $\begin{array}{l}\text { Inscribe the love of senior pastor deeply toward church } \\
\text { members }\end{array}$ \\
\hline 16 & & Make unbeliever neighbors advertise your church \\
\hline 17 & & Let no person feel sorry in the church \\
\hline
\end{tabular}




\section{Relationship of Church and Cell System}

The OC developed a very healthy system through four ministry departments:

Worship, Parish, Training, and Ministry. With the professional departments, the church members are transferred into true worshipers - workers filled with the Holy Spirit. and powerful evangelists.

The following chart represents the relationship of the church and the Soon system (see Figure 4 below). ${ }^{97}$

In the chart, a new family Soon group is the center of all training and functioning systems of the church. There is no need to explain the importance of the Soon Group ministry; it is clear from the chart. The Soon group that is caring for a new church member and training him to be a leader is the foundation of the church in this system. All church systems are working in cooperation with the Soon ministry.

The OC had a dream to train 10,000 leaders of Soon groups. Thus, they set up a cell church strategy to reach the goal using three methods: ${ }^{98}$

1. To settle the need of leadership, all members of Soon become leaders of Soon groups.

2. To settle the problem of limited space, establish 30 district churches.

3. To settle the problem of limited ministry, develop a cyber college (internet, digital).

${ }^{17}$ Onnuri Church. "Fostering Ministry Svstem of Onnury Church." http:: file.centr.net sub.asp" mode $=v i e w \&$ idx $=452 \&$ gubun $=0601$ \&gotopage $=3 \&$ Search_type $=\&$ search_andOr $=\&$ search_Keyw
ord $=\&$ sort_num=1 (accessed August 24. 2008).
gubun $=0606$ (accessed August 26. 2008). 


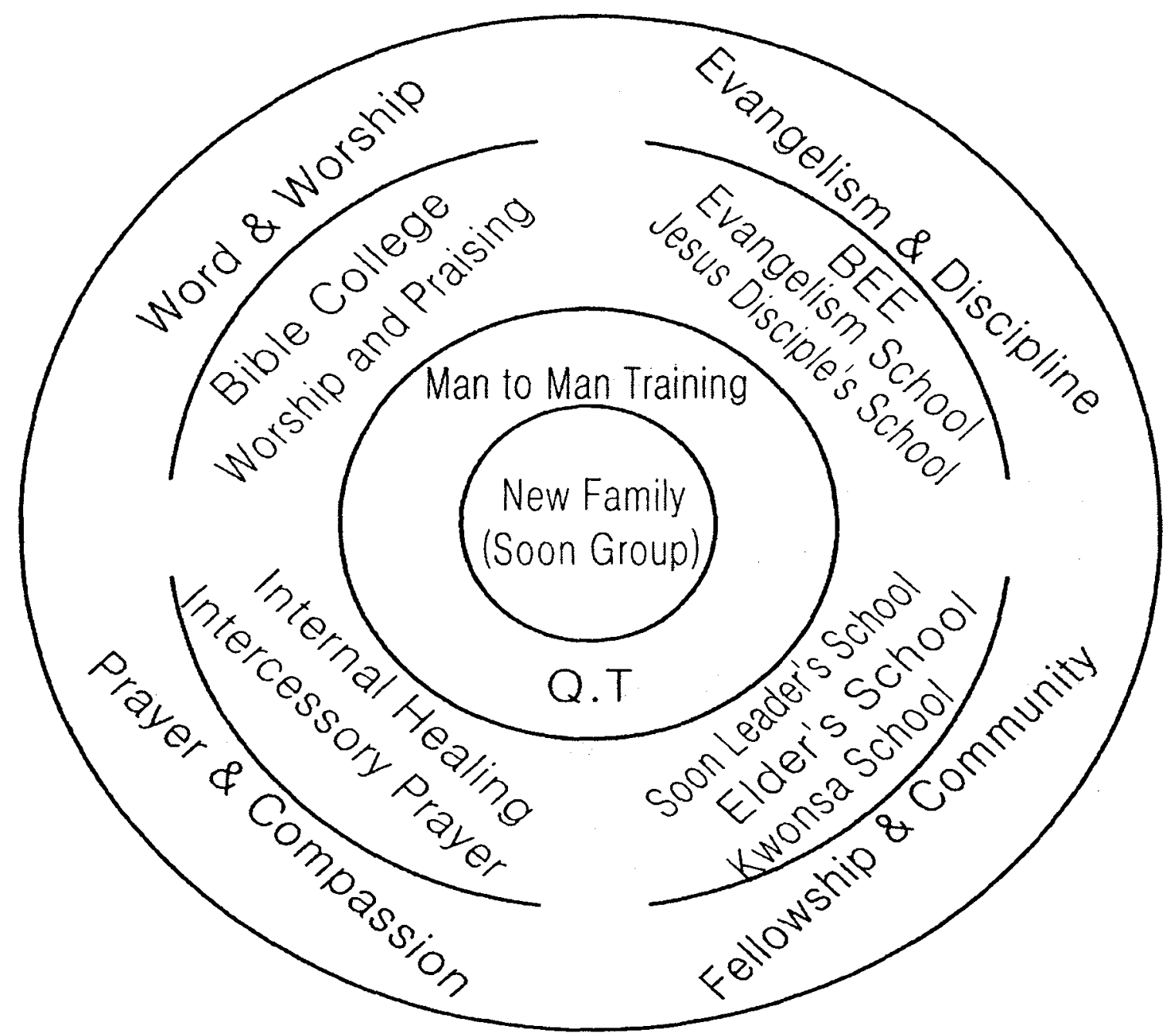

Figure 4. The departmental system with the cell group ministry of the OC. 
All departments of the church cooperate to support the Soon group ministry; therefore, the ministry is based on the support of the church. It is the main tool for evangelism.

\section{Common Characteristics of the Three Churches}

\section{Relationship between Church and Conference}

The three churches are linked to their denominational conference in South Korea and consist of a similar system of a loose cooperation made up of independent churches.

According to the regulations of the Korean Christian Baptist Convention, the local churches register with the main organization and have an obligation to pay monthly dues of 10,000 won to them. ${ }^{99}$ The fee is usually fixed to pay 10,000 won monthly, but some groups give the Conference 1 million won monthly. This depends on the agreement between the group and the Convention. There are also times when a voluntary amount is paid to support special programs. ${ }^{100}$

The Korean Christian Assemblies of God (KCAG) was organized in 1953 using a centralized system. The system was changed into a system of decentralization and independence for the local churches in $1970 .{ }^{101}$ According to the regulation of KCAG, the local churches send only 5/1000 of the local church income to the central Conference. However, if the local church income reaches over 3,000 million won a year, both sides negotiate how much money the local church is to pay. In regards to the pastor`s salary,

"10.000 Won is exchanged with US $\$ 8.19$ in changing value of May 12. 2009.

${ }^{101}$ Pastor Sangkeun Bang. Director of Financial Department. Global Mission Church. interiew by the researcher. June 23. 2009. Seoul. Korea.

${ }^{101}$ Korean Assemblies of God. "Introduction of Constitution of the Church." http: www:kihasung.org (accessed May' 13. 2009). 
the local church pays one-third from the tithe set aside for the pastor, one-third is for the local conference, and one-third to the local church. The tithe of a pastor is paid by his local church. ${ }^{102}$

The OC belongs to the Presbyterian Church of Korea. It is the largest denominational group of Christians in South Korea. However, it is not widely known that the church is Presbyterian. Even Young Jin Cheong, the Soon leader whom I interviewed did not know this; he believes that the OC belongs to a nondenominational organization licensed under the Korea Association of Independent Churches and Missions. ${ }^{103}$ This means that the relationship between the OC and the governing body is based on a looser arrangement than the other two churches studied in this research. In this sense, the OC has more freedom than do other churches. The OC hires 40 percent of its pastors from outside the Presbyterian Church membership. ${ }^{104}$

The three churches have one thing in common. They exercise self-administrative management independently with little, if any, intervention by their governing bodies/conferences. There seem to be no regulations or rules imposed on local churches by the higher level Conferences. The churches exercise absolute power in making decisions by themselves.

In most cases, the only role served by the higher level is that of screening and approving the selection and ordination of the pastors. They exercise the right to approve the acceptance of new members and they issue documents related to all the church groups.

\footnotetext{
1"'Korean Assemblies of God. "Due Fee." http: w'w.ag.or.kr. (accessed November 4. 2008).

${ }^{10.3}$ Cheong Young Jin who is a Soon group leader of the Onnuri Church.
} 
The higher organization has little power over personnel or financial management in the local churches. If a local church has trouble due to the pastor or something related to the pastor ${ }^{\circ}$ position, the Conference can validate that the pastor is registered, but does not get overly involved with the resolution of the problem. As a result, the leaders of the local groups and the leaders of the local churches exercise absolute power over their churches.

\section{Financial Management}

Due to the independent relationship of the local church as it relates to the Conference, the three churches manage 100 percent of their financial matters themselves. even when it comes to the one church where portions of the monies are divided and some sent to the Conference. The churches handle their resources by themselves. Each of the three churches has guidelines for training. but there are no grounds for the Conference to intervene in local financial management. These churches handle all financial resources by their own self-governing system.

The churches encourage contributions by citing the actual use for the monies. There is a system of transparency. There is an established online system in each church for the giving of offerings. ${ }^{105}$ Major kinds of offerings are tithe, thanksgiving, mission offering; and etc. For the convenience of church members who are out of town. the churches have established a digital offering system to give online. ${ }^{106}$ Cell church members make a decision as to how much to support the church ministry by pledging a

${ }^{104}$ Yahoo Korea. “2006 Personage of Religion World." http: kr.blog.yahoo.com lodemtrees 4803 (accessed July 14. 2008).

"Global Mission Church. I Hant Know the Global Mission Church. 21.

${ }^{106}$ Global Mission Church. "Notice of Online Offerings." Financial Department. http: www.jiguchon org home.asp (accessed July 20. 2008). 
donation every year and most follow a budget percentage plan: 50 percent for mission, 25 percent for social welfare, and 25 percent for the ministry of the cell itself. Cell church members can use the local budget to help someone with special needs. The cell group members also donate monies for special events and 50 percent can be used at a given time for celebrations or sharing the expenses when someone loses a loved one. ${ }^{107}$

The GMC has written right into their local church regulations (Management Regulations: Clause 1, Article 2) that the management of offerings is fully operated by the church itself.

The YFGC also manages its own financial resources, like GMC. The YFGC and KCAG are somewhat similar. They each engage financial administration workers to oversee the finances, but there is no other intervention by anyone from outside. The local churches make all decisions about how to use the income of the church.

The OC is not very different from the other two churches in that members of the Soon group give monthly offerings, but in this organization, Kwoncharl ${ }^{108}$ manages the offerings and uses 40 percent directly for the ministry of the Soon group. Thirty percent of the offering is sent to the main church and 30 percent to the Parish. ${ }^{109}$

The same fundamental system of the three churches is characterized by a selfgoverned management style. This approach seems to empower the local members, and they still support the administration team as they plan for church growth. This financial

\footnotetext{
${ }^{1117}$ Global Mission Church. "QA for Cell Group Ministry." Ministry of Cell Group Church. http cell.jiguchon.org html cell_faq.asp (accessed May 06. 2008).

${ }^{1110} \mathrm{~K}$ woncharl is a position to help Soon group leader. the position is under the deaconess.

${ }^{1109}$ Sangsoo Lee. Healthful Church Growth Now. 261.
} 
system allows members to make and support local church projects in a timely manner. It seems to provide a feeling of control over their own ministry for better ministry, and allows the church to change investments quickly according to the needs of the ministry.

\section{Personnel Management}

On the basis of the church system, the GMC exercises the power of personnel management to hire and release workers and pastors without any intervention by the governing body. A personnel committee of the church works on personnel management. However. Pastor Lee has the right to confirm the decision that the personnel committee made to hire or fire workers. Therefore, Pastor Lee exercises absolute power in personnel management. It is rooted in the regulation of the GMC, Regulation of Personnel Management (Clause 1, Article 6).

According to the Constitution of the $\mathrm{KCAG}$, the senior pastor in charge of the YFGC becomes the chairman of the church committee that includes personnel and financial management. The senior pastor appoints more than five people to the church committee that is organized with more than ten people. ${ }^{110}$ The senior pastor has full power to control all church administrative management; therefore, he can choose an associate pastor by himself. ${ }^{\prime \prime}$ An assistant pastor does not have the same power as the associate and cannot be assigned to the senior pastor's position except when the senior pastor retires. The official term of the assistant pastor is one year; however, it is possible

\footnotetext{
"1'Heeyoul Chang. Constitution (Seoul: Publishing Department of Christianity Korean Assemblies of God. 2007). 60-61.

"Constitution of Christionity Korean Assemblies of God (Seoul: Publishing Department of Christianity Korean Assemblies of God. 2007). Vol. 3. Chap. 6. Art. 38.
} 
to be reappointed each year. If the senior pastor resigns, all workers on regular salary must automatically resign with the pastor. ${ }^{12}$ Under the regulation, the senior pastor of the YFGC can exercises exclusive power to control the church.

In the case of the OC, the secretarial team that assists the senior pastor makes decisions regarding personnel management. This system also allows the senior pastor Ha to hire or fire workers according to his decision. The position of the senior pastor of $\mathrm{OC}$ is the highest authority to manage the personnel system of the church.

The position of the senior pastors is like the CEO position of a company. They practice a very powerful leadership and can make decisions related to personnel management.

Rev. Cho is compared to CEO Geonhee Lee, president of the Samsung Company, who achieved a great success in the business world. ${ }^{113}$ In fact, he does work as a CEO, who is working for a business, having powerful leadership and the authority to make decisions. All three pastors exercise the same leadership and right to make decisions for church ministry in their churches.

\section{Ministering Period of the Pastors}

With the independent church system. the pastors who are ministering for the cell churches can keep their senior pastor's position for a long period without challenges.

Pastor Lee has served the GMC since 1993, the very beginning of the church, until now-sixteen years. Rev. Cho ministered for fifty years in the YFGC from 1958 to

\footnotetext{
"Constiution of Christianity Korean Assembliex of God. Chap. 6, Art. 39.

${ }^{11.2} \mathrm{Kim}$. Beak. and Choi. 45 .
} 
2008 without changing his position, and retired from the YFGC that he founded. Pastor Ha also has been working in the OC from the establishment of the church until nowtwenty-five years. The system of cell churches allows a long period of service for its senior pastors. The long period of ministry in the same church allows the senior pastor to have enough knowledge about the church, its structure, system, and people, and keep a master plan without changing. It appears to be a powerful resource for successful ministry of the churches.

\section{Remuneration of Senior Pastors}

The churches decide the senior pastor's salary by themselves. The salary that the pastor receives depends on the financial situation of the churches. Small-size churches of their denomination offer very little remuneration to their pastors.

Professor Hogyun Shin studied 52 non-independent churches and 40 large churches that have more than 1,000 church members. ${ }^{114}$ The churches are located in Daegu, the third largest city in Korea. According to his research, the difference in church budget between a large independent church and a non-independent church is 130 times. The difference of salary of the pastors in these churches was seven times. Pastors who are ministering in large churches receive $61,200,000$ won; pastors who are ministering in small churches receive $8,880,000$. The average number of church members in a large church is 1.640 , but only 13 in a non-independent church.

According to some information, Rev. Cho received $300,000,000$ won a year.

Other information says that Rev. Cho received 1,100,000.000 won as his salary, but there 
is no exact information. To research a pastor s salary is very difficult because nobody knows about it except the financial worker who deals with church offerings. Sometimes, the members of the church administration do not know it. ${ }^{115}$ As this study is proceeding. the researcher also experienced the same situation. Mega churches. such as the GMC. the YFGC, and the OC do not release information on the pastor's salary. How'ev'er. Protestant churches usually pay a pastor`s salary according to the church`s financial situation. The salary system is operating in a capitalism mode. If a pastor achieves great success in the church ministry, his salary goes up. Therefore, there are big differences among pastors who are ministering in mega churches.

\section{Summary}

The three cell churches have their own approach to cell church ministry. Even though certain differences exist among the churches, the following factors are similar among them. (1) The groups experienced very fast growth. (2) The pastors had a conviction that cell group ministry is a critical tool in their ministry of the churches. (3) The cell group titles are different but they function the similarly. (4) Cell ministry is the center of the ministry of the churches. (5) The cell groups that they are operating are systematically organized. (6) The training system of the leaders is very logical and taxonomical. (7) The three cell churches operate independently from their higher organizational conferences in personnel and financial management. (8) The pastors keep

\footnotetext{
${ }^{11 H}$ Hogyun Shin. “An Exploratory Approach on the Realities and Breakthroughs of Korean Church Polarization.. A Sully of Logos Manuge'me'm 5. no. 1 (2007): 1-19.

115DangDangNews. "Salary of Somang Church." Gyuhock Hwang"s Ecclesian News. hup: "ww dangdangnews.com new's aricleView html'? idxno=3403 (accessed Iune 3. 2008).
} 
the senior pastor's position for long periods of time in the same church. (9) They receive a higher salary according to the achievement made in growth.

From what has been discussed above, it can be concluded that the pastors exercise very powerful leadership and achieve their dreams successfully through cell group ministry. 


\section{CHAPTER 7}

\section{DISTINCTIVE CHARACTERISTICS OF THE SEVENTH-DAY ADVENTIST CHURCH COMPARED TO THE THREE MODEL CELL CHURCHES}

This chapter presents a brief background of cell ministry and the system of the SDA churches in South Korea. It focuses on identifying the distinctive characteristics of KDA churches in comparison with the systems of the three model cell churches.

\section{Brief Background of the Seventh-day Adventist Church in South Korea \\ Historical Background}

Adventism was introduced into Korea in 1904 by two Koreans. Mr. Eung Hyun Lee and Mr. Heung Cho Son, who returned from Japan. When they stayed in Japan. processing applications to emigrate to Hawaii, they found "the Seventh-day Sabbath, Christ's Second Coming Church, ${ }^{-1}$ and met Hidero Kuniya, an Adventist Japanese evangelist serving at Kobe in Japan. They studied the Bible with him and were baptized at Nunobiki Falls. After they were baptized. Eung Hyun Lee left for Hawaii, but Mr. Son s application was rejected by the U.S. immigration office, and he was obliged to

\footnotetext{
'Yung Lin Lee. Histon of Korean SD.4 Church (Seoul: Sun Mỵung Cultural Press. 1968). 30.
} 
return to Korea. On board the ship home, he met Mr. Hyung Joo Im, a Methodist; ${ }^{2}$ and shared the Adventist message with him. ${ }^{3}$

Mr. Im accepted the message and came back to Korea and worked together with Mr. Son sharing the message of the SDA Church. Through their efforts, 200 people accepted Adventist message. At last, they invited Hide Kuniya to Korea. Hide Kuniya came to Korea with Pastor F. W. Field who was in charge of the Adventist mission work in Japan. These two leaders came and met with the people Mr. Im and Mr. Son had been working with. and they baptized 71 individuals and organized several churches. ${ }^{4}$ The first missionary to come directly to South Korea, Pastor W. R. Smith, established a mission headquarters in Sunan of Pyungan-do in the North Korean territory. The number of SDA ${ }^{\circ}$ in Korea continued to grow. By 1919, there were 1.021 baptized members with 24 churches, 1,681 attendees. and 131 gospel workers with three mission fields under one union mission by 1919. Now, the SDA Church in South Korea has 5 conferences. ${ }^{5}$ with 198 congregations and 707 churches. There is a total membership of 203,517 with 886 pastors in what is now called the KUC.

2History of Korean Adventist Church. "Beginning of Korean Adventist Church." http: www adventistkr.org si_intro_pages c_a.html (accessed September 18. 2008).

"Gil G. Fernandez. ed.. Light Dawns over Asia. Adrentism 's Story in the Far Eastern Division (Silang. Cavite. Philippines: Adventist International Institute of Advanced Studies Publications. 1990). 66.

${ }^{4}$ Yung Lin Lee. 35.

${ }^{5} \mathrm{KUC}$ consists of five conferences: East Central Korean Conference. West Central Korean Conference. Southeast Korean Conference. Middle West Korean Conference. and Southwest Korean Conference.

"Korean Linion Conference J'arbook (Seoul: Signs of the Times. 2008). 6. 


\section{Growth of the Seventh-day Adventist Church}

The number of baptisms and pastors in the KUC has steadily increased during the last 20 years, from 1989 to 2008 (see Table 14 below). The number of baptisms yearly in the KUC increased from 5,588 to 6.373 . During this period, the number of pastors increased from 426 to 892 . While the ratio of the number of baptisms increased by 14 percent. the number of pastors, increased by 109 percent. The number of baptisms for the 20 years is 6.379. On average. each pastor baptized 13.11 in 1989 and 7.14 in 2008 . The data show that KUC churches have been declining steadily in growth during the last 20 years.

In comparison with this data. the growth of the model cell churches was much faster and the numbers higher than the KUC achieved. Table 15 (below) compares the four largest Adventist churches in the West Central Korean Conference (WCKC) and East Central Korean Conference (ECKC), located in the Seoul area, with the model cell churches. also located in the Seoul area. As the table shows, the largest Adventist churches are growing very slowly in comparison to the three model cell churches. ${ }^{7}$ The YFGC gained an average of 16,600 members per year, while the Mukdong Church gained 25.59. GMC gained an average of 1.370 members yearly, while Seoul Joongang Church gained 11.7 members. This comparison reveals that the system of the three cell churches is more effective for church growth.

The ministry years of the churches counts only the working period after a pastor was appointed for the church. Seokwon Kang. Church Histon of Irest Central Korean Conference of Serienth-da! Adrentists (Seoul: DuGyeong. 2008). 276. 611: Hyuckwoo Kweon. Church Histon of ECKC of SD.A (Senul: Samyoung. 2007). 183. 372. 
Table 14. Number of Baptisms and Pastors, 1989-2008

\begin{tabular}{|c|c|c|c|}
\hline Year & Number of Baptisms & Number of Pastors & $\begin{array}{c}\text { Average Number of } \\
\text { Baptisms per Pastor }\end{array}$ \\
\hline 1989 & 5.588 & 426 & 13.11 \\
\hline 1990 & 6,801 & 470 & 14.47 \\
\hline 1991 & 6,104 & 507 & 12.00 \\
\hline 1992 & 6,356 & 535 & 11.88 \\
\hline 1993 & 6,158 & 578 & 10.65 \\
\hline 1994 & 6.340 & 624 & 10.16 \\
\hline 1995 & 6,075 & 649 & 9.36 \\
\hline 1996 & 6,082 & 678 & 8.97 \\
\hline 1997 & 5,974 & 715 & 8.35 \\
\hline 1998 & 6,648 & 722 & 9.20 \\
\hline 1999 & 6,746 & 749 & 9.00 \\
\hline 2000 & 6,092 & 775 & 7.86 \\
\hline 2001 & 5,924 & 814 & 7.27 \\
\hline 2002 & 5,985 & 828 & 7.22 \\
\hline 2003 & 6,823 & 838 & 8.14 \\
\hline 2004 & 6,911 & 860 & 8.03 \\
\hline 2005 & 6,931 & 878 & 7.89 \\
\hline 2006 & 7,144 & 885 & 8.07 \\
\hline 2007 & 6,524 & 886 & 7.36 \\
\hline 2008 & 6,373 & 892 & 7.14 \\
\hline
\end{tabular}


Table 15. Church Members and Ministry Years of SDA and Cell Churches

\begin{tabular}{|l|c|c|c|}
\hline \multicolumn{1}{|c|}{ Church } & $\begin{array}{c}\text { Ministry Years } \\
\text { (Year) }\end{array}$ & $\begin{array}{c}\text { Number and Year the } \\
\text { Number was Highest }\end{array}$ & $\begin{array}{c}\text { Average Yearly } \\
\text { Growth }\end{array}$ \\
\hline GMC & $16(1993-2008)$ & $22,000(2005)$ & 1,375 \\
\hline YFGC & $50(1958-2008)$ & $830.000(2007)$ & 16,600 \\
\hline OC & $24(1984-2008)$ & $44.670(2005)$ & 1,861 \\
\hline SDA Mukdong & $27(1979-2006)$ & $637(2006)$ & 25.9 \\
\hline SDA Youngdong & $29(1977-2006)$ & $516(2006)$ & 17.79 \\
\hline SDA TaeNeung & $48(1960-2008)$ & $768(2009)$ & 16 \\
\hline SDA Seoul Joongang & $98(1909-2008)$ & $1,150(2009)$ & 11.73 \\
\hline
\end{tabular}

\section{Cell Strategy of the KUC}

The Church Mamual for the KSDA churches includes a suggested guideline for developing and maintaining cell groups. According to the guidelines, the local church pastor should organize all church members into cell groups for ministry. The idea is very similar to the concept of the model cell church systems. The manual describes these groups as "the life of the body... . If the cell dies, at last the body dies. If the cell is healthy, the body is also healthy. Cells are multiplied and the body also experiences growth. ${ }^{.8}$ This description presents the cell church strategy through the symbolism of a cell of the human body.

The Manual suggests that members establish a strong friendly group that consists of individual members who come together for one or two hours. The format of the meeting consists of four parts: sharing. Bible study, prayer. and evangelism. ${ }^{9}$ The idea matches the practice of the cell group ministry exactly. With this basic understanding. the 2008). 118.

"Serenth-da! tdrentist Church Manual: Korean Lnion Conference' (Seoul: Signs of the Times.

"Ibid.. 119. 
KUC of SDA s serving South Korea has been encouraging pastors and members to launch cell church groups, but it is either not happening or not working. The basic instructions are similar to those given by churches with model cell church groups.

\section{System of the Cell Church Ministry}

Comparing the KSDA churches and the Korean model cell churches has identified a number of differences. The model cell churches tend to operate the standard model cell group that involves the whole church. It is a very economical, effective. and systematic strategy for a large church system. However, KSDA churches have not adopted a standard structure for the small groups. Each church establishes its own style of structure. Therefore, each church operates a different small group system, which may or may not meet the criterion for cell church groups. Table 16 presents the group style of the KSDA Church and the three model cell churches.

Table 16. Type of Cell Group Practiced

\begin{tabular}{|c|c|c|c|c|}
\hline Clause & KSDA & GMC & YFGC & OC \\
\hline Group Style & $\begin{array}{c}\text { No Standard } \\
\text { Group }\end{array}$ & Cell Group & $\begin{array}{c}\text { District Cell } \\
\text { Group }\end{array}$ & Soon Cell Group \\
\hline
\end{tabular}

As the previous chapter revealed. the model cell churches manage a systematic training system with groups stylized according to the pastor's philosophy of cell group ministry. The model cell groups are programmed logically. step-by-step, according to the needs of the trainee who is participating in the training course and planning to assume future leadership of a cell group. However. KSDA has no deliberate plan, no regular program. and no system set up to train cell group members to be leaders in the future. 
Each church decides the group style, plan, ministry and project by itself. There is no specific model structure to follow.

Table 17 (below) summarizes the characteristic system of the training for leadership of cell groups. In the model cell churches, the same program and training course are applied for thousands of groups. One format of a group and one format of materials are used for the whole body of the church. It is very convenient for the leadership to control and it is also very economical.

\section{Table 17. Training System of Cell Group Leaders}

\begin{tabular}{|c|c|c|c|c|}
\hline Clause & KSDA & GMC & YFGC & OC \\
\hline Programs & None & Systematic & Systematic & Systematic \\
\hline Course & None & Taxonomical & Taxonomical & Taxonomical \\
\hline
\end{tabular}

\section{Description of the Present Small Group Ministry}

KSDA churches have the right idea and the guidelines in the manual for small group ministries are helpful. The five local conferences have been cooperating with each other and with the KUC to build a small group ministry system. According to the plan set up and presented by the KUC, each local conference has set up what they felt were model small groups. ${ }^{10}$ See Table 18.

\footnotetext{
"'2008 Business Project of Southeast Conference of SDA in Korea. 24.
} 
Table 18. Data of Small Group of KSDA, 2005-2009

\begin{tabular}{|c|c|c|c|c|c|}
\hline $\begin{array}{c}\text { Model Churches in Each } \\
\text { Conference }\end{array}$ & 2005 & 2006 & 2007 & 2008 & 2009 \\
\hline Total in KUC & 15 & 25 & 35 & 50 & $\begin{array}{c}\text { All } \\
\text { churches }\end{array}$ \\
\hline $\begin{array}{c}\text { Financial Support for } \\
\text { Each Model Church by } \\
\text { KUC and Conference }\end{array}$ & $\begin{array}{c}1,000,000 \\
\text { Won }\end{array}$ & $\begin{array}{c}1,600,000 \\
\text { Won }\end{array}$ & $\begin{array}{c}1,200,000 \\
\text { Won }\end{array}$ & $\begin{array}{c}800,000 \\
\text { Won }\end{array}$ & None \\
\hline
\end{tabular}

The KUC and local conferences encourage the model churches with some financial support. This plan to establish a cell group ministry model began by building three model churches in each conference from 2005. and reached ten model churches in each conference. The KUC provided a cell group crusade meeting through satellite TV and internet network every year. According to the original plan to build a small group system. the number of model cell group churches reached fifty throughout South Korea. The project to spread the model system to all of the churches in the KUC has not happened, even though it is almost the end of the projected period when all churches were to have adopted the cell groups.

The report of the Mission Department of the KUC in March 2009 showed that the number of organized cell groups in the five conferences in the KUC is 3,466 , but the number of activated groups is $2.383 .{ }^{\text {" }}$ However. research for this study revealed that even the number of activated cells includes some groups with very low attendance. The data presented by the KUC indicates that rather than having an increase in baptisms. there has been a consistent decline. The statistics indicate that there were 6,931 baptisms in

\footnotetext{
"First Term-End Report of 2009. Mission Department of KUC.
} 
$2005,7,144$ in $2006,6,525$ in 2007 , and 6,373 in 2008 . The average number of baptisms per pastor is also declining. The average numbers that pastors baptized dropped from 7.89 in 2005 to 7.14 in 2008 .

The cell groups are not functioning as the original cell church group modeled. The plan to build a cell church system throughout all of the Korean Adventist churches has failed. They are just nominal small groups and do not function as a typical cell group system. The ratio of church growth for twenty years of the KUC reveals failure. The plan to establish cell church groups in the Korean Adventist churches by the end of 2009 seems not to have happened.

\section{Relationship between Church and Cell Group System}

The cell church group system has a department at the KUC. It has been considered to be one of the many departments supported by the KUC. The departmental structure is shown in Figure $5 .^{12}$

As the table shows, the cell group ministry belongs to the Mission Department. Cell groups cannot work as a central system or even influence other church departments in the way it has been structured. Contrary to this system. all departments of the three model cell churches are working for and through the cell group ministry. The cell group ministry is treated as the main body of the church ministry and all the departments interact with and support the cell group ministries. As a result. the program is flourishing and the churches are experiencing continued growth in membership.

\footnotetext{
${ }^{2}$ Korean Seremh-da! Adrentist Yearbook (Seoul: Signs of the Times. 2009). 15.
} 


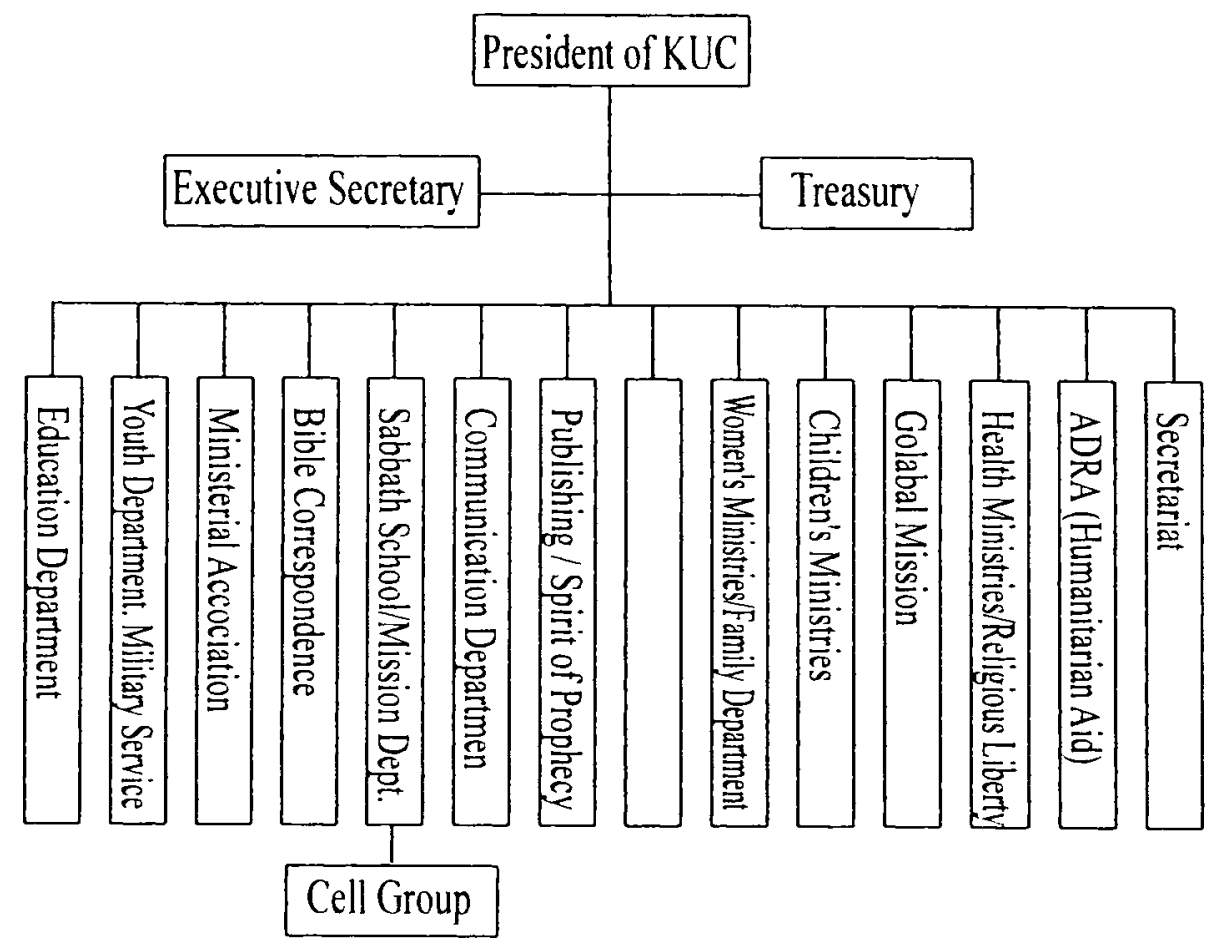

Figure 5. Departmental system of KUC.

The three model cell churches adopted the cell group ministry system as a critical strategy for church ministry, whereas the SDA churches do not seem to have a working model of a successful cell group. It seems that the KUC considers cell group ministry to be a subordinate system to assist church ministries rather than a central component of evangelism. Table 19 illustrates the relationship of the particular churches in this study and cell church ministry. comparing the model cell churches and those of the SDA Church.

Table 19. Position of Cell Group Ministry in the Churches

\begin{tabular}{|c|c|c|c|c|}
\hline Clause & SDA & GMC & YFGC & OC \\
\hline $\begin{array}{c}\text { Position of } \\
\text { Cell Group } \\
\text { Ministry }\end{array}$ & Part of Church & $\begin{array}{c}\text { Central System } \\
\text { of Church }\end{array}$ & $\begin{array}{c}\text { Central System } \\
\text { of Church }\end{array}$ & $\begin{array}{c}\text { Central System } \\
\text { of Church }\end{array}$ \\
\hline
\end{tabular}


The fact that the Adventist churches view cell groups as just one of many ministries, a part of the church and not central to all ministries, may be one of the reasons that the cell groups have not succeeded.

\section{Relationship between Local Church and Conference}

The political System of KSDA churches in Korea is a representative system. This system acknowledges the authority of church members and entrusts the authority to the representatives and the board of the church, conference, union conference and General Conference (GC). According to the Church Manual, the KSDA Church structure is organized into the following four constituent levels: ${ }^{13}$

1. The first level is a local church or a company that is organized and made up of individual believers. The local church is organized by the ordained pastor through the decision of the executive committee of the conference. ${ }^{14}$

2. The second level is a conference, a local field or a mission that is organized and made up of the local churches according to state. province, or territory. It is organized by the delegates selected from all of the churches in the territory.

3. The third level is either a union conference or union mission that is organized and made up of conferences. missions, or fields in a large territory. It is organized by the delegates who are selected by the conferences.

4. The fourth level is the GC. the largest unit of organization that is organized and made up of all unions of the world. Divisions are local sections of the GC for the

\footnotetext{
"Seremh-da! Adrentist Church Manual. 63.

Hitbid.. 309.
} 
designated geographical area. ${ }^{15}$ It is organized by the delegates who are representatives of the world churches.

The GC is the highest authority within the church and manages the system of the world church. ${ }^{16}$ The local churches are the lowest organization in the SDA Church system. The SDA system is unique in comparison to the church system of the three model cell churches. Some of the differences are shown in Table 20.

Table 20. Executive Characteristics of SDA and the Three Cell Churches

\begin{tabular}{|c|c|c|c|c|}
\hline Clause & SDA & GMC & YFGC & OC \\
\hline Denomination & SDA & Baptist & Assembly of God & Presbyterian \\
\hline Executive Style & Centralized & Decentralized & Decentralized & Decentralized \\
\hline $\begin{array}{c}\text { Relationship with } \\
\text { Denomination }\end{array}$ & Dependent & Independent & Independent & Independent \\
\hline
\end{tabular}

After representatives elect the leadership of the local conference, the leadership exercises core administrative business to control personnel management so that the local conference assigns pastors to local churches without any intervention by local churches. The leadership also manages tithes and freewill offerings. The administrative rights of the three churches are characterized as decentralized, contrary to the administrative style of the SDA churches. The political system of the SDA Church in Korea is representative. however the administrative system is a similarly centralized system.

As this table shows, the similar centralized style of the KSDA Church is quite different from that of the model cell churches. With the system of centralization, local

\footnotetext{
${ }^{15}$ Serenth-day Adremist Church Manual. 26.

${ }^{16}$ Ibid.. 65.
} 
KSDA churches are controlled by the local conference and the Union Conference in Korea. Under the KSDA political system. local church ministerial work appears to be passive.

\section{Financial Management}

The KSDA Church acknowledges that the world church is the family of God and. as one unit: It is to enjoy the privileges, to carry the responsibilities, and to follow the procedures of the collective body. This means that the distribution of tithe and freewill offerings is determined by the regulation of the GC. Therefore. every church member is encouraged to give tithe and offerings to the higher level of the church system through a regular channel that consists of churches, conferences, union conferences, divisions of the GC, and the GC. ${ }^{17}$

The policy of the KUC includes financial direction as to how to handle tithe and freewill offerings. The teaching is that "all tithe is a holy matter to be given to God. It must be sent to Conference. Union Conference, and Division without delay. ${ }^{-18}$ Financial regulations, as interpreted by the KUC policy, are shown in Table 21 (below). Some portion of the tithe is given to each level of the church system. ${ }^{19}$

As the Table 21 shows, the local church does not use the tithe. The local conference receives 100 percent of the tithe and uses 66 percent for local pastors ${ }^{*}$ salaries and workers at the local conference. and sends 34 percent to the Union Conference. KUC

\footnotetext{
268.

"Working Policy of Korem Linion Conference of SDA (Seoul: Korean Union Conference. 2008).

"Ibid.. 189.

I"Ibid. 190.
} 
Table 21. Portion of Tithe for Each Level of the SDA Church Organization

\begin{tabular}{|l|c|}
\hline System Level & Portion of Tithe for Each Level of System \\
\hline Local Church & 0 percent \\
\hline Conference & 66 percent \\
\hline Union Conference & 34 percent \\
of Korea & 10 percent for the Union Conference \\
& 10 percent for the retirement program for pastors \\
& 9 percent for the Division \\
& 3 percent for five Conferences \\
& 2 percent for Supporting Budget for \\
& Conferences \\
\hline Northern Asia Pacific Division & 9 percent \\
& 2 percent for the Division \\
& 2 percent for the General Conference \\
\hline General Conference & 2 percent for the General Conference \\
\hline
\end{tabular}

uses 10 percent for pastors and workers of the KUC and reserves 10 percent for pastors retirement programs. Two percent of the tithe is used to support programs for local conferences and 3 percent of the tithe is divided to the five local conferences: The East Central Conference and West Central Conference receive 1 percent of the tithe, based on their conference`s tithe. The other conferences: Southeastern Conference. Midwestern Conference and Southwestem Conference divide the rest of the 3 percent of the tithe that is based on the same ratio as the KUC which sends the rest of the tithe. 9 percent, to Northern Asia Pacific Division (NAPD). The Division uses 7 percent for the workers of the NAPD and sends 2 percent to the GC of SDA's, where it is used for the GC workers. One hundred percent of tithe and special purpose offerings that local church members give must be sent to the local conference. ${ }^{20}$ The local church can use only the 
church budget and other offerings such as church mission offerings, thanksgiving offerings, and relief fund offerings. The ECKC and WCKC were given a special policy regarding the tithe collected in their local churches. They are to give back 5 percent of the tithe for the church ministry. ${ }^{21}$ However. the other three local conferences do not, because of low tithe monies. The financial management system of the Adventist churches and the three model cell churches are described in Table 22.

Table 22. Membership Fee for Conference

\begin{tabular}{|l|l|l|l|l|}
\hline \multicolumn{1}{|c|}{ Clause } & \multicolumn{1}{c|}{ SDA } & GMC & \multicolumn{1}{c|}{ YFGC } & OC \\
\hline $\begin{array}{l}\text { Membership Fee for Higher } \\
\text { Level }\end{array}$ & None & Minimal & Minimal & By Agreement \\
\hline Financial Management & Dependent & Independent & Independent & Independent \\
\hline
\end{tabular}

KSDA churches manage only a part of their financial resources; however, the local conference manages tithe within the system of the centralization.

Contrary to this financial system, the three cell model churches manage all the financial resources and tithe of their churches by themselves independently. The three cell model churches manage the ample financial resources for church ministry directly as the church makes a decision independently. so that those churches quickly re-invest for better ministry of the church. It is an easy system that lets the churches hire more gospel workers and pastors for the church ministry over time. The autonomous political system is very effective for their ministry.

\footnotetext{
${ }^{21}$ A Minute Book. 04-458 (Regulation of Ministry Supporting). The Executive Committee of ECKC made this regulation on November 29. 2004. A Minute Book. 01-86. Executive Committee of WCKC made this regulation on April 11.2001.
} 
Structurally, the system of financial management of the KSDA churches is different from the system of financial management under which the three cell model churches operate. It is a critical barrier to the growth of Adventist churches.

\section{Personnel Management}

As described previously, KSDA churches have four levels of organization. Delegates who are chosen by the churches organize the local conference. Delegates who are chosen by the delegates of the conferences organize the union conference. Delegates chosen by the union conferences organize the Divisions and the GC. ${ }^{22}$ In this process, all church systems are organized according to a prescribed format. After churches organize, the systems of the local church structure become subject to the next level of authority, the higher level organization controls the lower level organization. According to this practice. the executive committee of a local conference makes the decision whether or not to hire a particular pastor and suggests the name to the KUC. The final decision is made by the executive committee of the KUC.

Transfers of pastors within a conference are decided by the local conference. However, a decision for the transfer from one conference to another conference is made through the Union Conference. ${ }^{23}$ With the manner in which the structure is organized. personnel management. selection of the local church pastor or associate pastor is not part of the duties of the local church or its officers. but is decided by the executive committee

\footnotetext{
"Working Policy of Konem Linion Conference of SDA (Secul: Korean Union Conterence. 2007). $73-75$.

?3Ibid.. 108 .
} 
of the local conference. ${ }^{24}$ The KUC and the local conference have the absolute power to manage church pastors and workers, given the current policy for personnel management. This is a major difference from that of the model cell churches where the pastors have the authority to make decisions regarding personnel.

\section{Service Period of the Pastors}

According to the Adventist church records. ${ }^{25}$ there is a difference between the terms of service for the three model cell churches and the SDA Church terms. Table 23 (below) presents the time of service for the pastors working in the three model cell churches.

Table 23. Service Period of the Pastors

\begin{tabular}{|c|l|c|c|c|}
\hline \multirow{2}{*}{ Denomination } & \multicolumn{1}{|c|}{ Church } & Period that Senior & $\begin{array}{c}\text { Number } \\
\text { Pastors Served } \\
\text { of Pastors }\end{array}$ & $\begin{array}{c}\text { Average } \\
\text { Years of } \\
\text { Ministry } \\
\text { per Pastor }\end{array}$ \\
\hline \multirow{2}{*}{$\begin{array}{c}\text { Model Churches: } \\
\text { Non-SDA }\end{array}$} & Global Mission Church & $16(1993-2008)$ & 1 & 16 \\
\cline { 2 - 5 } & Yoido Full Gospel Church & $50(1958-2008)$ & 1 & 50 \\
\cline { 2 - 5 } Onnuri Church & $24(1984-2008)$ & 1 & 24 \\
\hline \multirow{2}{*}{ ECKC of KSDA } & Youngdong Church & $29(1977-2006)$ & 9 & 3 \\
\cline { 2 - 5 } & Mukdong Church & $27(1979-2006)$ & 7 & 4 \\
\hline \multirow{2}{*}{ WCKC of KSDA } & Seoul Joongang Church & $92(1914-2006)$ & 31 & 3 \\
\cline { 2 - 5 } & TaeNeung Church & $16(1989-2005)$ & 2 & 8 \\
\hline
\end{tabular}

${ }^{24}$ Serenth-dal Adrentist Church Manual. 221.

25 The data of SDA churches is collected from Seoul area because the three cell model churches are located around the Secul area. 
In the case of the Seoul Central SDA Church. the pastor has changed thirty-one times in ninety-two years. The average period is 2.96 years. To explore the relationship between church growth and the pastor's term of service, the researcher collected the data for the thirty largest churches in the West Central Korea Conference and the 30 largest churches in the East Central Korea Church. The pastors who worked in the thirty largest churches of West Central Korea Conference were changed on the average of every 3.6 years. ${ }^{26}$ The pastors who worked in the thirty largest churches of East Central Korea Church, were changed on the average of every three vears. ${ }^{27}$ On the other hand, the pastors of the three model cell churches were never changed during their time of service. Rev. Cho finished his ministry of fifty years in YFGC. Rev. Cho has exercised absolute power over his church. On the contrary, KSDA churches experienced many changes of their pastors in a short period.

The different personnel regulations make a big difference between the model cell churches and the Adventist churches. The relationship between the period of ministering and growth is clearly manifested in a study of non-SDA churches. Baek Eunhyung researched twenty-three non-SDA churches that were started between 1975 and 1979 in Songpa-gu in Seoul. The result of the research is shown in Table $24 .^{28}$

The numbers reported in Table 24 show that the pastors who have been in ministry in one church for longer periods have more church members than pastors who

\footnotetext{
?"Kang. 21-660.

"YoungJoon Im. Histon of East Central Korean Conference of Serenth-da! Adrentists (Seoul: SamYoung. 2007).

"Younggi Hong. Norean Mega-Charches and Charismatic Leadership (Seoul: Church Growth Institute. 2002). 87-88.
} 
Table 24. Length of Service of the Pastor and Membership Numbers

\begin{tabular}{|l|l|l|l|l|}
\hline Pastoral Changes & 1 time & 2 times & 3 times & 5 times \\
\hline Average Attendees & 1.232 & 953 & 195 & 143 \\
\hline Churches & 14 & 4 & 2 & 3 \\
\hline
\end{tabular}

have been serving for shorter periods in the church. For example, one church pastor served the one church for over thirty years and over that time period. the average membership was $3.621 .^{29}$

\section{Summary}

This chapter identified the different components of the SDA Church system and compared a few of the aspects with the three model cell churches. The differences between the KKSDA churches and the three model cell churches included factors that might help the cell church groups experience successful growth within the Adventist church system. The following is a summary of some of the findings:

First, both the model cell churches and the KSDA churches have manuals for cell group ministry, but the Adventist system is not as organized or as directive.

Second, the model cell churches have a standard systematic process model, but the KSDA churches have no standard systematic group model.

Third. cell groups are central to the model cell churches, while the KSDA churches have no cell groups integrated into the central ministry of the church.

\footnotetext{
"Hong. Korean Mega-Churches and Charismatic Le'adership. 87-88.
} 
Fourth, cell group ministry is integrated into all departments of the model cell churches, but the KSDA churches treat cell group ministry as a part of the Mission Department. among many other church departments.

Fifth. cell groups function independently under the model cell church system, but the KSDA churches are linked with higher levels. such as conferences and a Union Conference similar to a centralized system. Thus, the cell ministries are also politically dependent.

Sixth, cell group churches manage their finances independently, but the KSDA churches do not manage tithes and offerings locally. The tithe is controlled by higher levels. such as Conferences. Union Conference, and GC.

Seventh, cell group churches control personnel issues, but local KSDA churches do not manage personnel; personnel are managed directly by the conferences, Union Conference, and GC.

Eighth, pastors in cell group churches tend to stay in one place while the tenure of the pastors in the KSDA churches is very short. three to four years.

Reconsidering the place of cell groups and how they function within the SDA Church system as compared to the three model cell churches would help leaders in the Adventist Church make decisions as how best to incorporate cell ministry into the evangelistic mission and vision of the church in South Korea within the policies of the SDA Church. 


\section{CHAPTER 8}

\section{SUMMARY, CONCLUSIONS, AND RECOMMENDATIONS}

In this chapter, the main findings of the study are summarized: conclusions are presented and recommendations given to the leaders of the Seventh-day Adventist Church in South Korea.

\section{Summary}

This study can be summarized as follows:

1. The strategy of incorporating cell group ministries that the cell group churches use as an evangelistic tool have proven successful in a variety of settings worldwide is a practical approach to ministry and has been used successfully to increase membership. The cell meetings in homes have proven to be a successful response to the problems in traditional churches: space, multiplication of membership. fellowship for existing members. support for new members, discipling, etc.

2. Cell group ministry is identified as a very useful and strategic ministry in that a prototype of cell group ministry is found in the Bible record and that small group ministry is found in the concepts of Ellen G. White's writings.

3. The strategy of cell group ministry as a small group form fits with the Korean culture. with its religious background that has prepared them to accept God. and also with the modern circumstances of Korea. 
4. The GMC, the YFGC, and the OC adopted the cell group ministry into their church system and have had success in establishing cell group ministries. These churches organized cell ministry as a central system for their evangelism. and as a base for all of their departments. All of the administrative systems support cell group ministry through the various channels.

5. The pastors who founded the GMC, the YFGC. and the OC have a strong conviction about cell group ministry as a powerful tool and made it a core ministerial strategy for success in their churches.

6. In comparing the KSDA churches with the three cell model churches, many different factors in the system, structure, and practice were found. The key differences between them were identified as follows:

First. the small groups or cell groups of the KSDA churches do not function in the same manner as the other three churches.

Second. the political organization of the KSDA Church is strongly linked with the four levels of the church system, unlike the model cell churches that are linked to their higher organization level, but function independently.

Third, the departmental system of the KSDA churches places the cell group ministry or small group ministry in a minor ministry position under the Mission Department. On the contrary, the cell model churches have the cell group ministry as the main base and structure of their church ministries.

Fourth. related to the second factor. SDA conferences exercise a powerful administrative decision-making control over local churches in personal management. unlike any of the model cell churches. 
Fifth, also related to the second factor, SDA conferences receive tithe and special purpose offerings from the local churches. They have executive power over the budget, contrary to the three cell model churches.

Sixth, regarding structural decisions, the tenure of pastors is decided by conferences without input from the local church pastors and local church representatives. On the contrary. the pastors serving the three model cell churches exercise executive rights in the selection of individuals for pastoral position in the respective churches. Thus, some KSDA Church pastors experience a very short tenure of ministry in the church. Seventh, related to the second and sixth factors, the pastors do not choose a location for their ministry, and the local churches have no right to invite a particular pastor to serve their church. On the contrary, the pastors of the three model cell churches exercise that right by themselves.

\section{Conclusions}

The objective of this dissertation was to explore and identify the factors contributing to the success of the three fastest growing cell churches in South Korea. The study compared the system. structure. and practice of the KSDA. as it relates to small group and cell ministries. According to the findings that were revealed through this study, the KSDA churches differ in many aspects from the three cell model churches. Overall, the research identified several critical factors that the leaders of the KSDA churches need to consider as they seek to revise the cell group strategies.

The following are the main conclusions of this study. The three model churches successfully followed similar cell systems, while the KSDA Church system differed widely and did not have success. Further study may be needed to explore how to more 
efficiently incorporate cell groups into the KSDA Church.

1. The study has shown that the three model cell churches established the cell group ministry system as the basis for all their ministries. On the contrary. the KSDA churches maintained the cell ministries as a minor part of their church structure. under the Church Ministry Department. Perhaps, the KSDA churches would experience greater success if the cell ministry were to become more central to the outreach programs of the church.

2. The study has shown that the three model cell churches are linked to a higher organization, but function independently. The KSDA Church has a different system. Perhaps study should be given as to how to empower the various ministries at the local church levels, given the current system.

3. The study has shown that the three cell model churches managed 100 percent of their tithe and offerings, contrary to the system of the KSDA churches. where the conferences receive 100 percent of the tithe and special purpose offerings. This is currently a hindrance to the establishment of cell groups. A solution needs to be found that will allow more funding for the local church programs, such as cell group ministry.

4. The study has shown that personnel issues in the three model cell churches are managed by the pastor and the local church. On the contrary, the conferences in the Korean Union Conference make decisions regarding personnel for the local KSDA churches. It would allow more freedom to operate the church, if the local church pastors and the church community could have input in personnel matters. especially prior to the selection or transfer of a pastor.

5. Related to the fifth finding. the study has shown that the tenure of the pastors in 
the three model cell churches is long enough to enable the pastors to succeed in cell group ministry. On the contrary, the tenure of the KSDA church pastors is too short to develop a cell group system in the local church. The KSDA conferences may need to consider longer tenures for pastors.

\section{Recommendations}

On the basis of the research, specific recommendations now follow for the leaders of the KSDA churches. These recommendations are shared with the trust that the suggestion will help the leaders establish a new paradigm in which the cell church ministry can function successfully.

To the Local Church Pastors

1. The local church pastors should establish cell group ministry central to its ministry in order to overcome some of the difficult situations facing growth and vitality of the Church in South Korea.

2. Korean society would respond favorably to the cell group ministry system. The culture is losing the strength of the community-oriented Korean life style and the small group format in the church would appeal to the public.

3. Training is needed for the cell group leaders according to certain levels, such as the following: cell group $\rightarrow$ district cell group $\rightarrow$ parish cell group.

4. Make a church yearly program to help the cell group ministry to function successfully. 
To the Local Conference Leaders

5. The conference leaders need to recognize the need of funding for the local church cell ministry.

6. As the research has shown, the tenure of the pastors is too short to successfully set up a sustainable cell group ministry. Regarding the length of the term of service, it might be good for the conference leaders to consider allowing the local pastor to stay longer than what is now the practice, because short-term ministry is a critical barrier to cell church building.

7. The local conferences need to train the local church pastors and cell leaders.

8. There is a need for the local conference to encourage the local leaders to cooperate together to establish cell groups

To the Union Conference Leaders

1. Based on this study of the system of KSDA churches, it is recommended that the leaders of the KUC should support the building of cell group ministries in the five local conferences.

2. Related to the first recommendation. the KUC should develop a unified system of cell group ministry for the five conferences in Korea. because the five conferences are geographically located in the same territory on the Korean peninsula.

3. Related to the first recommendation, the KUC should prepare and provide materials. such as books. paper printouts, documents, and charts needed for the active cell groups: information and guidelines for setting up the cell structure, regulations for operating the system, guidelines for leaders, forms for reporting. etc.

4. The following should be shared by the KUC with local conferences: (a) a 
taxonomy for the training program for new church members, members, cell group leaders, and pastors: (b) a tailor-made program for establishing cell group evangelism, customized to meet the needs of the local community; (c) a standard system of cell church ministry for local churches. conferences. and the Union Conference; (d) monetary support and/or some strategy that would encourage the local churches and pastors to develop cell groups. train for discipleship, and increase the membership within the policies of the KUC: and (e) a paradigm shift of cell church ministry should be made and begun by the leaders of the KUC.

\section{Recommendation for Further Studies}

The purpose of this descriptive qualitative study was to explore the qualities that characterize the three model cell churches in South Korea and to identify the differences between these growing churches and the KSDA churches. This is a pilot study in this field in Korea. However, further research should be done to explore practical strategies for implementing the factors that contribute to the successful operation of cell ministries. 


\section{APPENDIX A}

\section{MAP OF THE REPUBLIC OF KOREA}

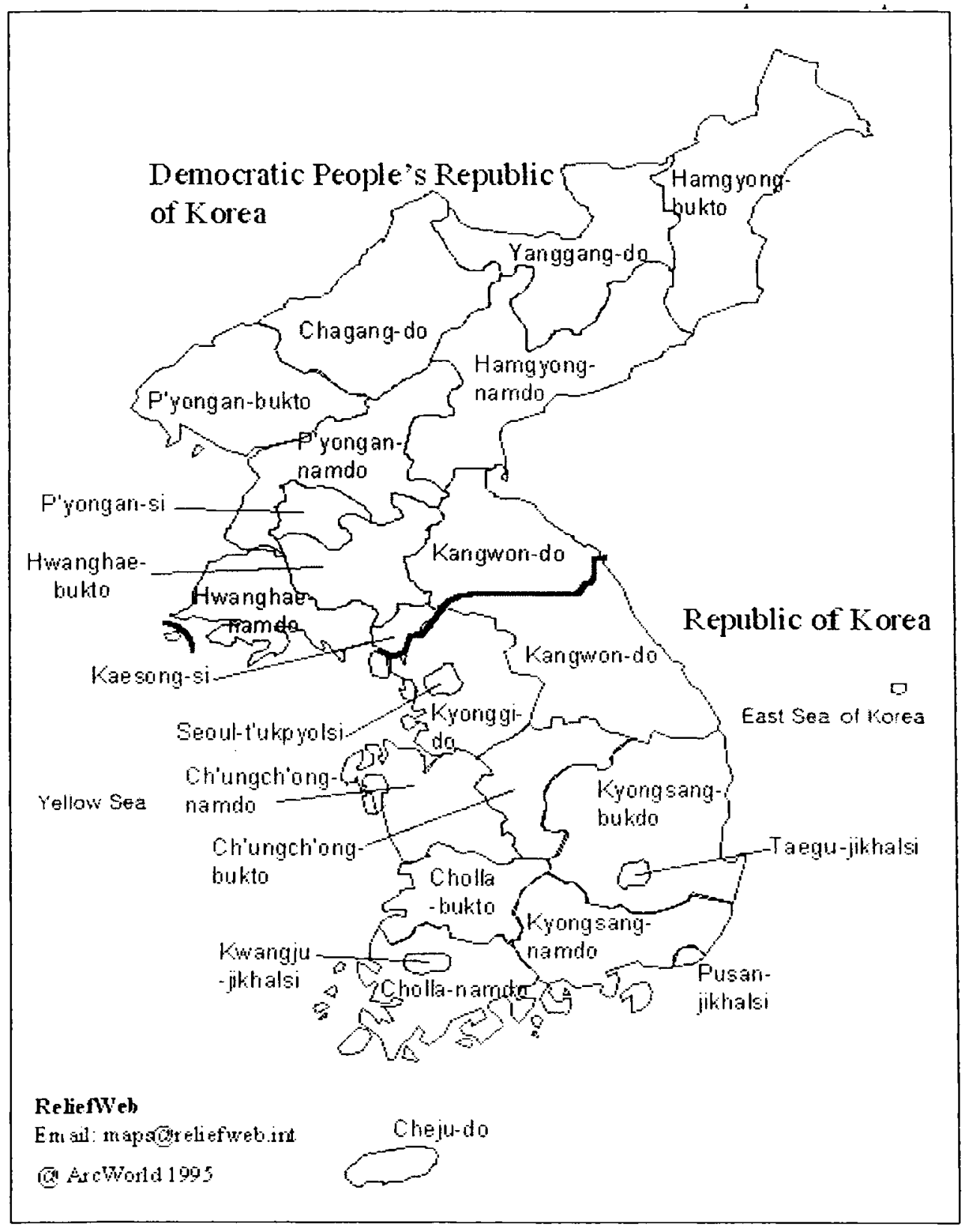

Source: "Korean Peninsula: Provinces." http:/www.reliefweb.int/mapc 
asi_east/reg/korea_ad.gif (accessed by December 1, 2009). 


\section{BIBLIOGRAPHY}

Allthatnew's. "Korean Assemblies of God." http://www.allthatnews.co.kr/news/ quickViewArticleView.html?idxno=7539 (accessed May 7, 2008).

The American Heritage Dictionary of the English Language. Edited by William Morris. Boston: Houghton Mifflin. 1976. S.v. "group." Quoted in Arthur D. Jensen and Joseph C. Chilberg, Small Group Communication. Belmont, CA: Wadsworth. 1991.

The American Heritage Dictionary of the English Language. Edited by William Morris. Boston: Houghton Mifflin, 1992. S.v. "cell."

Anderson. Godfrey T. Outriders of the Apocalypse. Mountain View, CA: Pacific Press. 1972.

Ankerberg. John. "Shamanism." Ankerberg Theological Research Institute. http://www: johnankerberg.org/Articles/new-age/NA0801 W3.htm (accessed July 14, 2009).

Amold, Jeffrey. The Big Book on Small Groups. Downers Grove, IL: InterVarsity Press, 2004.

Bacchiocchi. Samuele. Women in the Church. Berrien Springs, MI: Biblical Perspectives, 1987.

Banks, Robert, and Julia Banks. The Church Comes Home. Peabody, MA: Hendrickson, 1998.

Bankston, Carl L. Ill. “Communities." Encyclopedia of Family Life. Salem Press, 1999. $1: 286$.

Barker. William P. Women and the Liberator. Old Tappan. NJ: Revell, 1972.

Barrett. Lois. Building the House Church. Scottdale. PA: Herald, 1986.

Bauckham. Richard. Gospel Women. Grand Rapids, MI: Eerdmans, 2002.

Beckham. William A. Redefining Revival: Biblical Patterns for Missions, Evangelism and Growth. Houston. TX: Touch. 2000.

Birkey, Del. The House Church. Scottsdale. PA: Herald, 1988. 
Bowen. Roger. So I Send You. London: SPCK. 1996.

Branick. Vincent. The House Church in the Writings of Paul. Wilmington, DE: Michael Glazier, 1989.

Bunge, Fredrica M.. ed. South Korea: A Country Sudy. Washington, DC: American University Press, 1982.

Cell Leader Intern Guidebook. Houston. TX: Touch. 1995.

Chae, Kyung-Oh. Thought of Religion: Handbook of Korea. New York: Pageant, 1958.

Chang. Heeyoul. Constitution. Seoul: Publishing Department of Christianity Korean Assemblies of God. 2007.

Cheong, Ok-Ja. ed. "Korean Confucianism and Conduct of State Affairs." In Special Lecture on Korean History. Edited by The Compilation Committee of a Special Lecture on Korean History. 358. Seoul: Seoul University Press, 1991.

Cho. Paul Yonggi. Cell Group Worship Lesson Studv. Seoul: Seoul Malsumsa, 2008. Hope Ministry 45 Years. Seoul: Institute of Church Growth, 2007. 1981.

. Successful Home Cell Groups. Seoul, Korea: Church Growth International, Successful Home Cell Groups. Seoul: Seoul Logos. 1997.

Choi, Junsick. Reading Korean Religion as a Culture. Seoul: SaGeo Public Center, 1998.

Christensen, Karen, and David Levinson. "What is Community." Encyclopedia of Community from the Village to the Virtual World. 2003. 1:xxxvii.

Christianity Korean Baptist Church. "Church Bulletin of Global Mission Church." April 27. 2008 .

Christianity Korean Baptist Convention. "Report of Christianity-Korean Baptist Convention." September 2007.

Christianity Today. "Soon System of Onnuri Church." http://www.chtoday.co.kr view.htm? code=\&id=152012\&orderby=no (accessed July 14, 2008).

Coleman. Robert E. The Master Plan of Erangelism. Grand Rapids. MI: Spire. 1994.

Comiskey. Joel. Cell Church Solutions: Transforming the Church in North America. Moreno Valley, CA: CCS, 2005. 
. From 12 10 3: How to Apply G-12 Principles in Your Church. Houston, TX:

Touch. 2003.

. Home Cell Group Explosion. Houston. TX: Touch, 1998.

. Leadership Explosion. Houston. TX: Touch, 2000.

The Compilation Committee of a Special Lecture on Korean History, ed. Special Lecture on Korean Historn. Seoul: Seoul University Press. 1991.

Constitution of Christianity Korean Assemblies of God. Seoul: Publishing Department of Christianity Korean Assemblies of God. 2007. Vol. 3, Chap. 6, Art. 38.

Cox. David. Future Church. Alma Park, Grantham. Linces.. England: Stanborough Press, 2001.

. Think Small Groups. Alma Park. Grantham. Lincs, England: The Stanborough Press, 1998.

DangDangNews. "Salary of Somang Church." Gyuhock Hwang's Ecclesian News. http://ww'w.dangdangnews.com/news/articleView.html?idxno=3403 (accessed June 3, 2008).

Data Room of Crossmap. "History of Korean Presbyterian Church." http:// crossmap. christiantoday.co.kr/data/bbs/zboard.php?id=data_theology\&page $=1 \& \operatorname{sn} 1=\&$ divp age $=1 \& \mathrm{sn}=$ off $\& \mathrm{ss}=$ on $\& \mathrm{sc}=$ on $\&$ select_arrange $=$ headnum $\&$ des $c=\mathrm{asc} \& \mathrm{no}=1203$ (accessed August 21, 2008).

Davis, Deena. Discipleship Journal's I0I Best Small-Group Ideas. Colorado Springs, CO: NavPress Publishing Group. 1996.

Denominational Year Book. "Birth of Korean Assemblies of God." http://www.ag. or.kr/history/history2-5.html (accessed May 7, 2008).

The Editorial Office. Jungseon Myeongsimbokam. Seoul: Dong Hwa Sa. 1970.

Evans, Mary J. Women in the Bible. Downers Grove. IL: InterVarsity, 1983.

Fernandez. Gil G.. ed. Light Dawns orer Asia: Adventism 's Story in the Far Eastern Division. Silang. Cavite, Philippines: Adventist International Institute of Advanced Studies Publications, 1990.

Finger, Reta Halteman. A Simulation Paul and the Roman House Churches. Scottsdale. PA: Herald. 1993.

Finnell, David L. Life in His Bodr. Houston. TX: Touch. 1995. 
Gale. James S. Korea in Transition. New York: Laymen`s Missionary Movement, 1909.

Global Ministerial Leadership Institute. For New Community. Daejon: Segee, 2007.

Global Mission Church. "Formation of Cell Church." http://cell.jiguchon.org/html/ cell_format3.asp (accessed May 6, 2008).

. "Global Mission Church of the Healing of Nation and Changing of the World." May 2007, 6, 7.

. I Want to Know the Global Mission Church. 4th ed. Seoul: Global Mission Church. 2007.

. "Ministerial Function of Cell Church." http://www.jiguchon.org /home.asp (accessed July 20. 2008).

. "Ministerial Structure of Cell Church." http://www.jiguchon.org/gmc_cell/ cell_adult l.asp (accessed May 6.2008).

. "Notice of Online Offerings." Financial Department.

http://www.jiguchon .org/home.asp (accessed July 20, 2008).

. "Organization Chart of Ministry." http://www.jiguchon.org/gmc_m/ mission_organization.asp (accessed May, 06, 2008).

. "QA for Cell Group Ministry." Ministry of Cell Group Church.

http://cell .jiguchon.org/html/cell_faq.asp (accessed May 06, 2008).

. Shepherd's Guidebook for 2008.

. “Supporting Ministry for Cell Group." http://cell.jiguchon.org/html/

cell_support.asp (accessed May 6, 2008).

. "Transition of Increase and Decrease of Cell Groups."

http://cell.jiguchon .org/html/cell_feature.asp (accessed May 6, 2008).

."Vision of Jiguchon Church in the 21 st Century: Strategy."

http://www jiguchon.org/english/html/vision.asp (accessed May 5, 2008).

Green, Michael. ed. Church Without Walls. Waynesboro, GA: Paternoster, 2002.

Greenleaf, Robert K. The Servant as Leader. Indianapolis, IN: The Robert K. Greenleaf Center. 1991.

Ha, Yongjo. Dreaming Acts Church. Seoul: Durano. 2008. 
A Handbook of Korea. 9th ed. Seoul: Korean Overseas Information Service, 1993.

History of Korean Adventist Church. "Beginning of Korean Adventist Church." http:"'www.adventistkr.org/si_intro_pages/c_a.html (accessed September 18, 2008).

Hong. Younggi. Generative Power to Grow: Yoido Full Gospel Church. Seoul: Institute of Church Growth, 2008.

. Korean Mega-Churches and Charismatic Leadership. Seoul: Church Growth Institute, 2002.

. Rev: David Cho s Leadership. Seoul: Institute of Church Growth, 2005.

Hongrae, Park. Cell Group Cell Church. Seoul: Love Each Other. 2003.

Hurston, Karen. Breakthrough Cell Groups. Houston, TX: Touch, 2001.

Hyldahl, Niels. The History of Early Christianity. New York: Peter Lang. 1997.

Icenogle, Garth Weldon. Biblical Foundations for Small Group Ministry. Downers Grove. IL: InterVarsity, 1994.

Im, YoungJoon. History of East Central Korean Conference of Seventh-day Adventists. Seoul: SamYoung. 2007.

International Theological Institute, ed. Yoido Full Gospel Church 1998-1999. Seoul: Seoul Malsemsa. 1998.

James. Donald. "Mankind is Created for Community." In Cell Intensive I. Berrien Springs, MI: North American Division Evangelism Institute.

Jensen. Arthur D., and Joseph C. Chilberg. Small Group Communication. Belmont, CA: Wadsworth, 1991.

Joins News Paper. "Statistical Data of Korean Religion." http://cafe.joins.com/adams/ 436683 (accessed September 13, 2007).

Jung, Byungkwan. World 17: Mega Church to Lead a Rerolution of Gospel. Seoul: Word of Life Co., 2007.

Kang. Seokwoo. Church History of West Central Korean Conference of Seventh-day Adventists. Seoul: DuGyeong. 2008. 
Karkkainen, Veli-Matti. An Introduction to Ecclesiology. Downers Grove, IL: InterVarsity, 2002.

Kemp, C. Gratton. Small Groups and Self-Renewal. Columbus, OH: Seabury, 1972.

Ken, Mitsui. "The Study of the Comparison between Korean and Japanese Protestant Church Growth." MA dissertation. Seoul National University, 2000.

Kim. Byungseo. Korean Society and Protestant. Seoul: Bookcenter HanU1, 1995.

. "A Sociological Understanding on Korean Church Phenomenon." Theological Thoughts 36 (1982): 711 .

Kim. Myung-Hyuk. "Historical Analysis of Ancestor Worship in the Korean Church." In Christian Alternatives to Ancestor Practices, edited by Bong-Rin Ro, 164-177.

Taiwan: Asia Theological Association, 1985.

Kim. Seongkuk, Kibok Beak, and Yeon Choi. CEO Yonggi Cho. Seoul: Institute of the Church Growth, 2007.

Kim, Sung-Tae. "Contextualization and Presbyterian Church in Korea." (PhD dissertation, Fuller Theological Seminary. 1991.

Kim, Ui-Hwan. Biblical Vicw of Blessing. Seoul: Sung Kwang, 1982.

Kim, Young Bin. "Pastor Yonggi Cho: 'I Am Not a Supporter of Big Churches.".

Christian Today. http://www.chtoday.co.kr/view.htm?code=pd\&id=155077 (accessed May 8, 2008).

King, Hans. The Church. New' York: Sheed and Ward, 1967.

Ko, Young. "Korean Ancestor Worship in the Light of Biblical Teachings." DMin dissertation, Adventist International Institute of Advanced Studies, 1992.

Kongbobu, Munhwa, ed. Religion of Korea. Seoul: Munhwa Kongbobu, 1989.

Korean Assemblies of God. "Birth of Korean Assemblies of God." http://www.ag.or.kr/ history/history2-5.html (accessed May 7, 2008).

.Due Fee." http://www.ag.or.kr/ (accessed November 4, 2008).

. "Establishment of Seobinggo Church of the First Pentecostal Church." http:i/www.ag.or.kr' (accessed November 4. 2008).

. "Introduction of Constitution of the Church." http://www.kihasung.org' (accessed May 13, 2009). 
Korean National Statistical Office. "2002 Statistics.” http://www.nso.go.kr/eng2002/ (accessed July 14, 2002).

"Korean Peninsula: Provinces," http://www.reliefweb.int/mapc/asi_east/reg/korea_ad.gif (accessed by December 1. 2009).

Korean Seventh-day Adrentist Y'carbook. Seoul: Signs of the Times, 2009.

Korean Union Conference Yearbook. Seoul: Signs of the Times, 2008.

Kreider, Larry. House to House. Houston, TX: Touch, 1995.

Kubo, Sakae. The God of Relationships. Hagerstown. MD: Review and Herald, 1993.

Kweon, Hyuckwoo. Church Hisiory of ECKC of SDA. Seoul: Samyoung, 2007.

Lee, Daniel Dongwon. Grecn Pasture that We Long For. Seoul: Durano. 2007. . Leading Principle for the Cell Church Mecting. Taejon: Global Ministerial Leadership Institute, 2007.

Lee, Neung-Hwa. Shamanism of Yi Dinasty. Seoul. Korea: The Institute of Korean Cultural Anthropology, 1968.

Lee, Sangsoo. Healthful Church Growth Now: It is Sistem. Seoul: Word of Life, 2005. Strategy for Church Growth. Seoul: Word of Life, 2006.

Lee, Tae Hyung. "Pastor Younghoon Lee." Yoido Full Gospel Church. http://yfgc.fgtv.com/Y15/WY15_7_view.asp?num=2\&vnum=2\&PAGE=4 (accessed May 3, 2009).

Lee, Yung Lin. History of Korean SDA Church. Seoul: Sun Myung Cultural Press, 1968.

Leonard, Bill J. The Nature of the Church. Layman's Library of Christian Doctrine. Nashville, TN: Broadman. 1986.

Lunny, William J. The Jesus Option. New York: Paulist, 1994.

Mallison, John. Growing Christians in Small Groups. Sydney, Australia: Scripture Union Books. 1989.

Min. Kyung-Bae. Church and People. Seoul: Korean Christian Press, 1981. 
"The Ministry of Culture and Information." In Religion of Korea. Edited by Munhwa Kongbobu. 121. Seoul: Munhwa Kongbobu, 1989.

Missionmagazine. "2005 State of the Presbyterian Church." http://missionmagazine. com/main/php/search_view.php?idx=365 (accessed August 21, 2008).

Moon, Sang-Hee. "Shamanism and the Korean Church." Saesaengm?ung (July 1969): 25-26.

Neighbour, Ralph W. The Shepherd's Guidebook. Houston. TX: Touch Pul ication, 1996. . Where Do We Go firom Here? Houston, TX: Touch. 2000.

Neumann, Mike. Home Groups for Lrban Cultures. Pasadena. CA: William Carey Center, 1993.

Oh My News International. "Korea, Last Year"s Export Ranked 11 th in the World ... 1 Step Up." http:/english.ohmynews.com/articleview/article_view.asp? no $=352577 \&$ rel_no=1 (accessed May 30, 2008).

Onnuri Church. "The Church that Onnuri Dreams." http://ww'w.onnuri.or.kr/ sub.asp?gubun=2102 (accessed August 22, 2008).

. "Fostering Ministry." http://www.onnuri.or.kr/sub.asp?gubun=3106 (accessed August 24. 2008).

. "Fostering Ministry System of Onnury Church." http:/file.cgntv.net/ sub.asp? mode $=$ view $\&$ id $x=452 \&$ gubun $=0601 \&$ gotopage $=3 \&$ Search_type $=\&$ search_andOr $=\&$ search_Keyword $=\&$ sort_num $=1$ (accessed August 24, 2008).

. "History of Onnuri Church." http://www.onnuri.or.kr/ sub.asp?gubun=2104 (accessed August 21, 2008).

. "Introduction of the Church." http://www.onnuri.or.kri sub.asp?gubun=2101 (accessed August 19, 2008).

. "Ministry of Next Generation." http://www.onnuri.or.kr/sub.asp?gubun=2902 (accessed August 26. 2008).

. "Program of 10,000 Soon Group Leader." http://file.cgntv.net/ sub.asp? gubun $=0606$ (accessed August 26, 2008).

Park. Geon C. Cartoon Korean History. Hurst, TX: J \& S, 1999. 
Park, Ȳoung-Jie. "Contemporary Missiology and Ecclesiological Praxis: An Analysis of Church Growth in Korea." DMin dissertation, Eastern Baptist Theological Seminary, 1984.

Ro, Bong-Rin, ed. Christian Alternatives 10 Ancestor Practices. Taiwan: Asia Theological Association, 1985.

Ryu. Tong-Shik. The Christian Faith Encounters the Religions of Korea. Seoul: The Christian Literature Society of Korea. 1965.

Seventh-dav Adventist Church Manual: Korean Union Conference. Seoul: Signs of the Times, 2008.

Shin, Hogyun. "An Exploratory Approach on the Realities and Breakthroughs of Korean Church Polarization." A Study of Logos Management 5. no. 1 (2007): 1-19.

Stanton. G. N. Jesus of Nazareth in New Testament Preaching. London: Cambridge University Press, 1974.

Stevens, R. Paul, and Phil Collins. The Equipping Pastor. New York: Alban Institute, 1993.

Stockstill, Larry. The Cell Church. Grand Rapids, MI: Zondervan. 1998.

Strommen, Merton B. The Innorative Church. Minneapolis, MN: Augsburg, 1997, 142143. Quoted in David Cox. Future Church. Alma Park, Grantham, Lincs, England: Stanborough Press, 2001.

Sweet, Leonard. Quantum Spirituality:A Postmodern Apologetic. Dayton. OH: Whaleprints, 1991.

Thurian, Max. Priesthood and Ministry. Translated by Paula Clifford. Oxford: Mowbray, 1983.

Tubbs, Stewart L. A Systems Approach to Small Group Interaction in Christian Perspectives on Sociology: Grand Rapids, MI: Zondervan, 1982. 152. Quoted in Del Birkey, The House Church. Scottsdale, PA: Herald. 1988.

White, Ellen G. An Appeal for Self-Supporting Laborer. Nashville, TN: Associated Lecturers` Bureau, 1933.

. Child Guidance. Washington. DC: Review and Herald, 1954.

. Christian Experience and Teachings of Ellen G. White. Mountain View. CA:

Pacific Press, 1922. 
- Counsels for the Church. Nampa, ID: Pacific Press. 1991.

. Counsels on Diet and Foods. Washington, DC: Review and Herald, 1976.

. The Ellen G. White 1888 Materials. Washington. DC: Ellen G. White Estate, 1987.

. Erangelism. Washington. DC: Review and Herald. 1970.

. Gospel Workers. Washington. DC: Review and Herald. 1948.

Instruction for Effective Christian Service. Hagerstown, MD: Review and Herald. 1947.

. "Laborers Together with God." Review and Herald, 24 August 1886, 529-530.

. Life Sketches of Ellen G. White. Mountain View, CA: Pacific Press, 1915.

Ellen G. White Writings Complete Published. 2007 ed. CD-ROM. Ellen G. White Estate, 2007.

. Life Sketches of James White and Ellen G. White. Battle Creek, MI: Seventhday Adventist Publishing Association. 1880.

. Loma Linda Messages. Elmshaven. Sanitarium, CA, 1906. Ellen G. White Writings Complete Published. 2007 ed. CD-ROM. Ellen G. White Estate, 2007.

. Manuscript Releases. 21 vols. Silver Spring. MD: Ellen G. White Estate, 1990.

The Ministry of Healing. Mountain View, CA: Pacific Press, 1942. Ellen G. White Writings: Comprehensive Research. 2008 ed. CD-ROM. Ellen G. White Estate, 2008.

. Notebook Leaflets from the Elmshaven Libran. Payson. AZ: Leaves-OfAutumn Books. 1985.

."Parentage and Early Life." Signs of the Times, 6 January 1876. Ellen G.

White Writings Complete Published. 2007 ed. CD-ROM. Ellen G. White Estate, 2007.

. "A Risen Saviour." The General Conference Bulletin, 24 May 1909. 14-15.

. "Second Reading." Supplement to Review and Herald, 21 June 1898. Ellen G. White Writings Complete Published. 2007 ed. CD-ROM. Ellen G. White Estate, 2007.

. Testimonies for the Church. 9 vols. Mountain View, CA: Pacific Press. 1948. 
. "To Every Man His Work." Australasian Union Conference Record, 25

February 1907, 1.

Welfare Ministry. Washington. DC: Review and Herald, 1952.

Wikipedia. "Yoido Full Gospel Church." http:/en.wikipedia.org/wiki/Yoido_Full_ Gospel_Church (accessed October 31.2008).

Wikipedia (Korean). "Presbyterian Church."

http://ko.wikipedia.org/wiki $\%$ EC \%9E\%A5\%EB\%A $\% 9$ C $\%$ EA\%B5\%90 (accessed August 21, 2008).

Wilkins, Michael J. Following the Master: A Biblical Theology of Discipleship. Grand Rapids, Ml: Zondervan. 1992.

. In His Image: Reflecting Christ in Everyday Life. (Colorado Springs, CO: NavPress. 1997.

Witherington, Ben III. Women in the Ministrv of Jesus: A Study of Jesus 's Attitude to Women and Their Roles as Reflected in His Earthly Life. Cambridge: University Press, 1984, 4-8. Quoted in Sakae Kubo. The God of Relationships. Hagerstown, MD: Review and Herald, 1993.

Working Policy of Korean Union Conference of SDA. Seoul: Korean Union Conference, 2007.

Working Policy of Korean Union Conference of SDA. Seoul: Korean Union Conference, 2008.

Yahoo Korea. "2006 Personage of Religion World." http://kr.blog.yahoo.com/ lodemtrees/4803 (accessed July 14, 2008).

Yoido Full Gospel Church. "Evangelism Department of New Church Members." http://yfgc.fgtv.com/common_js/openwindow.asp?IFrameSrc=http://nfamily.fgtv. $\mathrm{com} /$ (accessed August 15. 2008).

. "Ministry Department." http://yfgc.fgtv.com $/$ 666/WY6_3.asp (accessed November 2. 2008).

You, Dongsick. Christianity and Korean History: Seoul: Yeonsei University Press, 1997. . Religion of Korean and Christianity: Seoul: SamSung Press Center, 1986.

Yun, Yihum. Religious View of Korean. Seoul: Seoul University Press, 2001. 
Zehr, Paul M., and̄ Jim Egli. Alternative Models of Mennonite Pastoral Formation. Elkhart, IN: Institute of Mennonite Studies, 1992. 
VITA

Name: Won Moo Song

Country of Origin: South Korea

\section{Academics:}

2010 DMin (Cell Church Ministry)

Andrews Theological Seminary, USA

1989 MPTh (Master of Pastoral Theology)

Institute of Adventist Advanced Seminary. Philippines

1988 BA (Theology)

Shamyook University. South Korea

\section{Experience:}

2006-Present Pastor, Uiseong Church, Southeast Conference, South Korea

2004-2006 Pastor, Dallas Forth Worth Korean Church, Texas, USA

2001-2002 Volunteer Pastor, Kallamazoo Korean Group, Michigan, USA

1998-2001 President, Russian Shamyook University, Russia

1996-1997 Planner, Russian Shamyook University. Russia

1992-1996 Pastor, Pusan Pukboo Church, Southeast Conference. Korea

1989-1992 Pastor, Seongbuk Church, Southeast Conference, Korea

1984-1995 Layman Pastor, Koseong Church, Korea

1982-1983 Layman Pastor, Daegu Bukboo Church, Southeast Conference. Korea

1979-1981 Layman Pastor. Hoopyung Church. Southeast Conference. Korea

1975-1980 Colporteur, Southeast Conference. Korea 